\title{
LENITA CAMARGO VERDURICO
}

Efeito da suplementação prolongada de ácidos graxos insaturados na alimentação de novilhas Bos taurus sobre a qualidade oocitária e embrionária e perfil metabólico

\section{Pirassununga}

2015 


\section{LENITA CAMARGO VERDURICO}

\section{Efeito da suplementação prolongada de ácidos graxos insaturados na}

alimentação de novilhas Bos taurus sobre a qualidade oocitária e embrionária e perfil metabólico

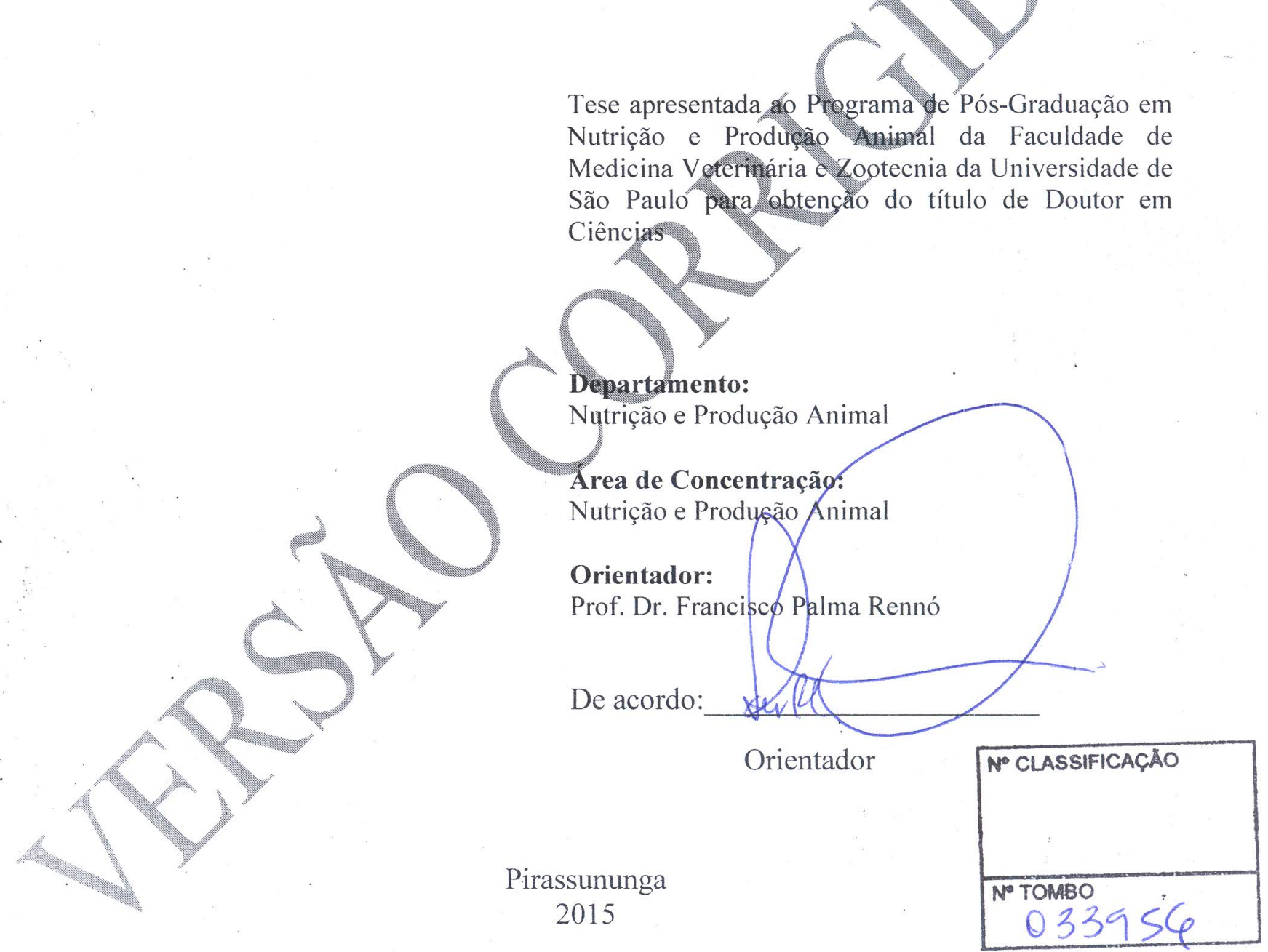

Obs: A versão original se encontra disponível na Biblioteca da I MVZ/USP 


\section{LENITA CAMARGO VERDURICO}

Efeito da suplementação prolongada de ácidos graxos insaturados na alimentação de novilhas Bos taurus sobre a qualidade oocitária e embrionária e perfil metabólico

Tese apresentada ao Programa de PósGraduação em Nutrição e Produção Animal da Faculdade de Medicina Veterinária e Zootecnia da Universidade de São Paulo para obtenção do título de Doutor em Ciências

\section{Departamento:}

Nutrição e Produção Animal

Área de Concentração:

Nutrição e Produção Animal

Orientador:

Prof. Dr. Francisco Palma Rennó

\section{Pirassununga}




\section{FOLHA DE AVALIAÇÃO}

\section{Nome: VERDURICO, Lenita Camargo}

TÍTULO: Efeito da suplementação prolongada de ácidos graxos insaturados na alimentação de novilhas Bos taurus sobre a qualidade oocitária e embrionária e perfil metabólico

Tese apresentada ao Programa de Pós-Graduação em Nutrição e Produção Animal da Faculdade de Medicina Veterinária e Zootecnia da Universidade de São Paulo para obtenção do título de Doutor em Ciências

Data:

\section{Banca Examinadora}

Prof. Dr:

Instituição: Julgamento:

Prof. Dr.:

Instituição: Julgamento:

Prof. Dr.:

Instituição: Julgamento:

Prof. Dr.:

Instituição: Julgamento:

Prof. Dr.:

Instituição: Julgamento: 


\section{DEDICATÓRIA}

"Ao Departamento de Nutrição e Produção Animal da Faculdade de Medicina Veterinária e Zootecnia da Universidade de São Paulo, em nome de todos os seus professores, funcionários e alunos, e todas as pessoas que participaram dessa jornada direta ou indiretamente, presente ou mesmo à distância...

A todos que acreditaram na minha capacidade me incentivando a concluir mais uma etapa em minha vida, pessoal e profissional.

Dedico aos colegas de trabalho, aos meus amigos queridos, ao meu amado namorado e meus familiares". 


\section{AGRADECIMENTOS}

À Universidade de São Paulo, a Faculdade de Medicina Veterinária e Zootecnia, e ao Departamento de Nutrição e Produção Animal pela oportunidade de realização deste curso;

Ao Conselho Nacional de Desenvolvimento Cientifico e Tecnológico (CNPq), à Fundação de Amparo a Pesquisa do Estado de São Paulo (FAPESP) e à Coordenação de Aperfeiçoamento de Pessoal de Nível Superior (CAPES) pela concessão da bolsa de estudo;

À Fundação de Amparo a Pesquisa do Estado de São Paulo (FAPESP) pela concessão da bolsa de estudo e pelo financiamento desta pesquisa;

A todos os estudantes, estagiários e funcionários do grupo de Pesquisa do Laboratório de Pesquisa em Bovinos de Leite da FMVZ USP ao longo desses 6 anos;

A todos os pós graduandos pertencentes, ou que já pertenceram ao Grupo de Pesquisa do Laboratório de Pesquisa em Bovinos de Leite da FMVZ-USP: Jefferson Rodrigues Gandra, José Esler Freitas Júnior, Rafael Villela Barletta, Elmesson Ferreira de Jesus, Pablo Gomes de Paiva, Caio Seiti Takiya, Vitor Pereira Bettero, Tiago Antônio Del Vale, Rodrigo Gardinal, Gustavo Delfino Calomeni, Taíssa Canaes, Filipe Zanferani, Thiago Henrique da Silva, Thiago Henrique Annibale Vendramini os quais estimo muito por toda colaboração, disponibilidade em ajudar de certa forma e por não medirem esforços em trabalhar em equipe!

A todos os professores e funcionários do Departamento de Nutrição e Produção Animal (VNP);

A empresa In Vitro pela realização das aspirações foliculares e manipulação dos embriões utilizados neste projeto;

Ao meu orientador Prof. Dr. Francisco Palma Rennó, pela oportunidade dada desde o início de mestrado e ao longo desses 6 anos, pelo privilégio em tê-lo como meu orientador, pela confiança depositada, pelos ensinamentos e palavras sábias, discussões, sugestões e críticas construtivas; enfim por fazer parte de minha formação e ser um exemplo de profissional e companheirismo. Deixo aqui minha enorme gratidão pelo senhor. Espero colaborar para o crescimento desta equipe;

Aos meus avós Herval e Jocelina, que sempre foram e serão os eternos incentivadores da minha luta em busca do conhecimento, por sempre acreditarem na minha capacidade $\mathrm{e}$ por terem me proporcionado minha formação nesta profissão; tornando realidade e possível tudo que almejei. Me apoiando, orgulhosos, presenciando e comemorando cada conquista!

Á minha mãe Adriana, por além de mãe ser minha Amiga, pelos conselhos e apoio, que nunca serão esquecidos...Por saber que posso contar com ela em tudo que precisar, e que mesmo distante, esteve muito perto, me dando força para lutar e seguir em frente; 
Aos meus irmãos Leandra e Leonardo por estarem muito além de apenas compartilharem os meus progenitores (rs), por serem desde minha infância pessoas de caráter, por sempre terem paciência, afeto e amor para comigo. Por sempre me apoiarem sem nunca contrariar... sinceras admirações são recíprocas. Em especial a minha irmã Leandra por ter me dado meu bem maior, meu sobrinho e afilhado querido!

Ao meu sobrinho Artur, que desde o seu primeiro dia de vida só nos trouxe alegria! Por ser essa criança mais linda e adorável. Por mesmo tão pequeno já ter passado por tanta coisa lutando pela sua vida! Por cada dia nos presentiar com uma surpresa evolução! Por isso comemoramos cada etapa e te amo mais que tudo!

Ao meu amado namorado Marcinho, por nunca medir esforços em me apoiar. Que me admira e me ama tanto... me estimulando a crescer cada vez mais. Por me passar segurança, por nunca me deixar desistir. Por tudo que faz por mim! Pela confiança, respeito, carinho, pelas palavras de conforto nos momentos bons e ruins, pelos momentos agradáveis juntos, pelo companheirismo e compreensão. Espero sempre estar ao seu lado e retribuir tudo que faz por mim. Eu te amo!

Agradeço também todos meus parentes próximos ou distantes, incluindo tios e primos, sogros e cunhados; e meus amigos que são muitos...desde os de infância em Amparo, fase de graduação em São João da Boa Vista, pós graduação em Pirassununga, etc... Os quais já perdi ou ainda mantenho contato, pelas lembranças boas, aprendizados, pelo companheirismo, afeto, por apenas serem o que são e fazerem parte da minha vida. Amizades verdadeiras que espero levar para o resto da vida, pois quem tem amigo tem tudo. Obrigada!!! 


\section{RESUMO}

VERDURICO, L. C. Efeito da suplementação prolongada de ácidos graxos insaturados na alimentação de novilhas Bos taurus sobre a qualidade oocitária e embrionária e perfil metabólico. [Effect of prolonged supplementation of unsaturated fatty acids in the diet of Bos taurus heifers on oocyte and embryo quality and metabolic profile]. 2015. $118 \mathrm{f}$. Tese (Doutorado em Ciências) - Faculdade de Medicina Veterinária e Zootecnia, Universidade de São Paulo, Pirassununga, 2015.

Objetivou-se avaliar os efeitos de diferentes fontes de ácidos graxos essenciais, ômega 3 e ômega 6, e o tempo de suplementação sobre a qualidade oocitária e embrionária em novilhas Bos taurus. Foram selecionadas 24 novilhas da raça Holandesa, divididas em três grupos experimentais os quais receberam as seguintes dietas: 1) Controle (CT) composto por dieta basal de aproximadamente 2,5\% de extrato etéreo; 2) Grão de Soja (GS) composto por uma dieta com aproximadamente 4,5\% de extrato etéreo, obtido com a inclusão de 11,5\% de grão de soja cru e integral na matéria seca (MS) da dieta, sendo fonte de ômega 6; 3) Semente de Linhaça (SL), composto por uma dieta com aproximadamente 4,5\% de extrato etéreo, baseada na inclusão de 6,0\% de semente de linhaça na MS da dieta, sendo fonte de ômega 3. Os animais foram arraçoados em grupos, de acordo com o consumo de matéria seca do dia anterior de forma a ser mantido porcentual de sobras diárias, entre 5 e $10 \%$ do consumo. Foi avaliada, por ultrassonografia, a atividade ovariana de todos os animais durante todo período de coleta. Foram realizadas aspirações foliculares precedidas de sincronização da emergência de onda de crescimento folicular em seis períodos, -30, 0, 30, 60, 90 e 120 dias, os oócitos recuperados foram classificados de acordo com sua morfologia. Foram considerados como viáveis e, consequentemente aproveitados para FIV somente os oócitos classificados como graus I, II e III, os demais foram descartados. Os animais foram pesados para mensuração de ganho médio de peso diário, e amostras de fluido folicular do folículo dominante e sangue foram coletadas concomitante às aspirações foliculares a fim de se avaliar os parâmetros metabólicos como glicose, colesterol total, colesterol HDL, colesterol VLDL, colesterol LDL, triglicerídeos e ureia, Houve efeito de tempo para o número de oócitos classificados em Grau I, número e taxa de embriões. Na avaliação dos contrastes ortogonais, foi observado efeito para o contraste 1 (CT vs GS+SL) quando se analisou a taxa de embriões viáveis, onde a dieta CT apresentou menor desempenho. Não foi observado efeito significativo dos tratamentos para ganho de peso diário e peso corporal das novilhas, onde o ganho de peso médio diário (GPD) entre os tratamentos foi de 1072 gramas para os animais do grupo controle, 972 gramas para o grupo tratado com grão de soja e 840 gramas para suplementação com semente de linhaça. Houve efeito de tempo para a pesagem dos animais alimentados com as dietas 
experimentais, em que foi observado um aumento significativo de peso dos animais. Para o ganho de peso diário (GPD) foi observado efeito para o contraste 1, em que os animais tratados com a dieta controle apresentaram maiores ganho de peso que os animais alimentados com dietas suplementadas com lipídeos. As duas fontes lipídicas avaliadas não diferiram entre si. Houve efeito de tempo para todas as variáveis do perfil metabólico sanguíneo analisadas ao longo de todo período experimental. Foi observado efeito de interação entre tempo e dieta para a variável glicose. $\mathrm{Na}$ análise dos contrastes foi observado efeito para o $\mathrm{C} 1$ (controle $v s$ grão de soja + semente de linhaça) onde os animais que consumiram dieta controle apresentaram em média 152,29 mg/dL de glicose em relação aos que consumiram dietas suplementadas com fontes de ácidos graxos (GS e SL) $(141,74+144,78)$ respectivamente. Houve efeito estatístico para interação entre tempo e dieta para os níveis de ureia. Na análise do fluído folicular foi observado interação entre tempo e dieta para as variáveis colesterol total e ureia. Foram observados efeitos significativos de dieta, interação tempo dieta e contraste 1 (CT vs GS + SL) quando se analisou a quantidade de triglicerídeos no fluído folicular. Portanto a suplementação prolongada com fontes de ácidos graxos insaturados na alimentação de novilhas não apresenta melhorias consideráveis na qualidade oocitária e embrionária dos animais, aumentando apenas a taxa de embriões viáveis, mas com prejuízos sobre o perfil metabólico e ganho médio de peso vivo.

Palavras-chave: Bos taurus, Embriões, Metabolismo, Produção, Reprodução. 


\begin{abstract}
VERDURICO, L. C. Effect of prolonged supplementation of unsaturated fatty acids in the diet of Bos taurus heifers on oocyte and embryo quality and metabolic profile. [Efeito da suplementação prolongada de ácidos graxos insaturados na alimentação de novilhas Bos taurus sobre a qualidade oocitária e embrionária e perfil metabólico]. 2015. 118 f Tese (Doutorado em Ciências) - Faculdade de Medicina Veterinária e Zootecnia, Universidade de São Paulo, Pirassununga, 2015.
\end{abstract}

This study aimed to evaluate the effects of different sources of essential fatty acids, omega 3 and omega 6, and the time of supplementation on oocyte and embryo quality in Holstein heifers. Will be selected 30 heifers Bos taurus, evenly divided into three groups which will receive the following diets: 1) Control (CT) basal diet composed of approximately 2,5\% ethereal stratum; 2) Soya Bean (GS) consists of a diet with approximately 4,5\% of ethereal layer based on inclusion of $12 \%$ of raw soybean and complete the concentrate, a source of omega 6; 3) Flax Seed (SL) composed of a diet with approximately 4,5\% ethereal stratum based on inclusion of $6,0 \%$ of flaxseed in the concentrate, a source of omega 3 . The animals are hand fed into groups according to the dry matter intake inside the day in order to be kept remains percentage of the diets on a daily basis between 5 and $10 \%$. Will be evaluated by ultrasound ovarian activity of all animals throughout the collection period. Be preceded by follicular aspiration performed synchronization emergency follicular wave into six periods, 30, 0, 30, 60, 90 and 120 days, the oocytes retrieved will be ranked according to their morphology, by measuring the amount of layers and compacting cumulus cells and homogeneity of the ooplasm. Are considered viable and therefore only the recovered oocytes for IVF classified as grade I, II and III, the other is discarded. Follicular fluid samples of the dominant follicle and the concomitant blood will be collected follicular aspiration in order to evaluate the metabolic and hormonal parameters such as glucose, total cholesterol, HDL cholesterol, VLDL cholesterol, LDL cholesterol, triglycerides, and urea. As expected outcome of the present study suggest that supplementation with fat has beneficial effects on follicle, the oocyte quality, the quality of in vitro embryo production and metabolic and hormonal profile of dairy heifers. There was a time effect on the number of oocytes classified as Class I, number and rate of embryos. In assessing orthogonal contrasts, effect was observed for the first contrast (CT vs GS + SL) when analyzing the rate of viable embryos, where the CT diet showed lower performance. There was no significant treatment effect on daily weight gain and body weight of heifers, where the average daily gain weight (GPD) between treatments was 1072 grams for the control group, 972 grams for the group treated with grain of soybeans 
and 840 grams for supplementation with flaxseed. There was a time effect for weighing animals fed experimental diets, it was observed a significant increase in initial weight to the final weight of the treated animals. In assessing orthogonal contrasts, effect was observed for the first contrast (CT vs GS + SL) for the GPD (daily weight gain) in the animals treated with the control diet showed higher values for average found weight gain, compared to diets with added lipid. However, when we analyzed the contrast 2 (GS vs SL) was not observed statistical effect of the tested variables. There was a time effects for all variables examined the metabolic profile of blood throughout the experimental period. There was a significant interaction effect between time and diet to the variable glucose. In the analysis of contrasts effect was observed for $\mathrm{C} 1$ (control versus soybean grain, flaxseed) where the animals fed the control diet had an average of $152.29 \mathrm{mg} / \mathrm{dL}$ glucose compared to those fed diets supplemented with acid sources fatty (GS and SL) $(141.74+144.78)$ respectively. There was no effect for interaction between time and diet for urea. In the analysis of follicular fluid was observed interaction between time and diet for the variables Total cholesterol and urea. Diet Significant effects were observed, time and diet interaction Contrast 1 (CT vs. GS + SL) where it is examined the amount of triglycerides in the follicular fluid. Therefore prolonged supplementation sources of unsaturated fatty acids in the diet of heifers not considerably improvements in oocyte and embryo quality animal, only increasing the rate of viable embryos, but with losses on the metabolic profile and average live weight gain.

Key-works: Bos taurus, Embryos, Metabolism, Production, Reproduction. 


\section{LISTA DE TABELAS}

Tabela 1 - Composição percentual dos concentrados experimentais.......................................50

Tabela 2 - Composição químico-bromatológica dos ingredientes.......................................... 51

Tabela 3 - Composição percentual das dietas experimentais................................................. 51

Tabela 4 - Composição químico-bromatológical das dietas experimentais........................... 52

Tabela 5 - Ganho de peso diário (GPD), peso corporal de novilhas alimentadas com dietas contendo fontes lipídicas suplementares

Tabela 6 - Parâmetros sanguíneos do perfil metabólico de novilhas alimentadas com dietas contendo fontes lipídicas suplementares .... 66

Tabela 7 - Perfil bioquímico do fluido folicular de novilhas alimentadas com dietas contendo

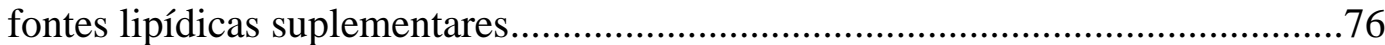

Tabela 8 - Oócitos, qualidade oocitária e produção de embriões de novilhas holandesas alimentadas com dietas suplementadas com diferentes sementes de oleaginosas por diferentes períodos de tempo 


\section{LISTA DE FIGURAS}

Figura 1 - Protocolo de sincronização hormonal utilizado nas novilhas dos grupos experimentais 56

Figura 2 - Ganho de peso diário (GPD) de novilhas alimentadas com grão de soja (GS) e semente de linhaça (SL) durante 120 dias de suplementação.

Figura 3 - Peso corporal de novilhas alimentadas com grão de soja (GS) e semente de linhaça (SL) durante 120 dias de suplementação

Figura 4- Concentrações de glicose no soro de novilhas alimentadas com grão de soja (GS) e semente de linhaça (SL)

Figura 5 - Concentrações de coleterol total no soro de novilhas alimentadas com grão de soja (GS) e semente de linhaça (SL)

Figura 6 - Concentrações de triglicerídeos no soro de novilhas alimentadas com grão de soja (GS) e semente de linhaça (SL)

Figura 7 - Concentrações de colesterol VLDL no soro de novilhas alimentadas com grão de soja (GS) e semente de linhaça (SL)

Figura 8 - Concentrações de colesterol HDL no soro de novilhas alimentadas com grão de soja (GS) e semente de linhaça (SL)

Figura 9- Concentrações de colesterol LDL no soro de novilhas alimentadas com grão de soja (GS) e semente de linhaça (SL)

Figura 10 - Concentrações de ureia no soro de novilhas alimentadas com grão de soja (GS) e semente de linhaça (SL).....

Figura 11 - Concentrações de proteína total no soro de novilhas alimentadas com grão de soja (GS) e semente de linhaça (SL)

Figura 12 - Concentrações de glicose no fluido folicular de novilhas alimentadas com grão de soja (GS) e semente de linhaça (SL)

Figura 13 - Concentrações de coleterol total no fluido folicular de novilhas alimentadas com grão de soja (GS) e semente de linhaça (SL)

Figura 14 - Concentrações de triglicerídeos no fluido folicular de novilhas alimentadas com grão de soja (GS) e semente de linhaça (SL) 80 
Figura 15 - Concentrações de ureia no fluido folicular de novilhas alimentadas com grão de soja (GS) e semente de linhaça (SL)

Figura 16 - Número de oócitos totais obtidos a partir das OPUs realizadas com os animais dos grupos experimentais: CT: Controle; GS: Grão de Soja; SL: Semente de Linhaça

Figura 17 - Número de oócitos viávies obtidos a partir das OPUs realizadas com os animais dos grupos experimentais: CT: Controle; GS: Grão de Soja; SL: Semente de Linhaça 86

Figura 18 - Número de oócitos de Grau I (G1) obtidos a partir das OPUs realizadas com os animais dos grupos experimentais CT: Controle; GS: Grão de Soja; SL: Semente de Linhaça. .86

Figura 19 - Número de oócitos de Grau II (G2) obtidos a partir das OPUs realizadas com os animais dos grupos experimentais CT: Controle; GS: Grão de Soja; SL: Semente de Linhaça.

Figura 20 - Número de oócitos de Grau III (G3) obtidos a partir das OPUs realizadas com os animais dos grupos experimentais CT: Controle; GS: Grão de Soja; SL: Semente de Linhaça.....

Figura 21 - Oócitos classificados em Grau I (G1), Grau II(G2) e Grau III (G3) obtidos a partir das OPUs realizadas com os animais dos grupos experimentais CT: Controle; GS: Grão de Soja; SL: Semente de Linhaça. .88

Figura 22 - Número de oócitos clivados obtidos a partir das OPUs realizadas com os animais dos grupos experimentais: CT: Controle; GS: Grão de Soja; SL: Semente de Linhaça 88

Figura 23 - Número de oócitos cultivados obtidos a partir das OPUs realizadas com os animais dos grupos experimentais: CT: Controle; GS: Grão de Soja; SL: Semente de Linhaça..... .89

Figura 24 - Número de embriões totais obtidos a partir dos oócitos cultivados, provenientes das OPUs realizadas com os animais dos grupos experimentais: CT: Controle; GS: Grão de Soja; SL: Semente de Linhaça.

Figura 25 - Porcentagem de embriões totais obtidos a partir dos oócitos cultivados, provenientes das OPUs realizadas com os animais dos grupos experimentais: CT: Controle; GS: Grão de Soja; SL: Semente de Linhaça........ 90 
Figura 26- Porcentagem de oócitos viáveis obtidos a partir dos oócitos totais, provenientes das OPUs realizadas com os animais dos grupos experimentais: CT: Controle; GS: Grão de Soja; SL: Semente de Linhaça.........90

Figura 27- Porcentagem de clivagem obtidos a partir dos oócitos totais, provenientes das OPUs realizadas com os animais dos grupos experimentais: CT: Controle; GS: Grão de Soja; SL: Semente de Linhaça 91 


\section{ABREVIAÇÕES}

MS Matéria Seca

MO Matéria orgânica

PB Proteína bruta

EE Extrato etéreo

AGNE Ácidos graxos não esterificados

CNF Carboidrato não fibroso

CMS Consumo de matéria seca

IMS Ingestão de matéria seca

CDMS Coeficiente de digestibilidade da matéria seca

BE Balanço de energia

ECC Escore de condição corporal

SL Dieta experimental semente de linhaça

GS Dieta experimental grão de soja cru e integral

AGP Ácidos graxos poliinsaturados

LH Hormônio luteinizante

FSH Hormônio folículo estimulante

PGF Prostaglandina

GnRH Hormônio liberador de gonadotrofinas

FD Folículo dominante

IGF 1 Fator de crescimento semelhante à insulina tipo 1

GH Hormônio de crescimento

US Ultrassonografia

FF Fluido folicular

CCO Complexo cúmulos oócito

OPU Aspiração folicular

FIV Fertilização in vitro

MIV Maturação in vitro

CIV Cultivo in vitro

PIV Produção in vitro 
1 INTRODUÇÃO ...................................................................................................................... 18

$3 \quad$ OBJETIVOS......................................................................................................................22

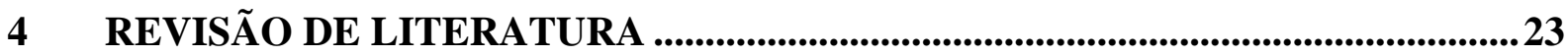

4.1 MANEJO E CRIAÇÃO DE NOVILHAS LEITEIRAS .........................................23

4.2 CICLO ESTRAL EM NOVILHAS .........................................................................26

4.3 RELAÇÃO NUTRIÇÃO E REPRODUÇÃO ..........................................................32

4.4 SUPLEMENTAÇÃO DE ÁCIDOS GRAXOS POLIINSATURADOS ..............35

4.4.1 FONTES DE ÁCIDOS GRAXOS $\Omega 3$ E $\Omega 6$ NA ALIMENTAÇÃO DE NOVILHAS...................................................................................................................................39

4.5 INFLUÊNCIA DOS ÁCIDOS GRAXOS DA FAMÍLIA $\omega 3$ E $\omega 6$ NO DESEMPENHO DE NOVILHAS .....................................................................41

4.5.1 Perfil metabólico ............................................................................................ 41

4.6 INFLUÊNCIA DOS ÁCIDOS GRAXOS $\omega 3$ E $\omega 6$ NA QUALIDADE OOCITÁRIA E EMBRIONÁRIA DE NOVILHAS..................................................44

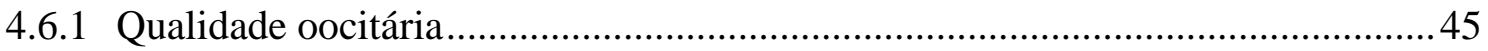

4.6.2 Qualidade embrionária …………………………………………………….... 47

5 MATERIAL E MÉTODOS........................................................................................49

5.1 ANIMAIS E INSTALAÇÕES ........................................................................................49

5.2 DIETAS EXPERIMENTAIS E ANÁLISE DE ALIMENTOS ...................................49

5.3 AVALIAÇÃO DE PESO CORPORAL E GANHO DE PESO DIÁRIO .................52

5.4 COLETA DE SANGUE E FLUÍDO FOLICULAR PARA ANÁLISE METABÓLICA ...................................................................................................................52

5.5 ULTRASSONOGRAFIA OVARIANA E ASPECTOS REPRODUTIVOS ............55

5.6 PROTOCOLO DE SINCRONIZAÇÃO PARA OPU ...................................................55

5.7ASPIRAÇÃO FOLICULAR (OPU),..............................................................................56

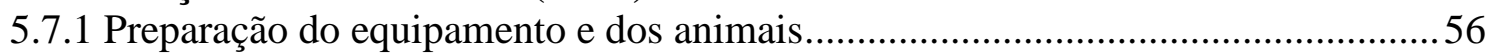

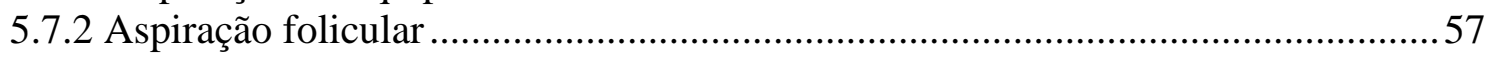

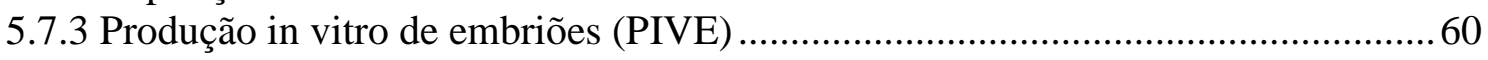


6 ANÁLISES ESTATÍSTICAS ................................................................................62

7 RESULTADOS E DISCUSSÃO .....................................................................63

7.1 PESO CORPORAL E GANHO MÉDIO DE PESO ..................................................63

7.2 PARÂMETROS SANGUÍNEOS ...............................................................65

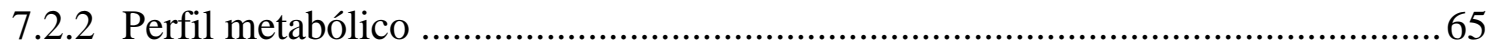

7.3 PARÂMETROS LÍQUIDO FOLICULAR ..................................................76

7.3.1 Perfil metabólico .........................................................................................

7.4 QUALIDADE OOCITÁRIA E EMBRIONÁRIA.................................................81

8 CONCLUSÃO

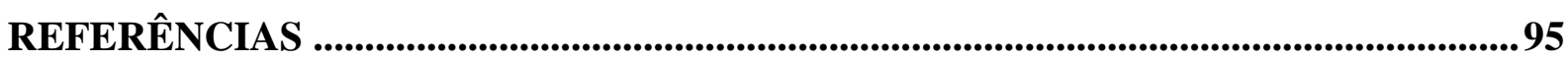




\section{INTRODUÇÃO}

A criação de novilhas de reposição direcionadas para a produção leiteira é atividade essencial dentro de sistemas de produção de leite, sendo, no entanto, categoria animal que nem sempre recebe adequada atenção dentro dos rebanhos leiteiros. Muitas vezes esta categoria é relegada à plano inferior em relação a outros animais do rebanho, como as vacas em lactação e bezerras. No entanto, o custo de criação de novilhas é considerado a segunda maior fonte de custos de produção dentro de rebanhos leiteiros, estando relacionado a uma variação de 9 a $20 \%$ dos custos totais de produção.

Uma forma eficiente de redução desses custos é a redução da idade ao primeiro parto de novilhas leiteiras, estando associadas à diminuição dos gastos com alimentação e a um retorno precoce do investimento, além da redução no inventário de novilhas. Idades ao primeiro parto de 23 a 30 meses podem resultar em maior produção de leite por vaca por dia útil de vida, aumentando a lucratividade da vaca leiteira ao longo de sua vida produtiva.

Os fatores nutricionais podem influenciar diretamente o desempenho reprodutivo. Porém, a relação entre a nutrição e a reprodução nesta fase é complexa. Mudanças no plano nutricional e na condição corporal podem alterar a liberação e síntese de hormônios, a qualidade dos oócitos e o crescimento folicular, pois podem agir no eixo hipotálamo-hipófiseovários.

Em ruminantes, tais mudanças nutricionais eventualmente não influenciam de forma significativa a liberação e concentração sanguínea de gonadotrofinas, entretanto, podem promover desequilíbrio nas concentrações circulantes de vários metabólicos e hormônios ligados ao metabolismo animal como a insulina, IGF-1 e leptina. O desequilíbrio metabólico ocasiona alterações sistêmicas que podem interferir no sucesso das biotecnologias reprodutivas, tais como a fertilização in vitro (FIV) que, por sua vez, depende da qualidade inicial dos oócitos.

A resposta neuroendócrina reflete-se nas concentrações hormonais e de nutrientes no plasma sanguíneo e afeta muitos aspectos do desempenho reprodutivo em ruminantes, tais como idade à puberdade em ambos os sexos, taxa de fertilidade e de ovulação, sobrevivência embrionária, parto, intervalo de partos, desenvolvimento testicular e produção de espermatozoides.

Dentre os fatores nutricionais responsáveis pelas variáveis reprodutivas, podem-se destacar a concentração de ácidos graxos na dieta, condição corporal e densidade energética 
da dieta, os quais têm efeitos sobre os níveis plasmáticos de substâncias determinantes do perfil metabólico dos animais.

As gorduras e óleos são nutrientes essenciais na alimentação animal, pois proporcionam uma fonte altamente concentrada de energia, além de serem componentes críticos da estrutura física e funcional das células, apesar da impossibilidade dos animais (diferentemente dos vegetais) em sintetizar estes ácidos graxos a partir de precursores estruturalmente mais simples, pela carência de enzimas específicas para isso.

A dieta de ruminantes alimentados basicamente com forrageiras tem baixo teor de lipídios (entre 1 e $4 \%$ da MS), representados, principalmente, pelos galactolipídeos e triglicerídeos, sendo que níveis mais altos podem ser obtidos pela adição de lipídeos ou de sementes oleaginosas na dieta, tendo-se o cuidado de não ultrapassar 6-7\% de extrato etéreo na MS da dieta, o que inibiria a fermentação ruminal, através de uma inibição mecânica da ação da microflora celulolítica e de um efeito tóxico dos ácidos graxos insaturados sobre as membranas celulares bacterianas. O conteúdo de óleo das forragens e de vários grãos, embora seja usualmente baixo, possui altas proporções de ácidos graxos polinsaturados, em particular os ácidos oleico C18:1 e linoleico C18:2. As concentrações energéticas relatadas pelo NRC (2001) são cerca de duas vezes maiores para as fontes lipídicas do que para os grãos de cereais, porém é importante assegurar que a utilização de outros componentes da dieta não seja muito afetada quando os suplementos lipídicos são incluídos na mesma.

Dentre os fatores que exercem influência na reprodução, a nutrição tem um papel reconhecidamente importante por afetar diretamente aspectos da fisiologia reprodutiva da fêmea bovina. Há muita controvérsia sobre os efeitos do "flushing" nutricional ou incremento na ingestão de matéria seca (IMS) sobre a fertilidade e produção embrionária em ruminantes. Por outro lado, como aspecto positivo, diversos trabalhos têm demonstrado resultados favoráveis com o uso de suplementos à base de lipídios sobre a função reprodutiva de fêmeas de corte e leite.

As principais famílias de ácidos graxos polinsaturados (AGPs) que afetam a fertilidade são ômega 3 ( $\omega$-3) e ômega ( $\omega-6)$. O ácido linoleico dietético é um dos representantes da família $\omega-6$, o qual é convertido em ácido araquidônico, precursor das prostaglandinas dienoicas, como a PGF2 $\alpha$. Por outro lado, o ácido linolênico ( $\omega$-3) é convertido a ácido eicosapentaenoico precursor das prostaglandinas trienoicas, como PGF3 $\alpha$. Deste modo, a produção das prostaglandinas pode ser manipulada de acordo com a proporção de ácidos graxos presentes na dieta. 
A causa da associação observada entre o tempo e suplementação com lipídeos e maiores concentrações circulantes de hormônios esteroides relatada por diversos autores não está bem definida. Especula-se que pode ser por meio da ação dos AGPs, aumentando a pulsatilidade de hormônio luteinizante (LH), ou redução do metabolismo hepático, com um consequente aumento no tamanho do folículo pré-ovulatório. Outra possibilidade seria aumentando as concentrações circulantes de colesterol, precursor da síntese de esteroides. A teoria da diminuição do metabolismo dos esteróides é atualmente uma das mais aceitas para explicar as maiores concentrações de esteroides na suplementação lipídica.

A suplementação lipídica tem efeitos benéficos no folículo, sobre a qualidade oocitária e sobre a produção de embriões in vitro em vacas leiteiras. O mecanismo pelo qual os lipídios dietéticos proporcionam melhora na produção e qualidade oocitária e embrionária parece estar relacionados com a atenuação do balanço energético negativo e com a depressão na síntese de prostaglandinas uterinas. No entanto o ácido graxo específico ou o grupo de ácidos graxos que causam essa melhora, e o tempo ideal de suplementação lipídica em novilhas ainda não são totalmente conhecidos. 


\section{HIPÓTESE}

A suplementação com ácidos graxos ômega 3 e ômega 6 influencia positivamente o perfil metabólico e a qualidade oocitária, otimizando o desempenho reprodutivo de novilhas da raça Holandesa, através da melhora na produção de embriões, sendo a resposta dependente do tempo de suplementação e tipo de ácido graxo utilizado. 


\section{OBJETIVOS}

Objetivou-se avaliar os efeitos de diferentes fontes de ácidos graxos essenciais (ômega 3 e ômega 6), e o tempo de suplementação sobre:

- Ganho médio de peso;

- Perfil metabólico sanguíneo;

- Perfil metabólico do fluído folicular do folículo dominante;

- Qualidade oocitária e embrionária.

Foram avaliados:

1) Ganho de peso diário;

2) Perfil bioquímico sanguíneo: glicose, colesterol total, colesterol HDL, LDL e VLDL, triglicerídeos, ureia e proteínas totais;

3) Perfil bioquímico do fluído folicular: glicose, colesterol total, triglicerídeos e ureia;

4) Qualidade oócitaria;

5) Qualidade e produção in vitro de embriões. 


\section{REVISÃO DE LITERATURA}

\subsection{MANEJO E CRIAÇÃO DE NOVILHAS LEITEIRAS}

A criação de novilhas de reposição direcionadas para a produção leiteira é atividade essencial dentro de sistemas de produção de leite, sendo, no entanto, categoria animal que não tem recebido a adequada atenção dentro de rebanhos leiteiros. Muitas vezes esta categoria é relegada a um plano inferior em relação a outros animais do rebanho, como as vacas em lactação e bezerros.

A criação de animais de reposição é uma das atividades de maior importância na condução dos rebanhos leiteiros e tem como objetivo principal a substituição das vacas produtoras de leite, sendo os excedentes destinados à venda (NEIVA, 2000). Os rebanhos de cria, novilhas e vacas primíparas representam, aproximadamente, $40 \%$ do total de ventres produtivos, e especial atenção deve ser dedicada a estas categorias. Desta maneira, o desenvolvimento de fêmeas de reposição e uma fase crítica em sistemas de produção de bovinos, em que a idade média ao primeiro parto, no Brasil, está acima de 40 meses de idade, em consequência de uma alimentação e manejo inadequados (SEMMELMANN et al., 2001).

O custo de criação de novilhas leiteiras é considerado a segunda maior fonte de custos de produção dentro de rebanhos leiteiros, estando relacionado a uma variação de 9 a $20 \%$ dos custos totais de produção (BAILEY; MURPHY, 1999), sendo que aproximadamente $60 \%$ é destinado à alimentação do rebanho.

A eficiência econômica na atividade leiteira está se tornando a maior preocupação de empresários rurais, e gastos com a recria de novilhas podem ser reduzidos com sucesso. De acordo com dados italianos (PIRLO et al., 1997), a criação desta categoria animal representa $20 \%$ dos gastos totais com a produção de leite. A principal estratégia para baixar estes custos é reduzir o período de criação (idade ao primeiro parto entre 22,5 e 23,5 meses), sem deixar de levar em consideração o potencial genético desses animais, visando amortizar o investimento em pelo menos duas ou até três lactações.

Segundo Sejrsen e Purup (1997), a redução da idade ao primeiro parto seria a forma mais eficiente de redução dos custos de criação de novilhas leiteiras, estando estas reduções de custo associadas à diminuição dos gastos com alimentação e a um retorno do investimento de forma precoce (LIN et al., 1986; GARDNER et al., 1988), além da redução no inventário 
de novilhas (GOMES et al., 2001). Idades ao primeiro parto de 23 a 30 meses resultariam em maior produção de leite/vaca/dia útil de vida, resultando em aumentos na lucratividade da vaca leiteira ao longo de sua vida produtiva (GILL; ALLAIRE, 1976; GARDNER et al., 1977).

A alimentação de bovinos de leite é determinada pelas necessidades corporais de mantença, crescimento, gestação ou reprodução e produção de leite (ENSMINGER; OLENTINE, 1978). Para novilhas em recria, as exigências diárias em energia, proteína e minerais/vitaminas são baseadas nas determinações de mantença e ganho de peso. Práticas alimentares de animais leiteiros são dependentes do entendimento das exigências nutricionais para funções produtivas e otimização da lucratividade. Isso requer informações de exigências específicas para cada função produtiva, consumo de alimentos e a contribuição de cada alimento em satisfazer essas necessidades nutricionais. Por definição, exigências nutricionais podem constituir concentração mínima de nutrientes necessários para se evitar sintomas clássicos de deficiência (NOLLER; MOE, 1995). Segundo McBride et al. (1998), a exigência do corpo animal representaria a soma dos nutrientes utilizados pelos tecidos.

Um importante fator que influencia a variação para o início da puberdade, dentro das raças, é o nível de alimentação (ROBINSON, 1990; SCHILLO et al., 1992). A magnitude deste efeito pode ser observada no trabalho de Foldager et al. ${ }^{1}$, (1988), apud Sejrsen e Purup (1997). A média de idade ao primeiro cio diminuiu de 16,6 para 8,4 meses à medida que a taxa de ganho de peso aumentou de 450 para $850 \mathrm{~g} /$ dia. Por este raciocínio, as novilhas deveriam ser alimentadas para atingirem altas taxas de ganhos até a puberdade, a fim de se obter uma redução significativa na idade ao primeiro parto.

O início da puberdade é definido como o primeiro comportamento estral acompanhado pelo desenvolvimento de um corpo lúteo e mantido pelo período característico da espécie (KINDER et al., 1987). Em outras palavras, o início da puberdade relaciona-se ao primeiro estro da novilha, seguido por uma fase lútea fisiológica.

A puberdade é um evento que depende da maturação do hipotálamo, a qual depende, principalmente, do aumento da secreção pulsátil do hormônio luteinizante (LH) (KINDER et al., 1995), e a nutrição influencia esse processo, visto que a restrição alimentar energética atrasa a puberdade por inibição do desenvolvimento do sistema reprodutivo endócrino (DAY et al., 1986).

\footnotetext{
1 FOLDAGER, J. K. SEJRSEN, AND J. T. SORENSEN. The effect of plane of nutrition on growth and feed utilization in RDM and SDM heifers - revision of energy requirements for growth. (In Danish with English summary and subtitles.) Report 648, Natl. Inst. Anim. Sci., Foulum, Denmark, 1988.
} 
O termo puberdade é usado para definir o início da vida reprodutiva e, para a fêmea, o início da atividade ovariana. Na vaca, tanto a raça como a nutrição tem influência no início da puberdade. A ingestão de um alto nível energético permite o início da vida reprodutiva o mais cedo possível, sendo tanto o tamanho quanto a idade do animal importantes em determinar a maturidade sexual. Segundo Hafez (1993), o peso corpóreo ótimo e a idade para novilhas reprodutoras da raça Holandesa iniciarem uma gestação seria de $340 \mathrm{~kg}$ aos 15 meses de idade.

A idade à puberdade da fêmea bovina pode ser afetada pela composição genética, peso à desmama e nutrição pós-desmama (WARNICK et al., 1956), heterose (WILTBANK et al., 1969) e presença de touro (ROBERSON et al., 1991). A puberdade em novilhas é mais relacionada com o peso do que com a idade. As novilhas atingem a puberdade com 30 a $40 \%$ do peso adulto médio.

Além disso, no começo da puberdade, uma onda de GnRH promove a liberação de uma onda de LH (hormônio luteinizante) da hipófise anterior, a qual estimula a ovulação de um folículo pré-ovulatório. Assim, o eixo reprodutivo hipotalamico-hipofisiario-gonadal atua como um sistema regulador da reprodução, sendo o hipotálamo o componente final para regular o inicio da puberdade em novilhas (NAKADA et al., 2002).

O controle da reprodução por meio do sistema nervoso central em novilhas é exercido principalmente pelas gonadotrofinas FSH e LH (MORAN et al., 1989). As concentrações dessas gonadotrofinas estão em níveis elevados em fêmeas pré-puberes quando comparadas as fêmeas que já alcançaram a puberdade, indicando que a hipófise é capaz de sintetizar e armazenar FSH e LH antes da puberdade (KINDER et al., 1987).

As novilhas de raças leiteiras, em geral, atingem a puberdade em idade menor do que as novilhas de raças de corte. No entanto, cuidados devem ser tomados para que o ganho de peso até a puberdade não prejudique o desempenho produtivo destas novilhas. $\mathrm{O}$ ganho em peso não deve ser superior a 800g/dia (SERJSEN, 2007).

Em novilhas de raças grandes, o início da puberdade normalmente se dá aos 9-11 meses de idade e peso vivo médio variando entre $250-280 \mathrm{~kg}$. Entretanto, estes parâmetros podem variar amplamente, tanto dentro de raças quanto entre raças. Em experimentos com novilhas das raças Holandesa e Dinamarquesa vermelha, foi observado início de puberdade tão cedo quanto 5 a 6 meses e tão tardio quanto 18 a 20 meses (FOLDAGER et al. ${ }^{2}, 1988$,

\footnotetext{
Foldager, ${ }^{2}$ J., K. Sejrsen, and J. T. Sorensen. 1988. The effect of plane of nutrition on growth and feed utilization in RDM and SDM heifers - revision of energy requirements for growth. (In Danish with English summary and subtitles.) Report 648, Natl. Inst. Anim. Sci., Foulum, Denmark.
} 
apud SEJRSEN; PURUP, 1997). A variação no peso vivo também foi muito ampla (150 a 400 $\mathrm{kg}$ ); entretanto, menos que 5\% das novilhas atingiram a puberdade antes de $200 \mathrm{~kg}$ de peso vivo e menos que $10 \%$ apresentaram cio após $300 \mathrm{~kg}$.

Portanto fica claro que a nutrição de novilhas leiteiras influencia a chegada da puberdade além da idade ao primeiro parto, pois alterações nutricionais podem influenciar diretamente o desempenho reprodutivo (BUTLER, 1998; BEAM; BUTLER, 1998; WEBB et al., 1999; LUCY, 2000, 2003; ARMSTRONG et al., 2003; WEBB et al., 2004; SANTOS et al., 2008).

Novilhas taurinas leiteiras (principalmente da raça Holandesa), quando manejadas adequadamente, podem atingir a puberdade com menos de um ano de idade. Nesta fase, elas já devem estar pesando acima de $300 \mathrm{~kg}$ de peso vivo e estarem aptas a entrarem em um programa reprodutivo. Muitas vezes, entretanto, recomenda-se aguardar até que elas se desenvolvam um pouco mais para inseminá-las, contanto que a idade ao primeiro parto não ultrapasse os 24 meses (RUAS et al., 2004; CARVALHO, 2005). Programas de sincronização de estro têm sido usados com muita eficácia em novilhas leiteiras, principalmente por facilitarem o manejo dos animais sem, entretanto, comprometerem significativamente sua fertilidade. Além disso, através da sincronização, as novilhas são inseminadas, e consequentemente emprenham mais cedo, gerando lucro para o produtor.

Segundo Martin et al. (1992), o desempenho reprodutivo das novilhas depende da idade em que essas fêmeas parem pela primeira vez. Novilhas que parem mais cedo podem ter maior vida produtiva que as fêmeas mais tardias; assim, novilhas que parem pela primeira vez aos dois anos de idade deverão produzir mais bezerros do que as que parem aos três anos de idade. Entre as principais vantagens em emprenhar as novilhas mais jovens estão: menor tempo para obter retorno do investimento, aumento da vida reprodutiva da vaca e aumento do número de bezerros (SHORT et al., 1994).

\subsection{CICLO ESTRAL EM NOVILHAS}

Ciclo estral define-se como sendo o rítmo funcional dos órgãos femininos que se estabelece a partir da puberdade. Compreende as modificações cíclicas na fisiologia e na morfologia dos órgãos genitais e também no perfil dos hormônios relacionados (ANTONIOLLI, 2002). 
As fêmeas da espécie bovina ao atingirem a puberdade exibem comportamento estral em média a cada 21 dias, variando de 17 a 24 dias tanto em raças europeias (ROBINSON; SHELTON, 1991; WRIGHT; MALMO, 1992; BO; ADAMS; MAPLETOFT; 2000) quanto zebuínas (GALINA; ARTUR, 1990; PINHEIRO et al., 1998; FIGUEIREDO et al., 1997; GAMBINI et al., 1999) até que a prenhez se estabeleça. A fêmea bovina é poliéstrica anual (MIES FILHO, 1977).

De acordo com Drost (1995), o ciclo estral é dividido em quatro fases, baseado em eventos fisiológicos e endocrinológicos: estro (dia 0), metaestro (dia 1-4), diestro (dia 5-18) e proestro (dia 19 até o estro). Existe ainda uma divisão mais simplificada: fase folicular, que compreende desde o crescimento folicular até ovulação e fase luteínica, que vai do surgimento do corpo lúteo (CL) até sua regressão com produção de progesterona (DROST, 1995; HAFEZ; HAFEZ, 2004). Pode-se dividir também em domínio estrogênico, que seria a fase folicular, e domínio progestágeno ou fase luteínica.

O ciclo estral é regulado por mecanismos endócrinos e neuroendócrinos, principalmente por hormônios hipotalâmicos, as gonadotrofinas e os estereóides secretados pelos ovários (HAFEZ; HAFEZ, 2004), e é caracterizado pelo crescimento e regressão de folículos e do CL.

Em bovinos, o crescimento do folículo primordial, uma vez iniciado, persiste até que ocorra a ovulação ou atresia. Os mecanismos que desencadeiam o início e número de folículos primordiais recrutados para o crescimento ainda não são totalmente conhecidos. Há evidências que o período necessário para o folículo primordial alcançar o estágio préovulatório é de aproximadamente 90 dias (CAMPBELL; SCARAMUZZI; WEBB, 1995). Durante o desenvolvimento inicial, os folículos primordiais crescem sob a influência de fatores de crescimento, secretados pelas células que circundam o oócito, e a partir da formação do antro folicular passam a ser dependentes de gonadotrofinas (WEBB et al., 2004). Durante tal período de desenvolvimento, além dos fatores de crescimento locais e de gonadotrofinas, os folículos podem ser influenciados por fatores externos, como a nutrição (LEROY et al., 2008).

Durante este crescimento, a morfologia folicular é alterada, uma vez que o oócito cresce e as células circundantes se multiplicam e se diferenciam (BRISTOL-GOULD; WOODRUFF, 2006). Para controlar estas mudanças, diferentes fatores de crescimento e hormônios agem de forma sincrônica, a fim de regular todos os eventos que ocorrem no desenvolvimento folicular. Apesar da importância que esta regulação exerce sobre a fertilidade de fêmeas, as substâncias envolvidas em muitos dos aspectos relacionados à 
foliculogênese, principalmente na fase inicial, permanecem ainda pouco elucidadas (HUTT et al., 2006). No entanto, diversos trabalhos vêm sendo realizados na tentativa de esclarecer os mecanismos e as substâncias envolvidas em cada fase da foliculogênese (FIGUEIREDO et al., 2008). Dentre estas substâncias, pode-se destacar a atuação dos hormônios hipofisários, FSH, LH, GH e TSH, que sabidamente desempenham um papel direto ou indireto na manutenção da viabilidade, bem como no estímulo ao crescimento e à maturação folicular (SIROTKIN; MAKAREVICH, 2002; BALDRIDGE et al., 2004; MATOS et al., 2007; SARAIVA et al., 2008).

De acordo com Antoniolli (2002), o GnRH (hormônio liberador de gonadotrofina) é secretado pelo hipotálamo através do sistema portahipotalâmico-hipofisário, atingindo a hipófise e estimulando a liberação das gonadotrofinas: o FSH (hormônio folículo estimulante), o qual estimula a proliferação e diferenciação das células da granulosa e induz a formação do antro e o LH (hormônio luteinizante) tem como principal função, em folículos não ovulatórios, estimular a atividade da enzima esteroidogênica, a aromatase p450, nas células da teca, além de promover a ovulação e estimular a luteinização das células da granulosa e células da teca em folículos pré-ovulatórios (RICHARDS et al., 2002). O LH é secretado de forma pulsátil; o FSH é secretado de maneira constitutiva, isto é, grande parte do hormônio é liberada na velocidade em que é produzida, embora uma pequena parcela possa ser armazenada para ser liberada em resposta ao GnRH (FARNWORTH, 1995). Estes hormônios agem de maneira coordenada na regulação do crescimento e diferenciação gonadal, na esteroidogênese e gametogênese, regulando, por conseguinte, o ciclo estral em fêmeas mamíferas (KUMAR; MATZUK, 2000).

$\mathrm{O}$ aumento inicial das gonadotrofinas parece ser subsequentemente suprimido pelo feed back negativo até que a novilha esteja apta à reprodução. Embora nos animais adultos, o estradiol pareça ser o agente primário no feed back negativo sobre a secreção de LH (atuando indiretamente através do sistema neuronal), a supressão inicial do aumento no período inicial pós-natal da secreção do LH pode não envolver o estradiol (MOSELEY et al., 1984; DAY; ANDERSON, 1998), mas sim mecanismos opiodorgênicos e dependentes de estradiol (WOLFE et al., 1991). De 40-80 dias antes da primeira ovulação, a sensibilidade da secreção do LH à supressão do feed back negativo diminui, permitindo que a secreção do LH aumente (aumento na frequência dos pulsos de LH) e intensificando o desenvolvimento do folículo antral e a secreção de estrogênio. Concentrações de estrogênio aumentadas consequentemente causam uma onda pré-ovulatória de LH. 
O ciclo estral em bovinos tem como padrão a formação de ondas de crescimento folicular (EVANS; ADAMS; RAWLINGS, 1994). Cada onda é caracterizada pelo rápido crescimento de um grupo de pequenos folículos, conhecido como emergência folicular (ADAMS; PIERSON, 1995). Em vacas Bos taurus, predominam ciclos estrais com duas ondas de crescimento folicular, podendo ocorrer até quatro em novilhas (SARTORI et al., 2004; WOLFENSON et al., 2004). Já em Bos indicus, predominam 3 ondas de crescimento folicular (ZEITOUN; RODRIGUEZ; RANDEL, 1996; VIANA et al., 2000; MOLLO et al., 2007). Porém, em recente revisão, Sartori et al. (2010) relataram que vacas Bos taurus e Bos indicus apresentam número de ondas foliculares e amplitude do ciclo estral semelhantes. Independente do número de ondas foliculares, as fêmeas Bos indicus apresentam maior número de folículos por onda de crescimento folicular do que as Bos taurus (CARVALHO et al., 2008; GIMENES et al., 2009; BASTOS et al., 2010). As fêmeas Bos taurus apresentam menores concentrações plasmáticas de IGF-1 e insulina (ALVAREZ et al., 2000; BÓ; BARUSELLI; MARTINEZ, 2003; BASTOS et al., 2010) e maiores de FSH quando comparadas às vacas Bos indicus (ALVAREZ et al., 2000). Tal diferença pode justificar a maior sensibilidade das doadoras Bos indicus ao tratamento superovulatório (BARROS; NOGUEIRA, 2001).

Em media, 95\% dos ciclos estrais mostram de duas a três ondas de crescimento folicular. Apesar de todos os fatores que afetam o desenvolvimento folicular não estarem totalmente elucidados, pode-se afirmar que a fertilidade não é afetada pelo número de ondas.

Durante o ciclo estral ocorrem importantes alterações no córtex ovariano que incluem crescimento e atresia de vários folículos antrais até o aparecimento do folículo ovulatório, bem como a formação e lise do corpo lúteo (CASTILHO, 1999). O crescimento folicular na espécie bovina exibe padrão contínuo de crescimento e a atresia dos folículos ovarianos (MATTON et al., 1981; WOOLUMS; PETTER, 1994) que se inicia na vida fetal, passa pela puberdade (EVANS et al., 1997) e continua na vida reprodutiva até a senilidade (HAFEZ, 1993). Muitos estudos com ultrassonografias seriadas foram realizados e demonstraram que durante o ciclo estral de novilhas ocorrem duas (PIERSON; SIROIS; SAVIO, 1988; GINTHER; KNOPF, 1989; FIGUEIREDO et al., 1997) ou três (SAVIO et al., 1988; GAMBINI et al., 1998; BARROS et al., 1993; FIGUEIREDO et al., 1997; CASTILHO et al., 2000) ondas de crescimento folicular.

A regulação da proliferação e da diferenciação celular, bem como da atresia, relacionadas com a foliculogênese ovariana, é resultado de uma complexa interação entre fatores locais e endócrinos (SILVA et al., 2006). 
A foliculogênese, evento iniciado na vida pré-natal na maioria das espécies, pode ser definida como o processo de formação, crescimento e maturação folicular, iniciando-se com a formação do folículo primordial e culminando com o estádio de folículo pré-ovulatório (VAN DEN HURK; ZHAO, 2005). O folículo ovariano é a unidade estrutural básica e funcional dos ovários de mamíferos, que promove o microambiente necessário para o crescimento e a maturação do oócito (GOSDEN et al., 1993). É composto por um oócito circundado por células da granulosa e/ou células da teca. Dessa forma, os folículos podem ser classificados, de acordo com o grau de evolução, em folículos pré-antrais (primordiais, primários e secundários), correspondendo à fase lenta, e antrais terciários e pré-ovulatórios, correspondendo à fase rápida, respectivamente (SILVA, 2005). A primeira fase (fase lenta) possui um período superior a 30 dias desde a aquisição do antro (aproximadamente $300 \mu \mathrm{m}$ ) até o estágio de folículo pequeno (3-5 mm de diâmetro) (LUSSIER et al., 1987). A segunda fase normalmente possui aproximadamente 5-7 dias, e inclui a emergência da onda dos folículos, desenvolvimento folicular, seleção do folículo dominante e um período variável de dominância seguido de ovulação ou regressão.

Nos bovinos em média 7 à 11 folículos estão presentes na emergência da onda folicular. A emergência de uma nova onda é precedida pelo aumento do FSH (ADAMS et al., 1992). A supressão do FSH previne crescimento posterior dos folículos de $3-5 \mathrm{~mm}$ (TURZILLO; FORTUNE, 1990), enquanto que tratamento com FSH exógeno estimula a emergência da onda (BERGFELT et al., 1994a). O aumento transitório de FSH estimula todos folículos antrais que completaram sua fase de crescimento lenta. No entanto, estes não somente respondem como também dependem do FSH elevado para continuar sua proliferação celular e intensificar a esteroidogênese.

Após a emergência, os folículos crescem por dois ou três dias (GINTHER et al., 2003). A partir desse momento, um folículo pré selecionado continua seu crescimento (folículo dominante - FD), enquanto os demais se tornam atrésicos e entram em regressão (folículos subordinados); (LUCY et al., 1992). Esse processo fisiológico é conhecido como divergência ou desvio folicular. O final da fase de crescimento comum e o começo da divergência são sinônimos. O futuro folículo dominante emerge 6 horas antes que os outros folículos da onda e é maior do que estes no final da fase de crescimento comum (GINTHER et al., 2003a).

O pico da onda de FSH ocorre em média quando o maior folículo possui cerca de 5 mm, a concentração média então diminui com um intervalo aproximado de três dias entre o pico da concentração e o começo da divergência. A divergência é uma troca peculiar na taxa 
de crescimento entre o folículo dominante em desenvolvimento e os demais folículos (subordinados). Nas fêmeas Bos taurus, a divergência folicular ocorre 2,8 dias após a emergência da onda folicular, momento no qual o FD atinge 8,3 a 9,0 mm de diâmetro (SARTORI et al., 2001; 2004; BASTOS et al., 2010).

Apesar da expressão de receptores de LH no FD antes da divergência folicular (GINTHER et al., 2001), há estudos que demonstram a necessidade do FD apresentar crescimento adicional para adquirir capacidade ovulatória em ambas as espécies. Em vacas Bos taurus (diâmetro do FD no desvio de 8,3 a 9,0 mm), Sartori et al. (2001) verificaram que a capacidade ovulatória ocorre somente após os folículos alcançarem $10 \mathrm{~mm}$ de diâmetro.

O declínio do FSH é necessário para o estabelecimento da divergência. O aumento do FSH endógeno ou a administração em fase inicial da onda induzem vários folículos a se tornarem dominantes. Com a diminuição da concentração sérica de FSH começam a ocorrer mudanças nos folículos, incluindo produção reduzida de estrógenos, redução nos níveis de inibinas de elevado peso molecular e aumento de proteínas de ligação para o fator de crescimento semelhante à insulina (IGF) com baixo peso molecular, culminando com apoptose das células da granulosa (SUNDERLAND et al., 1996; MIHM et al., 1997). Neste ambiente, somente o folículo dominante é capaz de continuar a crescer e de produzir esteroides. O FSH estimula a produção de estradiol, activina A e inibina A (GLISTER et al., 2001). Estes fatores estimulados pelo FSH possuem papel intrafolicular na divergência. Ambos estradiol e inibina atuam de forma isolada (assim como sinergicamente) suprimindo a concentração sanguínea de FSH. A concentração sanguínea de estradiol começa a aumentar no começo da divergência folicular em bovinos (GINTHER et al., 2003a). A inibina (provavelmente a inibina-A) é produzida por múltiplos folículos antes da divergência e pelo folículo dominante após o início da divergência e suprime o FSH durante todo o período de declínio do FSH. O maior e o segundo maior folículo com diâmetros similares possuem concentração intrafolicular de estradiol semelhante durante a fase comum de crescimento. Com uma mudança aparente na diferença do diâmetro entre os dois maiores folículos. Aumento nas concentrações somente foi detectado em folículos com 7,6-7,7 mm em novilhas (GINTHER et al., 2003b). O aumento diferencial no futuro folículo dominante aumenta as concentrações sanguíneas de estradiol, promovendo aumento na expressão de genes para aromatase, de 3-beta-HSD, e de receptores para FSH e LH nas células da granulosa (BAO; GARVERICK, 1998). 
O sistema IGF está envolvido no crescimento celular e diferenciação e consiste de IGF-1, IGF-2, receptores de IGF, e uma família de proteínas ligantes (IGFBPs) e proteases de IGFBP (WEBB et al., 1999; FORTUNE et al., 2004).

Lammoglia et al. (1997) relataram que dietas ricas em ácidos graxos de cadeia longa aumentam a gliconeogênese hepática, devido a um aumento na produção de propionato no rúmen; os autores mencionaram, ainda, que o aumento na gliconeogênese tem sido associado a aumentos nas concentrações plasmáticas de insulina e IGF-I, que são hormônios conhecidos por influenciar a população de folículos médios.

O exato mecanismo de seleção e dominância ainda é pouco conhecido. Ginther et al. (2001) relataram que os receptores de LH são expressos nas células da granulosa do futuro folículo dominante 8 horas antes do início da divergência folicular. A presença de tais receptores permite o crescimento folicular mesmo em baixas concentrações de FSH. Apesar da expressão de receptores de LH no FD antes da divergência folicular (GINTHER et al., 2001), há estudos que demonstram a necessidade do FD apresentar crescimento adicional para adquirir capacidade ovulatória.

Portanto, em novilhas pré-puberes o crescimento folicular ocorre em ondas, sendo que cada onda é precedida de um pico sérico da concentração de FSH (ADAMS et al., 1992; ADAMS et al., 1994; FORTUNE, 2004). Entre a $6^{\text {a }}$ e a $24^{\text {a }}$ semana de idade existe um marcado, mas transitório aumento na concentração sanguínea de LH e FSH (EVANS et al., 1992; EVANS et al., 1994; HONARAMOOZ et al., 1999). Entretanto, entre 30 a 80 dias antes da primeira ovulação (EVANS et al., 1994; MELVIN et al., 1999), o aumento da frequência dos pulsos de LH resulta no aumento do diâmetro folicular e da concentração sérica de estradiol culminando com a primeira ovulação. Normalmente novilhas não expressam comportamento de cio antes da primeira ovulação, e o corpo lúteo é pequeno e pode ter meia vida curta (BERARDINELLI et al., 1979).

\subsection{RELAÇÃO NUTRIÇÃO E REPRODUÇÃO}

A alimentação exerce influência sobre a reprodução e os nutrientes apresentam mecanismos específicos de atuação sobre a eficiência reprodutiva. Os níveis nutricionais podem afetar o desenvolvimento e a função dos órgãos reprodutivos, além de acarretar alterações do funcionamento do sistema endócrino envolvido com a reprodução. Ao serem 
absorvidos, os nutrientes são direcionados a determinadas prioridades estabelecidas. São elas: metabolismo basal, atividades (andar, deitar etc.), crescimento, reservas corporais básicas, lactação, acúmulo de reservas corporais, ciclo estral e início da gestação. Por essa sequência de prioridades observa-se que o animal só direcionará nutrientes para a atividade reprodutiva quando todas as prioridades anteriores tiverem sido atendidas.

A reprodução é uma das primeiras e principais funções afetadas em situações de desequilíbrio nutricional, as quais são primariamente resultantes de falhas no ajuste do balanço entre a disponibilidade de nutrientes e sua exigência, tanto pelos animais em reprodução como por aqueles que irão ainda iniciar sua vida reprodutiva.

Dentre os fatores que exercem influência na reprodução, a nutrição tem um papel reconhecidamente importante por afetar diretamente aspectos da fisiologia e desempenho reprodutivo na fêmea bovina. Ainda há muita controvérsia sobre os efeitos do "flushing" nutricional ou incremento na ingestão de matéria seca (IMS) sobre a fertilidade e produção embrionária em ruminantes (DISKIN; MORRIS 2008; LEROY et al., 2008a; SANTOS et al., 2008). Por outro lado, como aspecto positivo, diversos trabalhos têm demonstrado resultados favoráveis com o uso de suplementos lipídicos sobre a função reprodutiva de fêmeas de corte e leite.

O efeito da nutrição na reprodução é um tópico amplamente discutido entre os pesquisadores. Vários estudos demonstram que a nutrição apresenta um papel importante na reprodução de ruminantes, pois alterações nutricionais podem influenciar diretamente o desempenho reprodutivo (BUTLER, 1998; BEAM; BUTLER, 1998; WEBB et al., 1999; LUCY, 2000, 2003; ARMSTRONG et al., 2003; WEBB et al., 2004; SANTOS et al., 2008).

Nos ruminantes, a nutrição influencia a fertilidade diretamente através do fornecimento de nutrientes específicos, que são necessários para os processos de desenvolvimento do folículo, ovulação, maturação oocitária, fertilização, sobrevivência embrionária e o estabelecimento da gestação; e, indiretamente, atuando sobre as concentrações circulantes dos hormônios e outros metabólitos sensíveis aos nutrientes que são necessários para o sucesso destes processos (ROBINSON et al., 2006).

A nutrição pode influenciar a síntese e liberação dos hormônios reprodutivos necessários para o desenvolvimento folicular e subsequente ovulação. A interação entre a liberação de gonadotrofinas e fatores intrafoliculares que interferem no desenvolvimento folicular, estão diretamente ligados ao estado nutricional (WEBB et al., 2004).

A ingestão de nutrientes age em vários níveis dentro do eixo hipotálamohipófisegônada e afeta fatores de crescimento de origem sistêmica ou local que controlam 
direta ou indiretamente a função ovariana e a produção embrionária (ARMSTRONG et al., 2001; GONG, 2002). Acredita-se que o tipo e/ou quantidade da dieta fornecida aos animais antes de iniciar os programas de superestimulação ovariana tem forte influência sobre a resposta superovulatória e qualidade embrionária (YAAKUB et al., 1999).

A energia é o fator que mais afeta a reprodução de fêmeas bovinas. A ingestão insuficiente de energia está correlacionada com baixo desempenho reprodutivo, atraso na idade à puberdade, atraso no intervalo da primeira ovulação e cio pós-parto e redução nas taxas de concepção e de prenhez em vacas de corte e de leite (SANTOS et al., 2004). Por outro lado, vários estudos mostraram que dietas altamente energéticas diminuem a resposta aos protocolos de superovulação, diminuem a produção embrionária e alteram a expressão de genes importantes para o desenvolvimento embrionário. O mecanismo pelo qual isto ocorre ainda não está claro, mas acredita-se que esteja relacionado com a produção de ovócitos com qualidade comprometida (DUNNE et al., 1999; YAAKUB et al., 1999; SANTOS et al., 2008).

Portanto os níveis nutricionais podem afetar diretamente o desenvolvimento e a função dos órgãos reprodutivos, bem como, indiretamente através de alterações do funcionamento do sistema endócrino envolvido com a reprodução. Os potenciais sítios de ação da nutrição sobre a função ovariana são no hipotálamo, via síntese e liberação de GnRH, na pituitária anterior, mediante controle da síntese e liberação de FSH, LH e no ovário, pela regulação do crescimento do folículo e síntese de esteróides.

Existem evidências que hormônios metabolizados como o $(\mathrm{GH})$ - hormônio do crescimento, insulina, somatomedina (IGF-I) e suas proteínas ligadoras (IGFBPs), leptina, neuropeptínogenio Y e peptídeos opióides endógenos (POE), tem um importante papel no controle do desenvolvimento folicular e são mediadores dos efeitos da ingestão e ou do balanço energético sobre a fertilidade da vaca. Recentemente diversas pesquisas tem demonstrado que os metabolismos hormonais exercem efeitos diretos sobre a atividade ovariana, funcionando como sinais nutricionais, destacando-se entre eles o $\mathrm{GH}$, insulina e IGF-I.

O IGF-I ou somatomedina é produzido pelo fígado e atua sobre os principais tipos de células que regulam o metabolismo de carboidratos, gorduras, proteínas e tem sido proposto como um regulador hipofisário do crescimento folicular ovariano, além de atuar regulando a secreção pulsátil de GnRH e LH, podendo aumentar o número de receptores para o LH (FERREIRA et al., 2002). Especificamente, não existe exigência de nenhum nutriente para a reprodução que não atue sobre outras funções fisiológicas normais do organismo, tornando-se 
difícil determinar as funções específicas e mecanismos pelos quais a nutrição pode afetar as funções reprodutivas (ROCHE; DISKIN, 1994). São vários os relatos da influência nutricional sobre o desempenho reprodutivo, mostrando a relação íntima entre fertilidade, condição corporal e estado nutricional nas fêmeas de ruminantes (ROBINSON, 1996).

Há evidências de que o prejuízo do excesso de energia na dieta sobre o desenvolvimento embrionário inicial esteja relacionado a alterações no crescimento folicular e na divisão meiótica final do oócito (LEROY et al., 2008a). Porém, ainda não foram estabelecidas com acurácia quais alterações do fluido folicular que eventualmente possam modificar o conteúdo do citoplasma do oócito, reduzindo sua viabilidade. Os hormônios metabólicos extra ovarianos (insulina e leptina) e fatores de crescimento locais estão envolvidos nos mecanismos pelos quais a dieta poderia interferir na qualidade dos oócitos (WEBB et al., 2004). Concentrações adequadas de insulina e IGF-1 são importantes para o crescimento folicular e maturação oocitária (LANDAU et al., 2000; ARMSTRONG et al., 2002a). No entanto, dietas que reduzem a concentração de IGFBP e, consequentemente, aumentam a disponibilidade de IGF-1 livre intrafolicular podem influenciar diretamente a qualidade do oócito (ARMSTRONG et al., 2001). Porém, o excesso de IGF-1 biodisponível pode apresentar efeito negativo sobre a competência oocitária (ARMSTRONG et al., 2002a).

De fato, o estado nutricional e metabólico podem alterar os padrões de crescimento folicular, parâmetros endócrinos, concentrações circulantes de esteróides e atividade secretória do útero de bovinos (ROBINSON et al., 2006; LEROY et al., 2008a). Dessa forma, a ingestão apropriada de nutrientes é fundamental para o adequado desempenho reprodutivo em bovinos. Porém, essa relação é complexa e as respostas são frequentemente inconsistentes e variáveis (BOLAND et al., 2001).

Ezzo e Hegazy (1999) constataram um aumento na porcentagem de novilhas (80,0 vs $33,3 \%$ ) com atividade ovariana durante períodos de alimentação com suplementação lipídica $(5,8 \%)$ quando comparadas com o grupo controle $(2,3 \%)$, sugerindo que este aumento pode ser atribuído a uma melhora da foliculogênese e/ou ao aumento da secreção do LH. Portanto, o potencial reprodutivo é influenciado pelos efeitos nutricionais a curto e a longo-prazo (SCARAMUZZI; MURRAY, 1994).

\subsection{SUPLEMENTAÇÃO DE ÁCIDOS GRAXOS POLIINSATURADOS}


Os lipídeos são compostos orgânicos insolúveis em água, mas solúveis em solventes orgânicos e que desempenham importantes funções bioquímicas e fisiológicas nos tecidos animais e vegetais (CHURCH; POND, 1977).

O lipídeo é utilizado na dieta de ruminantes principalmente para aumentar a concentração de energia e melhorar o desempenho animal (SANTOS, 1998). O consumo de lipídios pelos ruminantes é limitado na natureza (WILLIAMS, 2001), com as dietas contendo aproximadamente 2 a $3 \%$ de ácidos graxos de cadeia longa de origem vegetal, sendo predominantemente poli-insaturados (SANTOS, 1998). Nas forragens, as gorduras estão presentes, principalmente, na forma de fosfolipídios e glicolipídios, enquanto nos grãos encontram-se na maior parte como triglicerídeos (VAN SOEST, 1994).

Os lipídeos, por conter 2,25 vezes mais energia por unidade de peso em relação aos carboidratos e proteínas (valores dos combustíveis fisiológicos estabelecidos por Atwater, conforme DAVIS, 1993), apresentam alta concentração de energia.

A adição de lipídeo à dieta é uma opção para elevar a densidade energética, sem aumentar a ingestão de carboidratos não estruturais e sem comprometer a ingestão de fibras (SALLA et al., 2003). Além disso, os átomos de carbono dos ácidos graxos são quimicamente mais reduzidos que aqueles dos açúcares e, portanto, a oxidação dos triacilgliceróis libera, proporcionalmente, uma quantidade de energia, aproximadamente, duas vezes maior que a liberada pelos carboidratos (FIALHO; OLIVEIRA, 2005).

Dentre os nutrientes exigidos por vacas em reprodução, a energia é o principal, e seu fornecimento inadequado na dieta tem efeitos deletérios sobre a eficiência reprodutiva de fêmeas bovinas (SANTOS, 1998; LAMB, 2003).

A suplementação de lipídeos tem sido estudada por causar efeitos benéficos na reprodução, como o aumento na concentração sanguínea de progesterona, aumento do tamanho do folículo ovulatório, número de folículos ovarianos, modulação do corpo lúteo, taxa de concepção e gestação (STAPLES et al., 1996).

A teoria da diminuição do metabolismo dos esteróides é atualmente uma das mais discutidas para explicar as maiores concentrações de esteroides na suplementação lipídica. Hawkins et al. (1995) avaliaram o mecanismo pelo qual a inclusão de gordura na dieta aumenta a concentração de progesterona circulante, através do fornecimento de sais de cálcio de ácidos graxos de cadeia longa, iniciando 100 dias antes do parto. A concentração de progesterona foi maior para novilhas de corte mantidas nesta dieta, porém as concentrações luteais de progesterona foram similares entre os grupos, sugerindo que não houve diferença na taxa de secreção de progesterona. Por outro lado, o tempo requerido para a queda pela metade 
das concentrações circulantes de progesterona, após ovariectomia, foi maior nas novilhas suplementadas com gordura.

A energia é o nutriente que mais afeta a reprodução em fêmeas bovinas, e sua ingestão insuficiente está correlacionada com baixo desempenho reprodutivo, atraso na idade à puberdade, aumento no intervalo da primeira ovulação e cio pós-parto, e redução nas taxas de concepção e de prenhez (LAMB, 2003; SANTOS, 2005).

Como já citado acima, a inclusão de lipídeos na dieta pode melhorar o desempenho reprodutivo de ruminantes. Estes efeitos podem ser dependentes do perfil de ácidos graxos da fonte de gordura (OLDICK et al., 1997) e, também, da relação de causa e efeito entre a progesterona e o colesterol. A dieta rica em lipídios aumenta as concentrações de colesterol sanguíneo e, este é um dos precursores de progesterona (LAMMOGLIA et al., 2000).

Independentemente de sua contribuição energética, os ácidos graxos podem modificar algumas vias específicas e influenciar o metabolismo de alguns hormônios (esteroides e eicosanoides) que modulam os processos metabólicos nos ovários e no útero, além de exercer efeitos diretos na transcrição de genes que codificam proteínas essenciais à reprodução. Os mecanismos pelos quais a suplementação melhora o desempenho reprodutivo parecem envolver, principalmente, aumentos na capacidade funcional do ovário, na concentração de progesterona circulante e na vida útil do corpo lúteo (CL) (WILLIAMS, 1990; RYAN et al., 1995; LAMMOGLIA et al., 1996³ , apud SATURNINO; AMARAL, 2005; BEAM; BUTLER, 1999; MATTOS et al., 2000; ARMSTRONG et al., 2001; BELLOWS et al., 2001; BOKEN et al., 2005), como já mencionado anteriormente.

Existem várias fontes de lipídeos que podem ser utilizadas na dieta dos ruminantes. Essas se estendem desde o óleo de soja (VARGAS et al., 2001) até fontes protegidas de origens vegetais ou animais (HIGHTSHOE et al., 1991), e sementes inteiras de oleaginosas (TALAVERA; PARK; WILLIANS, 1985; WILLIAMS, 1989).

As sementes de oleaginosas são bastante utilizadas pelas altas concentrações de lipídios e por apresentarem características interessantes com relação à taxa de liberação do óleo, o qual é liberado de forma mais lenta, através da mastigação, chegando em pequenas frações ao ambiente ruminal (COPPOCK; WILKS, 1991). Diversos tipos de lipídeos

\footnotetext{
${ }^{3}$ LAMMOGLIA, M.A.; WILLARD, S.T.; OLDHAM, J.R. Effects of dietary fat and season on steroid hormonal profiles before parturition and on hormonal, cholesterol, triglycerides, follicular patterns and postpartum reproduction in Brahman cows. Journal of Animal Science, v.74, p.2253-2262, 1996.
} 
suplementares são utilizados na alimentação de vacas de leite, sendo bastante variável o perfil de ácidos graxos dos mesmos (SANTOS, 1998).

Lucy et al. (1991), sincronizando o ciclo estral de vacas no $25^{\circ}$ dia pós-parto, observaram aumento no número de folículos pequenos (<5 mm) e grandes $(>10 \mathrm{~mm})$ quando foram incluídos lipídeos na dieta. Fato também constatado por Garnsworthy et al. (2008), suplementando vacas de leite com sais de cálcio de óleo de palma e, por Nogueira (2008), suplementando novilhas com diferentes fontes lipídicas. Um aumento no número de folículos menores pode refletir em uma seleção maior de estruturas disponíveis para desenvolvimento posterior, e um maior número de folículos grandes pode indicar um processo de seleção alterado e maior disponibilidade de estruturas para ovular (SANTOS, 1998).

Robinson et al. (2002) também verificaram aumento significativo no número de folículos médios $(5-10 \mathrm{~mm})$ na primeira e na segunda onda folicular após a sincronização do estro em vacas Holandesas que receberam suplementação com ácidos linoleico e linolênico em comparação às vacas não suplementadas. Os autores também verificaram um aumento no tamanho do primeiro folículo dominante nos animais tratados, em relação ao grupo-controle.

Alterando o teor de ácidos graxos total da dieta ocorre alteração sobre a distribuição de ácidos graxos nos tecidos reprodutivos (BILBY et al., 2006). A suplementação dietética em novilhas de corte com uma elevada inclusão de óleo de peixe (fonte rica de ácidos graxos $\omega$-3) aumentou significativamente a quantidade de AGPIs $\omega 3$ totais e a relação $\omega 3$ : $\omega 6$ no fluido folicular (CHILDS et al., 2008), sendo que esta mudança foi fortemente correlacionado com o aumento dos níveis de $\omega 3$ no plasma sanguíneo. Tal alteração do perfil dos ácidos graxos no fluido folicular demonstrou que há influência desses sobre o desenvolvimento de oócitos.

No entanto, em termos de análise qualitativa e quantitativa de ácidos graxos e teor de lipídios, os dados sobre oócitos ainda são limitados, bem como o conhecimento sobre o metabolismo lipídico, durante a maturação do oócito (KIM et al., 2001; STURMEY et al., 2009). AGNE adicionados durante a maturação in vitro de oócitos de bovinos tiveram efeitos transitórios sobre a qualidade embrionária. Marei et al. (2009) relataram que o ácido linolênico (18:3 $\omega 3$ ) pode melhorar a maturação do oócito bovino e do potencial desenvolvimento deste, melhorando a qualidade do blastocisto. Ácidos araquidônico (C20: 4

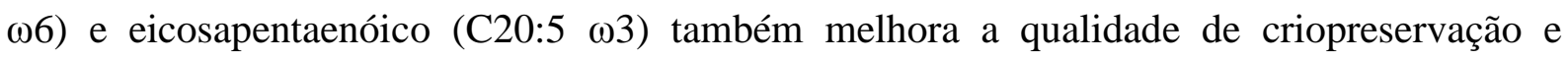
embrionária (MARQUES et al., 2007). 
Portanto, as principais famílias de ácidos graxos polinsaturados (AGPs) que afetam a fertilidade são $\omega$-3 e $\omega$-6. O ácido linoleico dietético é um dos representantes da família $\omega$ 6, o qual é convertido em ácido aracdônico, precursor das prostaglandinas dienoicas, como a PGF2 $\alpha$. Por outro lado, o ácido linolênico ( $(\omega-3)$ é convertido a ácido eicosapentaenoico precursor das prostaglandinas trienoicas, como PGF3 $\alpha$. Deste modo, a produção das prostaglandinas pode ser manipulada de acordo com a proporção de ácidos graxos presentes na dieta. Os AGPs podem elevar a fertilidade em bovinos por diferentes caminhos. Nos ovários, há relatos de efeito dos ácidos graxos sobre o número e tamanho de folículos ovarianos (LUCY et al., 1991; ROBINSON et al., 2002; BILBY et al., 2006), tamanho do CL (RAES et al., 2004; BILBY et al., 2006) e na qualidade oocitária (KIM et al., 2001; ZERON et al., 2002). Além disso, outros estudos também observaram influência de dietas contendo ácidos graxos sobre a qualidade embrionária (KOJIMA et al., 1997; CHILDS et al., 2008a; CERRI et al., 2009b) e a concentração circulante de prostaglandinas e hormônios esteroides (RYAN et al., 1992; THOMAS et al., 1997; PETIT et al., 2002; CHILDS et al., 2008b).

\subsubsection{Fontes de ácidos graxos $\Omega 3$ e $\Omega 6$ na alimentação de novilhas}

\subsubsection{Semente de linhaça ( $\omega$ 3)}

A semente de linhaça (Linum usitatissimum) é fonte rica em lipídeos, além de ter um teor de proteína bruta acima de $20 \%$ da MS. Seu óleo possui altos teores de ácido linolênico

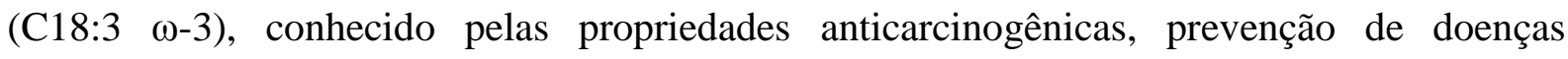
cardiovasculares e aumento da capacidade visual em humanos (PONNAMPALAM et al., 2001; SCOLLAN, 2001; PETIT, 2002). Segundo Petit (2002), a ingestão de linhaça por vacas leiteiras pode resultar em um aumento na concentração dos ácidos graxos ômega-3 no leite.

A semente de linhaça, como o grão de soja, tradicionalmente na nutrição animal se enquadra como alimento proteico, mas seu grande conteúdo energético advindo das altas concentrações de ácidos graxos torna sua importância nutricional muito maior que a de meros alimentos proteicos.

O uso da linhaça da nutrição de vacas leiteiras vem sendo difundido principalmente a partir dos anos 2000, quando uma série trabalhos de pesquisadores canadenses retrataram 
os benefícios da linhaça como alimento energético e modulador do desempenho reprodutivo e imunológico (PETIT et al., 2004, 2007).

A linhaça em sua forma de semente oleaginosa destaca-se pelo equilíbrio nutricional, contento $24,6 \%$ de proteína bruta, 39,1\% de extrato etéreo, $17,7 \%$ de fibra em detergente neutro e um conteúdo energético de $6500 \mathrm{kcal}$ de energia bruta (VALADARES FILHO et al., 2006).

A influência da semente de linhaça na nutrição de vacas leiteiras parece ser mais evidente quando observamos os seus efeitos como agente nutracêutico na modulação da eficiência reprodutiva e da função imune de vacas. As altas concentrações de ácido linolênico reduzem as concentrações de prostaglandina e com maiores diâmetros do corpo lúteo no período de serviço dos animais (PETIT et al., 2002). As baixas concentrações de $\mathrm{PGF}_{2} \alpha$ contribuem com melhores taxas de concepção de vacas leiteiras pela influência negativa deste hormônio na manutenção da gestação (WILTBANK et al., 2006).

\subsubsection{Grão de soja ( $\omega$ 6)}

Entre as diferentes fontes de proteína e gordura disponíveis a serem utilizadas na alimentação de ruminantes no Brasil, o grão de soja se destaca pela grande disponibilidade e custo compatível com seu rico conteúdo em nutrientes.

A soja é um grão rico em proteínas, cultivado em todo mundo como fonte de alimento para humanos e animais, e pertence à família Fabaceae (leguminosa). Destaca-se entre os alimentos proteicos de origem vegetal como fonte alternativa de proteína e energia, sendo considerada semente de oleaginosa mais disponível no mundo, podendo ser usada na alimentação dos ruminantes na sua forma original (crua) ou processada (CORRÊA, 2007). Considera-se que resultados obtidos com grão de soja cru (moído grosseiramente, peletizado ou macerado) são iguais ou melhores quando comparados aos de processos de aquecimento, extrusão ou esfarelamento (EARLEYWINE, 1989). Quanto ao custo, isso poderia acarretar vantagem econômica, pois em regiões produtoras de leite brasileiras, na maioria das vezes, o preço do grão de soja é menor que o do farelo de soja.

Uma das vantagens do grão de soja integral como fonte lipídica para ruminantes é a lenta liberação de lipídios no rúmen, onde a capacidade de hidrogenação da microbiota ruminal não é excedida, impedindo possível redução na degradação da fibra pelo efeito 
negativo que ácidos graxos insaturados podem causar sobre as bactérias fibrolíticas (COPPOCK; WILKS, 1991; PALMQUIST, 1991). Isso ocorre em sementes de oleaginosas porque a maioria dos lipídios encontra-se no germe e, portanto, há necessidade da degradação da parede celular para que a hidrólise se inicie.

A utilização do grão de soja cru ou integral na alimentação de ruminantes não é recente. Por apresentar composição de aproximadamente 39,2\% de proteína bruta, 19,2\% de extrato etéreo e 84,5\% de nutrientes digestíveis totais (NRC, 2001; VALADARES FILHO et al., 2006), o grão de soja tem sido utilizado na alimentação de ruminantes com o propósito de ser fonte de proteína, especialmente pela alta concentração e adequado valor biológico deste nutriente. Também, pelo elevado teor de extrato etéreo, pode ser considerado alimento fonte lipídica para ruminantes. O grão de soja integral ainda se destaca pelo elevado teor de ácidos graxos insaturados e pela aceitação pelos animais (PALMQUIST, 1978; PALMQUIST, 1991; RABELO et al., 1996; PALMQUIST; MATTOS 2006).

O grão de soja é rico em ácido linoleico (C18:2 $\omega-6)$, um ácido graxo essencial e que atua como, dos precursores na síntese de prostaglandina- $\mathrm{F}_{2 \alpha}\left(\mathrm{PGF}_{2 \alpha}\right)$. Sua adição na dieta de fêmeas bovinas, por meio de fontes lipídicas suplementarres pode alterar o padrão de secreção desse hormônio. Lucy et al. (1991) argumentaram que os efeitos de lipídios sobre a dinâmica folicular de vacas no pós-parto são devido à maior síntese de $\mathrm{PGF}_{2 \alpha}$ quando maiores quantidades de ácido linoleico atingem o intestino delgado.

O controle da secreção de PGF $_{2 \alpha}$ através da alimentação com ácidos graxos poliinsaturados pode melhorar a fertilidade pela redução das perdas embrionárias devido à luteólise precoce (AYALON, 1978; MAURER; CHENAULT, 1983; THATCHER et al., ${ }^{4}$ 1994, apud MATTOS et al., 2000). Randel et al. (1990) afirmaram que a PGF $_{2 \alpha}$ tem efeito positivo no desempenho reprodutivo pós-parto e no crescimento folicular.

\subsection{INFLUÊNCIA DOS ÁCIDOS GRAXOS DA FAMÍLIA $\Omega 3$ E $\Omega 6$ NO DESEMPENHO DE NOVILHAS}

\subsubsection{Perfil metabólico}

\footnotetext{
${ }^{4}$ THATCHER, W. W.; STAPLES, C. R.; DANET-DESNOYERS, G.; OLDICK, B.; SCHMITT, E. P. (1994) Embryo health and mortality in sheep and cattle. Journal of Animal Science, v. 72, n. 16, 1994. Supplement 3.
} 
A avaliação do status nutricional de um rebanho ou animal pode ser realizada mediante a determinação de alguns metabólitos sanguíneos. A utilização do perfil metabólico em animais de produção atua como um método auxiliar na avaliação de rebanhos com diferentes índices produtivos e reprodutivos, atuando também como uma importante ferramenta no diagnóstico clínico de doenças do metabolismo. Como se tem observado, os metabólitos sanguíneos têm sido utilizados principalmente como auxiliares do diagnóstico clínico, mas a partir do surgimento do termo perfil metabólico, a química sanguínea passou a ter maior interesse no campo zootécnico. Perfil metabólico foi o termo empregado por Payne et al. (1970), se referindo ao estudo de componentes hemato-bioquímicos específicos em vacas leiteiras, com o intuito de avaliar, diagnosticar e prevenir transtornos metabólicos e servindo também como indicador do estado nutricional.

O número de variáveis potencialmente mensuráveis no perfil metabólico é ilimitado. Porém, na prática, opta-se por parâmetros que se tenha conhecimento sobre a fisiologia e a bioquímica, o que permite a interpretação dos resultados. Além disso, é importante que o equipamento e a técnica para a determinação sejam economicamente viáveis, e que os parâmetros possuam valores de referência confiáveis.

Uma das maiores dificuldades da utilização desta ferramenta é a sua interpretação, devido à falta de valores de referência adequados. Há uma variação de resultados obtidos, dependendo da idade do animal, raça, estado fisiológico, clima, época do ano, entre outros. Ou seja, por isso a dificuldade de se ter um padrão de comparação que possa garantir a melhor interpretação dos resultados. Segundo Dirksen e Breitner (1993), os componentes bioquímicos sanguíneos mais comumente determinados no perfil metabólico representam as principais vias metabólicas do organismo, das quais a glicose, o colesterol e o betahidroxibutirato representam o metabolismo energético; a ureia, a hemoglobulina, as globulinas, a albumina e as proteínas totais representam o metabolismo proteico (WITTWER; CONTRERAS, 1980). Adicionalmente são estudados colesterol total e suas frações LDL, VLDL e HDL, representando o lipidograma completo (GONZÁLEZ, 1997).

A glicose é o substrato metabólico mais importante para o adequado funcionamento dos processos reprodutivos em bovinos (SHORT; ADAMS, 1988), sendo a principal fonte de energia para o sistema nervoso central. A sua inadequada disponibilidade reduz a liberação hipotalâmica de GNRH (KEISLER; LUCY, 1996; WETTEMAN et al., 2003). Em vacas de corte, há grande variação na concentração de glicose, no entanto, alguns pesquisadores 
sugerem que o papel da glicose como mediador nutricional do controle reprodutivo não seja um fator decisivo, apenas um indicador de tolerância (KEISLER; LUCY, 1996).

Apesar de a glicose ser o metabólito de eleição para avaliar o status energético dos ruminantes, trabalhos têm demonstrado certa contrariedade nos resultados, uma vez que mecanismos homeostáticos que controlam a glicemia tornam difícil estabelecer uma clara relação entre estado nutricional e níveis de glicose, pois além de grande parte dos tecidos utilizarem ácidos graxos livres (AGL) e corpos cetônicos como fonte energética, o fígado destes animais possui alta função neoglicogênica. Downie e Gelman (1976) verificaram, em um rebanho bovino de corte, relações de glicose sanguínea com o peso corporal e fertilidade; ao fornecer três níveis de energia na dieta, foi verificado que à medida que a glicemia aumentava, melhorava a fertilidade, enquanto baixos níveis de glicose levavam a infertilidade.

A avaliação do colesterol sanguíneo também auxilia no desempenho produtivo e reprodutivo dos ruminantes. Ele pode influenciar na performace reprodutiva dos ruminantes, por ser precursor de hormônios esteroides importantes como a progesterona. Baixos níveis de colesterol diminuem sua concentração no ovário, podendo prejudicar a produção de hormônios esteroides (GODOY et al., 2004).

A avaliação do perfil metabólico ligada ao status nutricional e desempenho reprodutivo tem despertado o interesse de diversos pesquisadores atualmente, enfocando principalmente as maiores exigências nutricionais associadas com o melhor desempenho produtivo e reprodutivo.

Bu et al. (2010) ao estudarem o efeito de óleos ricos em ácido linoleico (óleo de soja), ácido linolênico (óleo de semente de linhaça) ou uma combinação dos dois óleos encontraram concentrações de colesterol, fosfolipídios, colesterol de lipoproteína de baixa densidade (LDL) e AGNE no sangue aumentadas em relação a dieta controle. O aumento nas concentrações desses parâmetros foi similar em estudos anteriores (GRUMMER; CARROL, 1991; PETIT et al., 2002; PETIT, 2002).

Ao avaliar as concentrações sanguíneas do perfil metabólico há necessidade de considerar as características do rebanho, a localização geográfica e o estado fisiológico dos animais, uma vez que estes componentes sofrem variações decorrentes da fisiologia e do manejo ao qual o animal está submetido (SATRADIOTTI JÚNIOR; COSÉR, 2012). A adequada interpretação dos valores encontrados no perfil metabólico sanguíneo depende do conhecimento da fisiologia e bioquímica animal, além da fonte e a função de cada um dos metabólitos avaliados. Os métodos utilizados na sua determinação, também, são de suma importância na definição do perfil metabólico (WITTWER, 2000). 


\subsection{INFLUÊNCIA DOS ÁCIDOS GRAXOS $\Omega 3$ E $\Omega 6$ NA QUALIDADE OOCITÁRIA E EMBRIONÁRIA DE NOVILHAS}

A dieta pode regular a fertilidade em fêmeas bovinas tanto por efeitos imediatos quanto latentes (COYNE et al., 2011). A suplementação com gordura tem melhorado o desempenho reprodutivo de bovinos com aptidão para corte e leite (BILBY et al., 2006), independente de sua contribuição com o aumento da densidade de energia, já que PUFAs específicos constituintes dessa dieta podem estimular a função ovariana (FUNSTON, 2004).

Uma grande variedade de dietas tem mostrado afetar não somente o crescimento folicular, mas também a qualidade do oócito (ARMSTRONG et al., 2001; BOLAND et al., 2001).

A suplementação lipídica é uma prática comum para aumentar a densidade energética da dieta. Além de fornecer calorias, a gordura possui efeito direto na reprodução através do tipo de ácido graxo presente (FUNSTON, 2004; RAES et al., 2004). Os ácidos graxos poliinsaturados (AGP) que compõem os ovócitos e embriões (MCEVOY et al., 2000; KIM et al., 2001; FERREIRA et al., 2010) fornecem energia para os processos relacionados à maturação e competência ovocitária (KIM et al., 2001) e para o desenvolvimento embrionário (WATHES et al., 2007). Além disso, fazem parte da membrana plasmática, alterando sua fluidez que é essencial para o desenvolvimento celular durante e após a fecundação (MCEVOY et al., 2000; FOULADI-NASHTA et al., 2007), bem como afetam a resistência celular à técnica de criopreservação (CLANDININ et al., 1991; ZERON et al., 2002).

Ácidos graxos poliinsaturados na dieta podem influenciar positivamente a reprodução de vacas leiteiras pela alteração do folículo ovariano e função do corpo lúteo, por melhorar o status energético e pelo aumento dos precursores das sínteses dos hormônios reprodutivos como os esteróides e as prostaglandinas (STAPLES; BURKE; THATCHER, 1998; MATTOS et al., 2000, 2002). O efeito positivo dos lipídeos sobre a função reprodutiva seja principalmente devido aos ácidos graxos poliinsaturados (AMBROSE; KASTELIC, 2003; PETIT, 2003).

O ácido linoleico (C18:2 $\omega 6)$ é um AG essencial necessário para a função normal da reprodução em mamíferos (BURR; BURR, 1930). À medida que há maior ingestão deste AG há maior disponibilidade deste precursor para a síntese endógena de ácido araquidônico (C20:4 w6) o que se pode resultar em aumento de incorporação de ácido araquidônico em 
membranas das células do endométrio resultando em ampla síntese de PGF2 $\alpha$ (MATTOS et al., 2003).

Todavia, foi observado em estudos recentes que a suplementação da dieta com ácido linoleico ou linolênico não altera o tamanho do folículo dominante (AMBROSE et al., 2006), o diâmetro e a taxa de crescimento do folículo pré-ovulatório (CHILDS et al., 2008b; CERRI et al., 2009).

Também, a ovulação de um folículo dominante maior, resultou em um corpo lúteo (CL) maior em novilhas leiteiras, vacas secas ou em lactação (SARTORI et al., 2002). Porém, a formação de um CL maior pode também ser decorrente de efeitos diretos dos PUFAs nessa estrutura, como o maior acúmulo de lipídeos nas células luteais observado após microscopia eletrônica. Dessa forma, pode-se esperar que ocorra uma maior produção de progesterona (P4) (BILBY et al., 2006). Em estudos anteriores, a suplementação alimentar com ácido linoléico ou linolênico não alterou o tamanho do corpo lúteo e a concentração plasmática de $\mathrm{P} 4$ (AMBROSE et al., 2006; CHILDS et al., 2008b).

O oócito após a fecundação, além de contribuir com o material genético, fornece todos os componentes necessários para desenvolvimento inicial do zigoto. No citoplasma do oócito, proteínas e organelas são fundamentais para o crescimento embrionário inicial (SCHULTZ, 2002). Assim, o gameta feminino é importante não apenas para a formação do genoma, mas também no fornecimento de ferramentas necessárias para replicação celular. Diante de tais considerações, quaisquer alterações citoplasmáticas no oócito podem influenciar o crescimento subsequente do embrião (SCHULTZ, 2002).

A restrição alimentar em novilhas pode afetar adversamente parâmetros morfológicos e funcionais do desenvolvimento folicular, como tamanho, taxa de crescimento e atividade esteroidogênica do folículo dominante (BEAM; BUTLER, 1999; RHODES et al., 1996). Inversamente, a prática de flushing (aumento da ingestão de energia por curtos períodos) têm sido responsável por melhorar o desenvolvimento do folículo ovariano e diminuir a percentagem de folículos atrésicos nos ovários (MAURASSE et al., 1985). Entretanto, alguns autores não têm encontrado aumento na população folicular ou melhoras na resposta de produção de embriões quando novilhas e vacas foram suplementadas com níveis aumentados de energia na dieta (BASTOS et al., 2007a,b).

\subsubsection{Qualidade oocitária}


Crescimento do folículo ovariano pode ser influenciado pelo estado nutricional e metabólico (GUTIÉRREZ et al., 1997; DISKIN et al., 2003). Este efeito é mediado por alterações nos metabólitos plasmáticos e hormônios, tais como a insulina e fator de crescimento semelhante à insulina -1 (IGF-1) (ARMSTRONG et al., 2001; FERGUSON et al., 2006) e / ou fatores de hormônios de crescimento presentes no fluido folicular (LANDAU et al., 2000). A dieta pode afetar também a morfologia dos oócitos (O'CALLAGHAN et al., 2000), a capacidade de desenvolvimento de oócitos e a produção de embriões.

Ácidos graxos poliinsaturados constituem a maior parte do conteúdo de ácidos graxos do fluido folicular de folículos grandes e pequenos (HOMA et al., 1992). Alterando o teor de ácidos graxos total da dieta ocorre alteração sobre a distribuição de ácidos graxos nos tecidos reprodutivos (BILBY et al., 2006). A suplementação dietética em novilhas de corte com uma elevada inclusão de óleo de peixe (fonte rica de ácidos graxos $\omega$-3) aumentou significativamente a quantidade de AGPIs $\omega 3$ totais e a relação $\omega 3$ : $\omega 6$ no fluido folicular (CHILDS et al., 2008), sendo que esta mudança foi fortemente correlacionado com o aumento dos níveis de $\omega 3$ no plasma sanguíneo. Tal alteração do perfil dos ácidos graxos no fluido folicular demonstrou que há influência desses sobre o desenvolvimento de oócitos.

O oócito após a fecundação, além de contribuir com o material genético, fornece todos os componentes necessários para desenvolvimento inicial do zigoto. No citoplasma do oócito, proteínas e organelas são fundamentais para o crescimento embrionário inicial (SCHULTZ, 2002). Assim, o gameta feminino é importante não apenas para a formação do genoma, mas também no fornecimento de ferramentas necessárias para replicação celular. Diante de tais considerações, quaisquer alterações citoplasmáticas no oócito podem influenciar o crescimento subsequente do embrião (SCHULTZ, 2002).

Há evidências de que o prejuízo do excesso de energia na dieta sobre o desenvolvimento embrionário inicial esteja relacionado a alterações no crescimento folicular e na divisão meiótica final do oócito (LEROY et al., 2008a). Porém, ainda não foram estabelecidas com acurácia quais alterações do fluido folicular que eventualmente possam modificar o conteúdo do citoplasma do oócito, reduzindo sua viabilidade.

No entanto, em termos de análise qualitativa e quantitativa de AG e teor de lipídios, os dados sobre oócitos ainda são limitados, bem como o conhecimento sobre o metabolismo lipídico, durante a maturação do oócito (KIM et al., 2001; STURMEY et al., 2009). AGNE adicionados durante a maturação in vitro de oócitos de bovinos tiveram efeitos transitórios sobre a qualidade embrionária. Marei et al. (2009) relataram que o ácido linolênico (18:3 (13) pode melhorar a maturação do oócito bovino e do potencial desenvolvimento deste, 


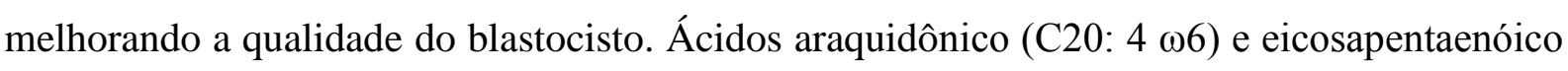
(C20: 5 w3) também melhorou a qualidade de criopreservação e embrionária (MARQUES et al., 2007).

Os hormônios metabólicos extra ovarianos (insulina e leptina) e fatores de crescimento locais estão envolvidos nos mecanismos pelos quais a dieta poderia interferir na qualidade dos oócitos (WEBB et al., 2004). Concentrações adequadas de insulina e IGF-1 são importantes para o crescimento folicular e maturação oocitária (LANDAU et al., 2000; ARMSTRONG et al., 2002a). No entanto, dietas que reduzem a concentração de IGFBP e, consequentemente, aumentam a disponibilidade de IGF-1 livre intrafolicular podem influenciar diretamente a qualidade do oócito (ARMSTRONG et al., 2001). Porém, o excesso de IGF-1 biodisponível pode apresentar efeito negativo sobre a competência oocitária (ARMSTRONG et al., 2002a).

\subsubsection{Qualidade embrionária}

Empregada há algumas décadas, a PIV de embriões bovinos é uma biotecnologia bastante difundida e vem sendo aplicada comercialmente com sucesso. No relatório da Sociedade Internacional de Transferência de Embriões (THIBIER, 2008), o Brasil foi classificado como o primeiro país em volume de produção de embriões obtidos in vitro. Atualmente, o principal obstáculo para a expansão comercial da PIV no Brasil é a possibilidade de obtenção de taxas de prenhez satisfatórias a partir de embriões criopreservados (NOGUEIRA, 2012).

Alguns estudos indicam que a suplementação dietética com ácidos graxos insaturados podem melhorar a qualidade e desenvolvimento do embrião (SANTOS et al., 2008; SANTOS et al., 2009). Estes estudos foram fundamentados por estudos "in vitro" Marei et al. (2009). Incorporação de ácido linolênico ao meio de maturação de oócitos aumentou a expansão do cumulus e desenvolvimento de células dos oócitos para metafase II. A maior parte dos lipídeos intracelulares em oócitos e embriões bovinos são os triacilgliceróis, correspondendo a 50\% da massa lipídica total em embriões produzidos in vivo. No entanto, essa proporção pode alcançar até $88 \%$ da massa de lipídeos em embriões produzidos in vitro (PEREIRA et al., 2008). Já os PUFAs, compreendem menos de $20 \%$ do total de ácidos graxos, sendo o CLA, da família $\omega 6$ o mais abundante deles (SANTOS et al., 2008b). Todo esse acúmulo lipídico intracitoplasmático funciona como um reservatório 
potencial de energia para o desenvolvimento embrionário inicial, antes da ativação de seu próprio genoma (KIM et al., 2001; ZERON et al., 2001; STURMEY et al., 2009).

Sabe-se que os ácidos graxos essenciais (linoleico e linolênico), CLA e outros PUFAs podem alterar a composição de lipídeos da membrana, metabolismo celular e a expressão gênica em vários tecidos, incluindo hepático, cardíaco, adipócitos e tecido nervoso (AL DARWICH et al., 2011).

Os PUFAs $\omega 3$ e $\omega 6$ tem um papel no controle da adipogênese assim como em eventos fisiológicos que reduzem a expressão gênica de diversas enzimas envolvidas no metabolismo de lipídeos.

McEvoy et al. (1995) observaram que a restrição alimentar em ovinos aumentou a quantidade de oócitos viáveis recuperados. Em vacas, a restrição alimentar prévia ao abate aumentou o desenvolvimento in vitro de embriões (MCEVOY et al., 1997). Já, em novilhas, a ingestão de dietas com alta energia diminui a qualidade dos oócitos e, consequentemente, a produção de embriões in vitro (NOLAN et al., 1998; ADAMIAK et al., 2005). 


\section{MATERIAL E MÉTODOS}

\subsection{ANIMAIS E INSTALAÇÕES}

O experimento foi conduzido nas dependências do Laboratório de Pesquisa em Bovinos de Leite do Departamento de Nutrição e Produção Animal (VNP) da Faculdade de Medicina Veterinária e Zootecnia da Universidade de São Paulo (FMVZ-USP), em Pirassununga, no período de 17 de janeiro a 30 de julho de 2014. As análises relacionadas ao metabolismo plasmático foram realizadas no Laboratório de Bioquímica e Fisiologia Animal do Departamento de Nutrição e Produção Animal (VNP) da Faculdade de Medicina Veterinária e Zootecnia da Universidade de São Paulo (FMVZ-USP), em Pirassununga.

Foram selecionadas 24 novilhas da raça Holandesa, com idade entre 12 a 18 meses de idade, pesando em média 249,8 \$19,2Kg; com atividade reprodutiva já estabelecida, divididas em três dietas experimentais em um delineamento em blocos casualizados, considerando o peso vivo incial e produção de oócitos na distribuição inicial dos animais aos blocos. A produção de oócitos foi avaliada a partir da população de oócitos através da OPU -30, ou seja, foi feita uma coleta prévia 30 dias antes do início do experimento (D 0) para classificar os animais.

Os animais foram alojados em piquetes do estilo "open lote", onde tinham ascesso à bebedouro contedo àgua ad libitum, cochos acimentados, sombrites artificiais e piso de terra batida. Semanalmente foram feitas a higienização do alojamento.

\subsection{DIETAS EXPERIMENTAIS E ANÁLISE DE ALIMENTOS}

Os animais foram distribuídos aleatoriamente de acordo com o peso vivo em blocos casualizados para receber uma das três dietas experimentais, sendo: 1) Controle (CT), composto por uma dieta basal de aproximadamente 2,5\% de extrato etéreo; 2) Grão de Soja (GS), composto por uma dieta com aproximadamente 4,5\% de extrato etéreo, baseada na inclusão de $12 \%$ de grão de soja cru e integral na MS da dieta e 3) Semente de Linhaça (SL) 
composto por uma dieta com aproximadamente 4,5\% de extrato etéreo, baseada na inclusão de 6,0\% de semente de linhaça na MS da dieta. Sendo $25 \%$ da dieta composta pelo concentrado experimental e $75 \%$ de silagem de milho, durante todo o período suplementar.

Os animais foram alimentados em grupos, uma vez ao dia, à 8:00 horas da manhã, de acordo com o consumo do dia anterior, de forma a ser mantido um porcentual de sobras das dietas, entre 5 e $10 \%$ do fornecido para não haver limitação de consumo. Posteriormente foram realizadas análises químico-bromatológicas nas amostras armazenadas de acordo com os procedimentos da AOAC (1990), realizadas no Laboratório de Bromatologia do LPBLVNP-FMVZ -USP, em Pirassununga.

Nas amostras de alimentos dos alimentos fornecidos foram determinados os teores de matéria seca (MS), matéria orgânica (MO), nitrogênio total (Kjehldal), cinzas e extrato etéreo (EE), de acordo com as metodologias descritas pela AOAC (1990). Foram avaliados também o nitrogênio insolúvel em detergente neutro (NIDN), nitrogênio insolúvel em detergente ácido (NIDA) e lignina de acordo com as metodologias descritas pela AOAC (1990). O teor de proteína bruta $(\mathrm{PB})$ foi obtido pela multiplicação do teor de nitrogênio total por 6,25. Os teores de FDN e FDA foram obtidos conforme método descrito por Van Soest et al. (1991), utilizando-se $\alpha$-amilase e sem adição de sulfito de sódio na determinação do FDN.

Os teores de carboidratos não-fibrosos foram calculados como proposto por Hall (2000) e os nutrientes digestíveis totais (NDT) foram calculados segundo Weiss (1999). Foram realizadas análises químico-bromatológicas dos ingredientes da dieta de acordo com os procedimentos da AOAC (2000) (Tabelas 1, 2 e 3). As análises químico-bromatológicas foram realizadas no Laboratório de Bromatologia do LPBL-VNP-FMVZ -USP, em Pirassununga, em seguida, foram formuladas as dietas experimentais.

Tabela 1 - Composição percentual dos concentrados experimentais

\begin{tabular}{lccc}
\hline \multirow{2}{*}{ Ingredientes (\% MS) } & \multicolumn{3}{c}{ Concentrados experimentais } \\
\cline { 2 - 4 } & $\mathrm{C}^{1}$ & $\mathrm{GS}^{2}$ & $\mathrm{SL}^{3}$ \\
\hline Milho moído & 56,87 & 44,83 & 38,61 \\
Farelo de soja & 34,01 & - & 28,21 \\
Grão de Soja & - & 46,03 & - \\
Semente de linhaça & - & - & 24,06
\end{tabular}




\begin{tabular}{|c|c|c|c|}
\hline \multirow{2}{*}{ Ingredientes (\% MS) } & \multicolumn{3}{|c|}{ Concentrados experimentais } \\
\hline & $\mathrm{C}^{\top}$ & $\mathrm{GS}^{2}$ & $\mathrm{SL}^{3}$ \\
\hline Ureia & 3,67 & 3,68 & 3,70 \\
\hline Sulfato de amônia & 0,79 & 0,84 & 0,84 \\
\hline Fosfato bicálcico & 0,79 & 0,84 & 0,84 \\
\hline Calcáreo & 1,63 & 1,64 & 1,65 \\
\hline Núcleo mineral $^{4}$ & 0,91 & 0,92 & 0,92 \\
\hline Sal comum & 1,23 & 1,24 & 1,24 \\
\hline
\end{tabular}

Tabela 2 - Composição químico-bromatológica dos ingredientes

\begin{tabular}{cccccc}
\hline & \multicolumn{5}{c}{ Ingredientes } \\
\cline { 2 - 6 } Nutrientes ${ }^{1}$ & $\begin{array}{c}\text { Farelo de } \\
\text { soja }\end{array}$ & $\begin{array}{c}\text { Milho } \\
\text { fubá }\end{array}$ & $\begin{array}{c}\text { Grão de } \\
\text { soja }\end{array}$ & $\begin{array}{c}\text { Semente de } \\
\text { linhaça }\end{array}$ & $\begin{array}{c}\text { Silagem de } \\
\text { milho }\end{array}$ \\
\hline Matéria seca (\%MN) & 83,50 & 84,45 & 85,30 & 85,70 & 35,51 \\
Matéria orgânica (\%MS) & 93,12 & 91,12 & 94,72 & 95,78 & 94,74 \\
Proteína bruta (\%MS) & 49,97 & 8,98 & 38,03 & 22,21 & 6,60 \\
NIDN (\%NT) & 6,02 & 8,65 & 12,78 & 15,16 & 17,89 \\
NIDA (\%NT) & 2,26 & 3,63 & 6,04 & 7,22 & 11,34 \\
Extrato etéreo (\%MS) & 2,79 & 3,19 & 24,18 & 34,51 & 2,90 \\
CNF (\%MS) & 29,17 & 69,58 & 10,61 & 20,34 & 29,73 \\
FDN (\%MS) & 11,19 & 10,37 & 21,90 & 18,72 & 55,51 \\
FDA (\%MS) & 6,78 & 3,40 & 7,44 & 7,16 & 25,95 \\
Lignina (\%MS) & 2,22 & 2,14 & 3,06 & 3,89 & 5,56 \\
Cinzas( \%MS) & 6,88 & 8,88 & 5,28 & 4,22 & 5,26 \\
NDT & 79,85 & 86,34 & 115,49 & 129,27 & 64,14 \\
EL(Mcal/kg MS) & 2,31 & 2,20 & 2,74 & 3,33 & 1,87 \\
\hline${ }^{2}$ MN = matéria natural; MS= matéria seca; NT= nitrogênio total; ${ }^{2}$ Estimado pelas equações do NRC (2001).
\end{tabular}

Tabela 3 - Composição percentual das dietas experimentais

\begin{tabular}{lccc}
\hline \multicolumn{1}{c}{ Ingredientes (\% MS) } & \multicolumn{3}{c}{ Dietas experimentais } \\
\cline { 2 - 4 } & $\mathrm{C}^{1}$ & $\mathrm{GS}^{2}$ & $\mathrm{SL}^{3}$ \\
\hline Silagem de milho & 74,99 & 75,05 & 75,16 \\
Milho moído & 14,23 & 11,18 & 9,58 \\
Grão de soja & - & 11,48 & - \\
Farelo de soja & 8,51 & - & 7,00 \\
Semente de linhaça & - & - & 5,97 \\
Ureia & 0,92 & 0,92 & 0,92 \\
Sulfato de amônia & 0,20 & 0,21 & 0,21
\end{tabular}




\begin{tabular}{lccc}
\hline \multirow{2}{*}{ Ingredientes (\% MS) } & \multicolumn{3}{c}{ Dietas experimentais } \\
\cline { 2 - 4 } & $\mathrm{C}^{1}$ & $\mathrm{GS}^{2}$ & $\mathrm{SL}^{3}$ \\
\hline Fosfato bicálcico & 0,20 & 0,21 & 0,21 \\
Calcário & 0,41 & 0,41 & 0,41 \\
Núcleo mineral $^{4}$ & 0,23 & 0,23 & 0,23 \\
Sal comum & 0,31 & 0,31 & 0,31 \\
${ }^{1}$ Controle; ${ }^{2}$ Grã de Soja cru e integral; ${ }^{3}$ Semente de Linhaça; ${ }^{4}$ Composição por kg do produto: Vit, A- \\
8000UI; vit E - 50000mg; vit D - 2300UI. ${ }^{4}$ Composição por kg do produto: Mg-10g; S-9g;; Zn- \\
23,750mg; Cu-5625mg; Mn-18125mg; Fe-5,000mg; Co-125mg; I-312mg; Se-144mg; F (máx,) 900mg; \\
vit, A- 2000UI; vit E - 12500mg; vit D - 5000UI.
\end{tabular}

Tabela 4 - Composição químico-bromatológica das dietas experimentais

\begin{tabular}{lccc}
\hline \multirow{2}{*}{\multicolumn{1}{c}{ Nutrientes }} & \multicolumn{3}{c}{ Dietas Experimentais } \\
\cline { 2 - 4 } & $\mathrm{C}^{1}$ & $\mathrm{GS}^{2}$ & $\mathrm{SL}^{3}$ \\
\hline Matéria seca $\left(\% \mathrm{MN}^{4}\right)$ & 41.56 & 41.59 & 41.53 \\
Proteína bruta $\left(\% \mathrm{MS}^{5}\right)$ & 13.16 & 13.00 & 13.33 \\
Extrato etéreo (\%MS) & 2.87 & 5.31 & 4.74 \\
Carboidrato não fibroso (\%MS) & 34.68 & 31.31 & 32.27 \\
Fibra em detergente neutro (\%MS) & 44.05 & 45.33 & 44.62 \\
Fibra em detergente ácido (\%MS) & 20.52 & 20.71 & 20.73 \\
Lignina (\%MS) & 4.66 & 4.76 & 4.77 \\
Matéria mineral (\%MS) $_{\text {NDT }^{6}}$ & 7.01 & 6.78 & 6.77 \\
\hline
\end{tabular}

${ }^{1}$ Controle; ${ }^{2}$ Grã de Soja cru e integral; ${ }^{3}$ Semente de Linhaça; $\mathrm{MN}^{4}$ - Matéria Natural; MS ${ }^{5}$ - Matéria Seca; $\mathrm{NDT}^{6}$ - Nutrientes Digestíveis Totais

\subsection{AVALIAÇÃO DE PESO CORPORAL E GANHO DE PESO DIÁRIO}

Os animais foram pesados mensalmente, logo após sincronização hormonal, por volta das 8 horas da manhã. Para as pesagens, os animais eram conduzidos à balança, anteriormente ao fornecimento do trato, e não foi restringida alimentação, ou seja, eles não permaneciam em jejum. Foram avaliadas as mudanças de peso durante o período entre as coletas (OPU), em todo período experimental.

\subsection{COLETA DE SANGUE E FLUÍDO FOLICULAR PARA ANÁlise METABÓLICA}


Durante o período experimental foram realizadas coletas de sangue e do fluído folicular do folículo dominante para avaliação metabólica. As coletas foram realizadas 6 dias após as aspirações foliculares (OPUs), 6, 36, 66, 96 e 126, respectivamente. As amostras de sangue foram colhidas em 3 tubos de vácuo de $10 \mathrm{ml}$ (Vacutainer ${ }^{\circledR}$, Becton-Dickinson e Company, EUA), sendo um com fluoreto de sódio e dois sem anticoagulante. Os soros foram obtidos por centrifugação $\left(3000 \mathrm{rpm}\right.$, por 10 min., em centrífuga excelsa Baby ${ }^{\circledR}$, Fanem, Brasil). Os soros separados foram acondicionados em tubos esterilizados (tubos Eppendorf 3810x Standard ${ }^{\circledR}$, Eppendorf, Alemanha) com identificação e em seguida, armazenados em freezer a $-20^{\circ} \mathrm{c}$ até posterior análise dos parâmetros metabólicos como glicose, colesterol total, colesterol HDL, colesterol LDL e colesterol V-LDL, triglicerídeos, proteínas totais e ureia.

A amostra de líquido folicular foi obtida por aspiração do folículo dominante, 11 dias após o início da sincronização (ou 6 dias após a OPU) e armazenadas em tubos Eppendorfs com identificação e em seguida, armazenados em freezer a $-20^{\circ} \mathrm{c}$ até posterior análise. $\mathrm{Na}$ avaliação metabólica folicular foram analisadas as concentrações de glicose, colesterol total, triglicerídeos e ureia.

A determinação dos teores de glicose plasmática e do fluido folicular das amostras foi realizada por método enzimático colorimétrico, utilizando o kit Cat 02200 (Laborlab $^{\circledR}$, Guarulhos, Brasil), adaptado para leitura em tubos no aparelho do tipo espectrofotômetro com comprimento de luz de $500 \mathrm{~nm}$. No método proposto por Trinder (1969), a glicose é oxidada a peróxido de hidrogênio e a reação deste com 4-aminoantipirina e fenol formam a quinoneimina, um composto de cor rosa.

O teor de colesterol sérico e do fluído folicular foi quantificado por metodologia enzimática colorimétrica, em analisador bioquímico modelo AMS (Liasys ${ }^{\circledR}$, Itália) utilizandose kit comercial (Biosystems ${ }^{\circledR}$, Espanha). Nesse método, o colesterol é exposto à ação das enzimas colesterol esterase e posteriormente à colesterol oxidase, formando um subproduto e água oxigenada. A água oxigenada formada reage com a 4-amino antipirina e fenol, que na presença de peroxidase, forma um composto colorido cuja intensidade, em espectrofotômetro com comprimento de luz de 500nm, é diretamente proporcional à concentração de colesterol presente na amostra (ALLAIN et al., 1974).

A concentração de C-HDL no soro foi determinada em duas etapas, sendo a primeira envolvendo preparação prévia das amostras, e a segunda a análise propriamente dita. Para a realização da análise da concentração de C-HDL, $250 \mu 1$ da amostra foram pipetados em tubos Ependorff de 2,5 ml, juntamente com $250 \mu \mathrm{l}$ do reativo único precipitante $\left(\mathrm{CELM}^{\circledR}{ }^{-1763}\right)$ na 
proporção de 2:1 e misturados manualmente por inversão suave durante 20 segundos. Em seguida as amostras foram deixadas em repouso e resfriadas por 10 minutos. Posteriormente, as amostras preparadas foram centrifugadas durante 15 minutos a $3500 \mathrm{x}$ g. Nos volumes centrifugados restaram as moléculas de C-HDL ligadas ao colesterol sendo estas analisadas por sistema bioquímico automático (SBA-200). No volume centrifugado as lipoproteínas LDL e VLDL foram precipitadas seletivamente pelo ácido fosfotugstico. No sobrenadante, separado pela centrifugação restaram as moléculas de HDL ligadas ao colesterol.

A concentração de ureia sérica e do líquido folicular foi determinada por método enzimático colorimétrico, descrito por Henry; Cannon; Winkelman (1974), utilizando o kit Cat 02800 (Laborlab $^{\circledR}$, Guarulhos, Brasil) adaptado para leitura em tubos no aparelho do tipo espectrofotômetro com comprimento de luz de 620 nanômetros. 


\subsection{ULTRASSONOGRAFIA OVARIANA E ASPECTOS REPRODUTIVOS}

A atividade ovariana foi avaliada em todos os animais do experimento, sendo utilizado um aparelho de ultrassom portátil contendo as modalidades B-mode (escala de cinza) (MyLabTM30, Esaote, Genova, Itália), acoplado a um transdutor linear multi-frequencial pertencente ao Departamento de Reprodução Animal, FMVZ-USP, Campus de Pirassununga. A ultrassonografia foi realizada via transretal, mensalmente, durante todo período de coleta, a fim de realizar o mapeamento dos ovários direito e esquerdo para posterior coleta oócitária.

\subsection{PROTOCOLO DE SINCRONIZAÇÃO PARA OPU}

As aspirações foliculares foram precedidas de sincronização da emergência de onda de crescimento folicular. Para isso administrou-se $2 \mathrm{mg}$ de Benzoato de estradiol (BE) e um implante auricular de Norgestomet (Crestar ${ }^{\circledR}$, Intervet Schering-PloughAnimal Health). Cinco dias após a administração dos tratamentos hormonais, foi realizada a OPU. Os animais permaneceram com o implante auricular por mais 6 dias para realização da colheita do fluído folicular do folículo dominante (Figura 1). 
Figura 1 - Protocolo de sincronização hormonal utilizado nas novilhas dos grupos experimentais

\section{1) Grupo $\mathrm{CT} \quad(\mathrm{n}=8)$}

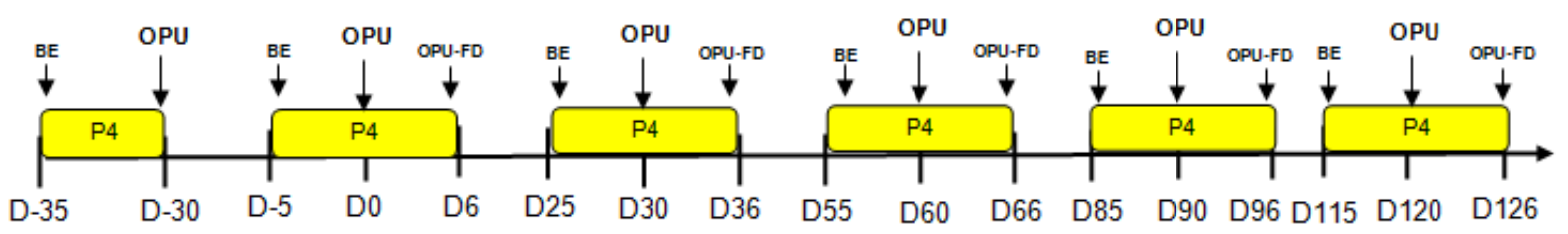

2) Grupo GS $(n=8)$

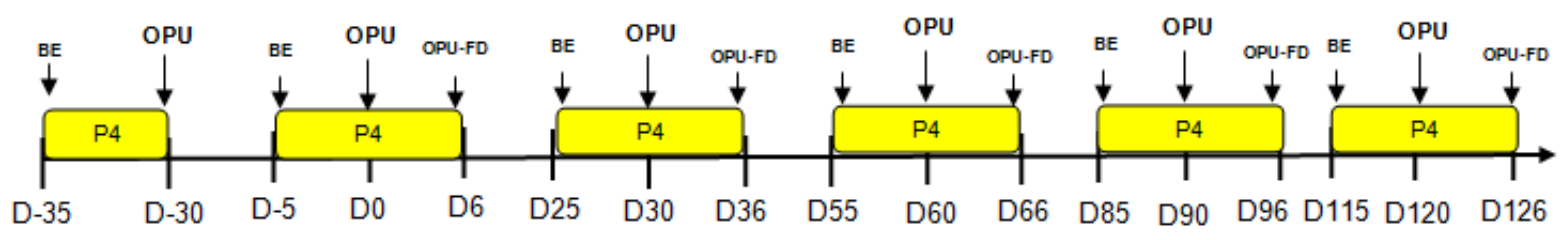

3) Grupo SL (n= 8)

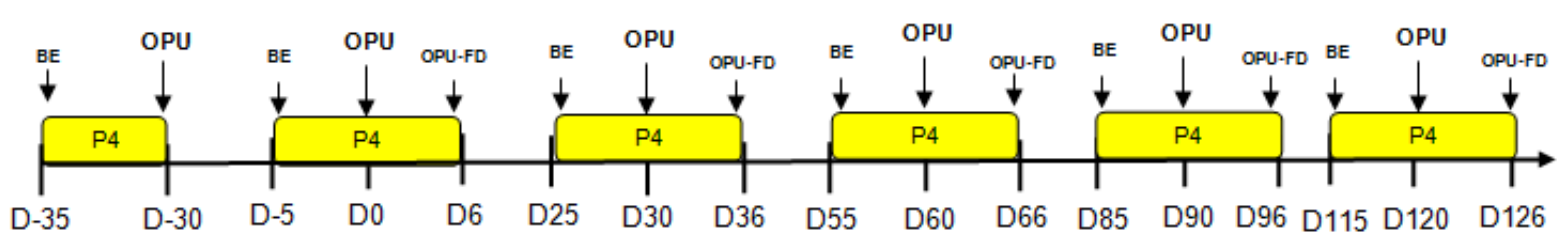

Fonte: VERDURICO, 2013.

5.7ASPIRAÇÃO FOLICULAR (OPU)

\subsubsection{Preparação do equipamento e dos animais}

As sessões de OPU foram realizadas com aparelho portátil de ultrassom MyLabTM30, (Esaote, Genova, Itália) equipado com transdutor endocavitário micro-convexo mulifrequencial, adaptado a uma guia de biopsia WTA Ltda (Cravinhos/SP, Brasil) para aspiração folicular e conectado a agulha V-OPAA-1855 (Cook Austrália, Queensland, Austrália) descartável de 18G e linha de aspiração VBOAS 18L (Cook Austrália, Queensland, 
Austrália) de teflon de $1,7 \mathrm{~mm}$ de diâmetro interno e $80 \mathrm{~cm}$ de comprimento, conectadas a um recipiente para coleta dos oócitos (tubos cônicos de centrífuga de $50 \mathrm{~mL}$ da Corning Life Science Incorporated - Massachusetts/EUA). Este sistema de aspiração foi acoplado a bomba de vácuo portátil V-MAR 5000 (Cook Austrália, Queensland, Austrália), calibrada e regulada com pressão negativa de 68mmHg (12 à $15 \mathrm{~mL}$ de água/minuto; KRUP et al., 1994).

A montagem do transdutor foi feita segundo instruções do fabricante e a agulha inserida no mandril de forma asséptica para evitar contaminação. Na montagem dos equipamentos envolvidos na OPU, foi mantida rigorosa assepsia, principalmente com as partes que entravam em contato direto com o material aspirado ou com as mucosas das doadoras.

O meio de aspiração utilizado para lubrificação e lavagem do sistema de OPU e para o recebimento dos oócitos no tubo de coleta foi preparado com 1,0 L de solução salina fosfatada (DPBS - Dmpbs Flush, Nutricell, São Paulo, Brasil), acrescido de 5000 UI de heparina sódica $\left(5,0 \mathrm{UI} / \mathrm{mL}\right.$, Liquemine ${ }^{\circledR}$, Roche Brasil, São Paulo, Brasil) e 10,0 mL de soro fetal bovino (SFB - Nutricell, São Paulo, Brasil), mantidos a aproximadamente $37^{\circ} \mathrm{C}$.

Após a contenção física do animal em brete apropriado, foi realizada lentamente anestesia epidural baixa entre a última vértebra coccígena e a primeira vértebra caudal, com 2,0 a 3,0 mL de cloridrato de lidocaína $2 \%$ (Lidovet $^{\circledR}$ Bravet, RJ/Brasil), sem vasoconstritor (KRUIP et al., 1994).

Após a perda dos reflexos caudais, a cauda da novilha foi amarrada e se procedeu a remoção manual de fezes da ampola retal e higienização mecânica da região perineal, com água. A vulva e o vestíbulo vaginal também foram cuidadosamente higienizados, tomando-se o cuidado de não jogar água dentro da vagina.

\subsubsection{Aspiração folicular}

Como já descrito, procedimento de OPU foi realizado em seis diferentes tempos, -30, 0, 30, 60, 90 e 120 dias, sendo que o -30 foi realizada OPU para seleção dos grupos experimentais a partir da produção oocitária, os demais tempos $(0,30,60,90$ e 120) foram realizados a partir do início do fornecimento das dietas experimentais. As variáveis mensuradas na OPU foram número total de oócitos aspirados, oócitos de grau I, II e III, número de oócitos viáveis, degenerados e atrésicos. Na avaliação da qualidade embrionária foram avaliados o número e a porcentagem de embriões clivados e viáveis, sendo que todos 
os embriões viáveis foram submetidos ao cultivo, maturação, fertilização in vitro. As aspirações foliculares foram realizadas pela empresa IN VITRO (Rod. SP 340 - KM 166, Mogi Mirim - SP), realizadas por médicos veterinário experientes, treinados e aptos, que realizavam este tipo de procedimento de aspiração com frequência diária.

As sessões de OPU foram realizadas com aparelho portátil de ultrassom, equipado com transdutor endocavitário micro-convexo mulifrequencial, adaptado a uma guia de biopsia WTA Ltda (Cravinhos/SP, Brasil) para aspiração folicular e conectado a agulha V-OPAA1855 (Cook Austrália, Queensland, Austrália) descartável de 18g e linha de aspiração VBOAS 181 (Cook Austrália, Queensland, Austrália) de teflon de 1,7 mm de diâmetro interno e $80 \mathrm{~cm}$ de comprimento, conectadas a um recipiente para coleta dos oócitos (tubos cônicos de centrífuga de $50 \mathrm{ml}$ da Corning Life Science Incorporated - Massachusetts/EUA). Este sistema de aspiração foi acoplado na bomba de vácuo portátil V-MAR 5000 (Cook Austrália, Queensland, Austrália), calibrada e regulada com pressão negativa de 68 MMHG (12 a 15 ml de água/minuto; KRUP et al., 1994).

A montagem do transdutor foi feita segundo instruções do fabricante e a agulha inserida no mandril de forma asséptica para evitar contaminação. Na montagem dos equipamentos envolvidos na OPU, foi mantida rigorosa assepsia, principalmente com as partes que entravam em contato direto com o material aspirado ou com as mucosas das doadoras.

O meio de aspiração utilizado para lubrificação e lavagem do sistema de OPU e para o recebimento dos oócitos no tubo de coleta foi preparado com 1,0 1 de solução salina fosfatada (DPBS - Dmpbs Flush, Nutricell, SP/Brasil), acrescido de 5000 UI de heparina sódica (5,0 ui/ml, Liquemine ${ }^{\circledR}$, Roche Brasil, SP/Brasil) e 10,0 ml de soro fetal bovino (SFB Nutricell, SP/Brasil), mantidos a aproximadamente $37^{\circ} \mathrm{C}$.

Após a contenção física do animal em brete apropriado, foi realizada lentamente anestesia epidural baixa entre a última vértebra coccígena e a primeira vértebra caudal, com 2,0 a 3,0 ml de cloridrato de lidocaína $2 \%$ (Lidovet ${ }^{\circledR}$ Bravet, RJ/Brasil), sem vasoconstritor (KRUIP et al., 1994). Esta dosagem irá variar de acordo com o tamanho, raça, idade, sensibilidade individual e estado geral de cada animal.

Após a perda dos reflexos caudais, a cauda da novilha foi amarrada e se procederá a remoção manual de fezes da ampola retal e higienização mecânica da região perineal, com água. A vulva e o vestíbulo vaginal também foram cuidadosamente higienizados, tomando-se o cuidado de não jogar água dentro da vagina. 
Após anestesia e higienização da doadora, o braço esquerdo do operador foi mantido posicionado no reto do animal evitando assim a entrada de ar na ampola retal, o que dificulta a realização da OPU. Visando a padronização da técnica e devido à dificuldade de acesso, o ovário esquerdo foi o primeiro a ser aspirado. O ovário foi palpado, inspecionado e isolado de outros tecidos (vasos sanguíneos, porções intestinais, tecido adiposo) para evitar sua perfuração acidental e, em seguida, o transdutor, acoplado a guia de biopsia e agulha, foi introduzido na vagina até alcançar o fundo de saco vaginal no lado correspondente ao ovário que foi acessado. Por meio de manipulação transretal, o ovário foi apresentado ao transdutor na face abdominal da parede da vagina, de forma que os folículos a serem aspirados fiquem no percurso da agulha, indicado na tela do ultrassom pela linha de biópsia ou linha de punção (punction line).

Antes do início da OPU, foi feito um mapeamento do ovário a fim de se planejar a aspiração, evitando perfurações desnecessárias, otimizando o procedimento e preservando os ovários da doadora. Seguir-se-á a aspiração transpassando-se a agulha através da parede do fundo de saco vaginal ao mesmo tempo em que foi acionada a pressão negativa de vácuo por um pedal e os folículos foram aspirados (NIBART et al., 1995). Desta forma, foram aspirados todos os folículos visíveis (com diâmetro $\geq 1,0 \mathrm{~mm}$ ) e acessíveis de cada ovário.

Ao término da OPU de cada animal o tubo contendo o líquido aspirado foi trocado, identificado e enviado para o técnico do laboratório-campo, para lavagem do conteúdo, procura, seleção e envase dos oócitos aspirados.

O tubo com o conteúdo aspirado foi despejado em filtro de coleta de embriões WTA (Watanabe Tecnologia Aplicada Ltda, Cravinhos, SP/Brasil). O conteúdo contendo o fluido aspirado presente no filtro de coleta de embriões foi lavado até se obter um líquido translúcido com cerca de $1.0 \mathrm{~cm}$ de altura e com um sedimento contendo os oócitos recuperados. Este conteúdo foi vertido em placas de petri para observação em esteriomicroscópio (Neovet Ind. e Com. e Serviços Ltda, Uberaba, MG/Brasil) e realização da procura, lavagem, classificação e seleção do complexo cumulus oocitário (CCO).

Os critérios considerados para a avaliação dos CCO foram a presença, o número de camadas e o grau de expansão das células do cumulus, bem como o aspecto do citoplasma quanto à cor, homogeneidade e integridade. Desta maneira, os oócitos recuperados foram classificados de acordo com sua morfologia, mensurando-se a quantidade de camadas e compactação das células do cumulus e a homogeneidade do ooplasma, em sete categorias, semelhante ao descrito por Lonergan et al. (1992). 
Foram considerados como viáveis e, consequentemente, aproveitados para FIV somente os oócitos classificados como graus I, II e III, enquanto os demais, que não apresentarem aspecto de granulações citoplasmáticas homogêneo, foram descartados. No entanto, foram somados àqueles para compor o número total de oócitos.

Após a classificação, os oócitos foram lavados em solução de TCM199 GIBCO ${ }^{\circledR}$ Invitrogen Corporatio, Califórnia/EUA, suplementada com 10\% de SFB. Em seguida, foi efetuada a contagem por categoria e o envase dos oócitos para transporte em Criotubos (Corning Life Science Incorporated, Massachusetts/EUA) com a mesma solução de lavagem, acrescido de HEPES Nutricell (Campinas, SP/Brasil), em banho-maria a $37^{\circ} \mathrm{C}$. O tempo médio de transporte foi de 1,5 horas, totalizando média de 5,0 horas desde o início da aspiração da primeira novilha até a chegada dos oócitos viáveis ao laboratório de FIV.

\subsubsection{Produção in vitro de embriões (PIVE)}

A fase de produção in vitro foi totalmente executada em laboratório pertencente à Empresa IN VITRO de PIVE, onde os oócitos aspirados foram submetidos à maturação, fecundação e cultivo in vitro, num período total de oito dias.

Após transporte controlado, os oócitos foram transferidos para as placas de MIV, agrupados e maturados em microgotas de $100 \mu \mathrm{l}$ de meio de maturação tcm199 suplementado com $10 \%$ de SFB, piruvato $(22 \mu \mathrm{g} / \mathrm{ml})$, gentamicina, $(50 \mu \mathrm{g} / \mathrm{ml}), 5,0 \mu \mathrm{g} / \mathrm{ml}$ de FSH FOLTROPIN $^{\circledR}$ (Bioniche Animal Health, Belleville, Ontário, Canadá), 50,0 $\mu \mathrm{g} / \mathrm{ml}$ de LH PROFASI $^{\circledR}$ (Serono, SP/Brasil) e $1 \mu \mathrm{g}$ de estradiol/ml, sendo cada microgota referente a um animal.

As microgotas de MIV foram cobertas com óleo mineral sigma (Aldrich, São Paulo, $\mathrm{SP} /$ Brasil) e os oócitos permaneceram incubados durante 22 a 24 horas a $38,5^{\circ} \mathrm{C}$, em atmosfera de $5 \%$ de $\mathrm{CO}_{2}$ em ar e com máxima umidade (WATANABE et al., 1998a,b).

Uma vez maturados, os oócitos foram submetidos à FIV, em microgotas de $100 \mu \mathrm{g}$ de meio talp suplementado com heparina $(10 \mu \mathrm{g} / \mathrm{ml})$, piruvato $(22 \mu \mathrm{g} / \mathrm{ml})$, gentamicina (50 $\mu \mathrm{g} / \mathrm{ml})$, albumina sérica bovina (6 mg/ml), solução de PHE ( $2 \mu \mathrm{m}$ de penicilamina, $1 \mu \mathrm{m}$ de hipotaurina e 0,25 $\mu \mathrm{m}$ de epinefrina) e recobertas com óleo mineral. O sêmen utilizado em todo o experimento foi do mesmo reprodutor (raça Holandesa) e mesma partida. As palhetas contendo o sêmen diluído foram descongeladas em banho-maria a $35^{\circ} \mathrm{C}$ durante 30 segundos 
e o seu conteúdo foi centrifugado por meio da técnica de gradiente de percoll (45 e 90\%) para obtenção dos espermatozoides móveis e remoção do diluidor e do plasma seminal. A concentração foi ajustada para $2,0 \times 10^{6}$ espermatozoides $/ \mathrm{ml}$ e os gametas permaneceram incubados nas microgotas, durante um período de 18 a 20 horas a $38,5^{\circ} \mathrm{C}$, em atmosfera de $5 \%$ de $\mathrm{CO}_{2}$ em ar.

Após os procedimentos de MIV e FIV, os possíveis zigotos foram lavados e transferidos para microgotas com $50 \mu \mathrm{l}$ de meio $\mathrm{Cr}_{2}$ modificado e suplementado com $10 \%$ SFB, 30 mg BSA/ml, acrescido de aminoácidos essenciais e não essenciais (WATANABE et al., 1999), onde permaneceram em desenvolvimento embrionário por sete dias, em incubadora a $38,5^{\circ} \mathrm{c}$, com $5 \%$ de $\mathrm{co}_{2} \mathrm{em}$ ar e umidade máxima, até atingirem os estágios de mórula (MO) e blastocisto (BL). Decorridas 48 horas de CIV, foi avaliada a taxa de clivagem e, em seguida os embriões viáveis foram congelados.

\subsubsection{Cultivo in vitro (CIV)}

Decorridas 48 horas de CIV, foi avaliada a taxa de clivagem e, em seguida, foi feito o feeding (renovação de $40 \mu \mathrm{L}$ de meio de CIV). No dia 6 do cultivo (D6), foi realizado o segundo feeding, classificação e contagem dos blastocistos. No D7, foi realizada a classificação e a contagem de blastocistos totais obtidos. Após essa etapa, os blastocistos foram congelados para posterior coloração e contagem do número de células presentes. 


\section{ANÁLISES ESTATÍSTICAS}

Foi utilizado um delineamento em blocos casualizados, com os animais distribuídos aos blocos de acordo com o peso vivo corporal de modo a obter três grupos de animais homogêneos entre si. Dentro de cada bloco os animais foram distribuídos aleatoriamente às dietas experimentais (controle, grão de soja e semente de linhaça). As variáveis foram avaliadas por meio do procedimento PROC MIXED do SAS versão 9.2, com medidas repetidas no tempo. Foi utilizado a metodologia de Arcaike para tal análises, uma vez que esse procedimento permite melhor ajuste na estrutura da matriz que descreve as covariâncias de medidas repetidas no tempo. Na avaliação dessas variáveis foram considerados os efeitos fixos de tratamento (dietas experimentais), período (dias) e interação tratamento x período, além do efeito fixo de bloco, utilizando o seguinte modelo:

$$
Y_{i j k}=\mu+D_{i}+B_{j}+T_{k}+D_{i} * T_{k}+e_{i j k}
$$

Onde: $\mu=$ média avaliada, $\mathrm{D}_{\mathrm{i}}=$ efeito fixo de dieta; $B_{j}=$ efeito fixo de bloco; $T_{k}=$ efeito fixo de tempo; $D_{i} * T_{k}=$ interação entre tempo e dieta; $e_{i j k}=$ erro experimental. $\mathrm{O}$ efeito de dieta foi estudado com os seguintes contrastes ortogonais (Controle vs Fontes de Gordura; Grão de Soja vs Semente de Linhaça), utilizando um nível de 5\% de significância.

Todas as análises estatísticas passaram pela análise de homogeneidade das variâncias e normalidade dos resíduos (teste de Shapiro-Wilk), caso houve necessidade foram utilizadas exclusão de out-liers e transformação de dados. 


\section{RESULTADOS E DISCUSSÃO}

\subsection{PESO CORPORAL E GANHO MÉDIO DE PESO}

Tabela 5 - Ganho de peso diário (GPD), peso corporal de novilhas alimentadas com dietas contendo fontes lipídicas suplementares

\begin{tabular}{ccccccccccc}
\hline \multirow{2}{*}{ Item } & \multicolumn{3}{c}{ Dietas $^{1}$} & \multirow{2}{*}{ Média } & \multirow{2}{*}{ EPM $^{2}$} & \multicolumn{4}{c}{ Probabilidades $(P)^{3}$} \\
\cline { 2 - 8 } & CT & GS & SL & & & Dieta & Tempo & I D*T $^{4}$ & C1 & C2 \\
\hline GPD (g/d) & 1072 & 960 & 842 & 959 & 43,1 & 0,063 & 0,088 & 0,863 & 0,040 & 0,210 \\
Peso (kg) & 341,8 & 331,4 & 325,3 & 333 & 4,8 & 0,229 & $<0,001$ & 0,163 & 0,153 & 0,564 \\
\hline
\end{tabular}

${ }^{1}$ Dietas: CT: Controle; GS: Grão de Soja; SL: Semente de Linhaça; ${ }^{2}$ EPM: Erro padrão da média; ${ }^{3}$ Probabilidade: tempo;

${ }^{4}$ Interação dieta*tempo (I D*T); C1 (contraste 1: CT vs fontes lipídicas; C2 (contraste 2: GS vs SL)

O peso vivo das novilhas é um elemento que afeta a sequência de eventos que desencadeiam a puberdade (PATTERSON et al., 1992). É sabido que novilhas de corte podem atingir a puberdade com cerca de $60 \%$ a $85 \%$ do peso adulto (ARIJE; WILTBANK, 1971; MONTANHOLI et al., 2004; FRENEAU et al., 2008). Variações são justificadas pelo manejo alimentar e variação genética de cada rebanho.

Sendo assim a análise do desenvolvimento de novilhas é uma maneira de mostrar a importância do peso e da seleção de animais de maior crescimento no início do acasalamento para que sejam alcançados índices de gestação que aumentam a produtividade, melhorando a eficiência do sistema (BARCELLOS et al., 2006).

Os animais alimentados com a dieta controle tiveram maior $(\mathrm{P}<0,05)$ ganho de peso que os animais que receberam as dietas com adição lipídica. Enquanto os animais alimentados com a dieta controle apresentaram ganho de peso médio de 1072g/dia, os animais alimentados com as dietas contendo fontes lipídicas apresentaram ganho médio de 901g/dia, independentemente do tempo de avaliação. Não houve $(\mathrm{P}>0,05)$ interação entre dieta e tempo de suplementação para o ganho de peso e as dietas contendo lipídios não diferiram $(\mathrm{P}>0,05)$ entre si (Figura 2).

Independentemente do tempo de avaliação, as dietas experimentais não levaram a diferenças significativas no peso vivo dos animais, embora houveram diferenças no GPD $(\mathrm{P}<0,05)$, esta mudança não refletiu em diferenças no peso corporal dos animais ao final do período de avaliação do estudo. Como o peso vivo foi balanceado no início do estudo e a variação desta variável é bem maior que o ganho de peso, era de se esperar diferenças nesta 
variável. Como o ganho de peso dos animais, independentemente dos tratamentos, foi positivo o peso vivo aumentou $(\mathrm{P}<0,05)$ com o passar do tempo (Figura 3 ), o que pode ser atribuído à menos deposição de gordura desses animais em relação a taxa de crescimento ósseo e muscular.

De acordo com Santos et al. (2002) o ganho médio diário do nascimento aos 15 meses de idade de novilhas da raça Holandesa no período de recria deve ser de 0,700 kg, para que as novilhas alcancem, aos 15 meses de idade, o peso ideal para a concepção e, aos 24 meses de idade, tenham o seu primeiro parto.

Figura 2 - Ganho de peso diário (GPD) de novilhas alimentadas com grão de soja (GS) e semente de linhaça (SL) durante 120 dias de suplementação

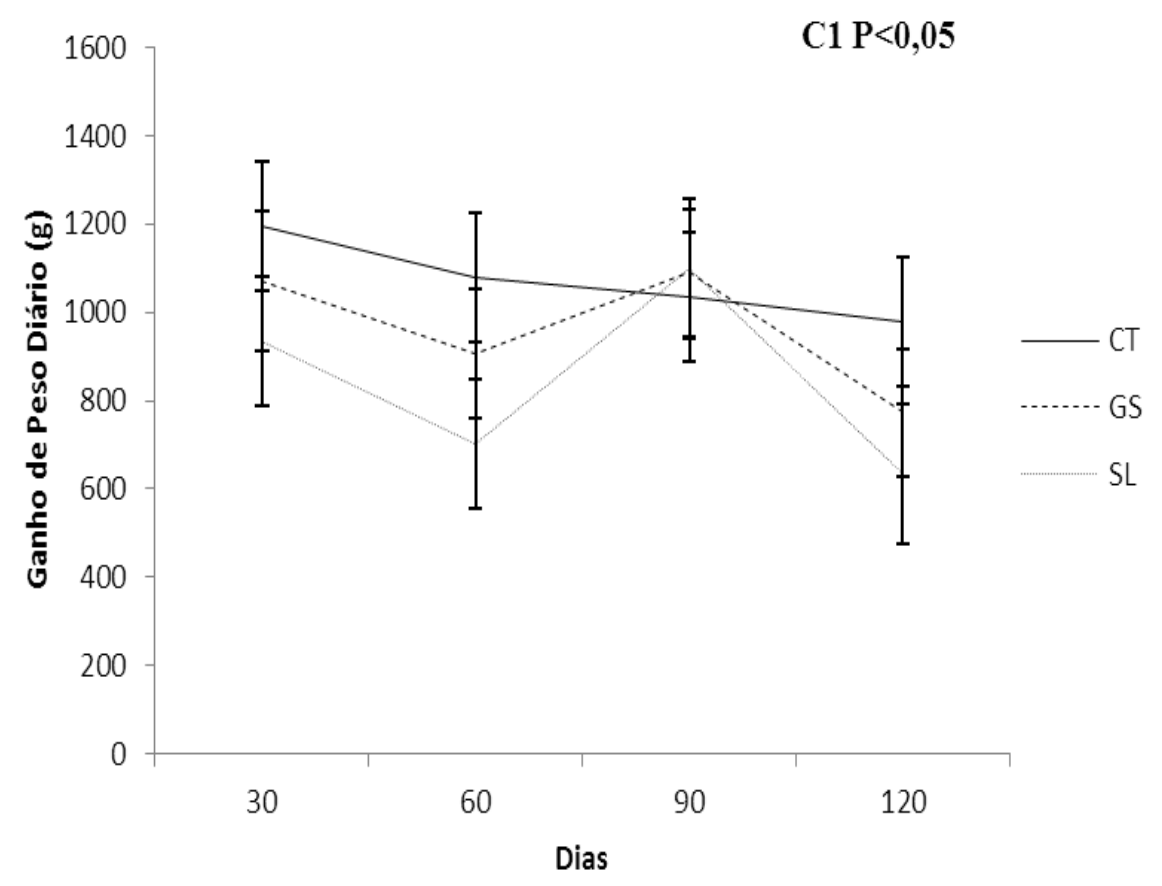


Figura 3 - Peso corporal de novilhas alimentadas com grão de soja (GS) e semente de linhaça (SL) durante 120 dias de suplementação

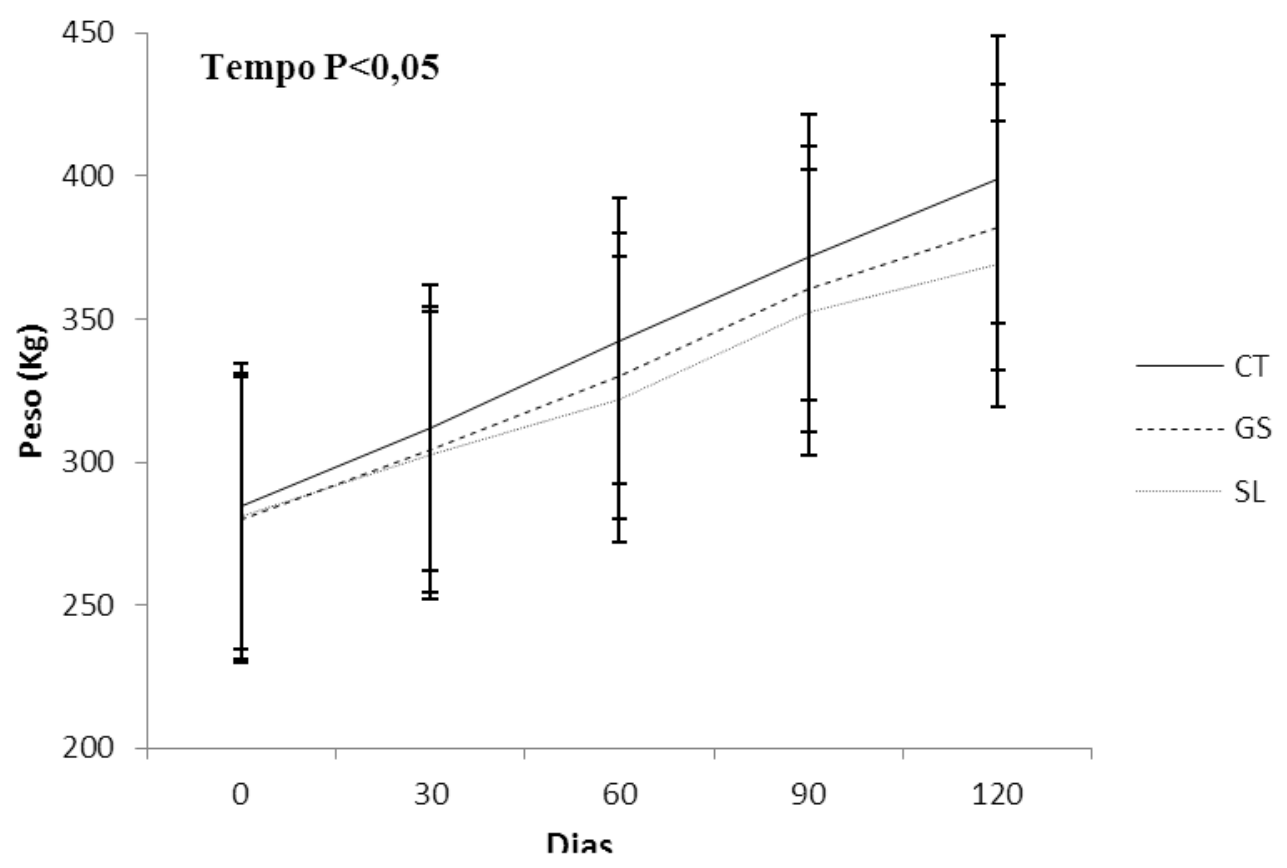

\subsection{PARÂMETROS SANGUÍNEOS}

\subsubsection{Perfil metabólico}

A avaliação do status nutricional de um rebanho pode ser realizada mediante a determinação de alguns metabólitos sanguíneos. A utilização do perfil metabólico em animais de produção atua como um método auxiliar na avaliação de rebanhos com diferentes índices produtivos e reprodutivos, atuando também como uma importante ferramenta no diagnóstico clínico de doenças metabólicas.

Houve efeito de tempo $(\mathrm{P}<0,05)$ para todas as variáveis analisadas ao longo de todo período experimental (Tabela 6). 
Tabela 6 - Parâmetros sanguíneos de novilhas alimentadas com dietas contendo fontes lipídicas suplementares

\begin{tabular}{|c|c|c|c|c|c|c|c|c|c|c|}
\hline \multirow{2}{*}{ Item } & \multicolumn{3}{|c|}{$\operatorname{Dietas}^{1}$} & \multirow{2}{*}{ Média } & \multirow{2}{*}{$\mathrm{EPM}^{2}$} & \multicolumn{5}{|c|}{ Probabilidades $(P)^{3}$} \\
\hline & $\mathrm{CT}$ & GS & SL & & & Dieta & Tempo & $\mathrm{I} \mathrm{D}^{*} \mathrm{~T}^{4}$ & $\mathrm{C} 1$ & $\mathrm{C} 2$ \\
\hline Glicose & 152,29 & 141,74 & 144,78 & 146,27 & 1,52 & 0,089 & $<0,001$ & 0,047 & 0,036 & 0,514 \\
\hline Colesterol Total & 75,35 & 87,73 & 91,05 & 84,71 & 2,53 & 0,155 & $<0,001$ & 0,761 & 0,062 & 0,684 \\
\hline Triglicerídeos & 29,31 & 25,33 & 26,88 & 27,20 & 0,95 & 0,366 & 0,003 & 0,765 & 0,196 & 0,580 \\
\hline Colesterol-VLDL & 5,86 & 5,07 & 5,38 & 5,44 & 0,19 & 0,366 & 0,003 & 0,765 & 0,196 & 0,580 \\
\hline Colesterol-HDL & 54,10 & 59,60 & 61,00 & 58,23 & 1,47 & 0,417 & $<0,001$ & 0,182 & 0,201 & 0,798 \\
\hline Colesterol-LDL & 18,17 & 24,27 & 25,37 & 23,72 & 1,25 & 0,166 & 0,006 & 0,658 & 0,065 & 0,775 \\
\hline Ureia & 20,01 & 20,71 & 18,29 & 19,76 & 0,58 & 0,498 & $<0,001$ & 0,002 & 0,781 & 0,259 \\
\hline Proteína Total & 7,52 & 7,11 & 7,42 & 7,35 & 0,06 & 0,198 & $<0,001$ & 0,761 & 0,202 & 0,196 \\
\hline
\end{tabular}

Apesar de apresentar um efeito dependente $(\mathrm{P}<0,05)$ do tempo de suplementação, as dietas contendo fontes lipídicas apresentaram menores $(\mathrm{P}<0,05)$ concentrações de glicose no soro das novilhas que receberam dietas contendo as fontes lipídicas do que no soro das novilhas alimentadas com a dieta controle. O tempo de suplementação também influenciou $(\mathrm{P}<0,05)$ a glicemia das novilhas e aos 60 dias de suplementação as dieferenças entre as dietas foram mais evidentes (Figura 4). Este resultado de glicemia é coerente com os resultados de ganho de peso e indica que novilhas recebendo dietas não suplementadas com lipídios apresentaram maiores concentrações de glicose circulante e esta foi mais eficientemente utilizada para o ganho de peso. 
Figura 4 - Concentrações de glicose no soro de novilhas alimentadas com grão de soja (GS) e semente de linhaça (SL)

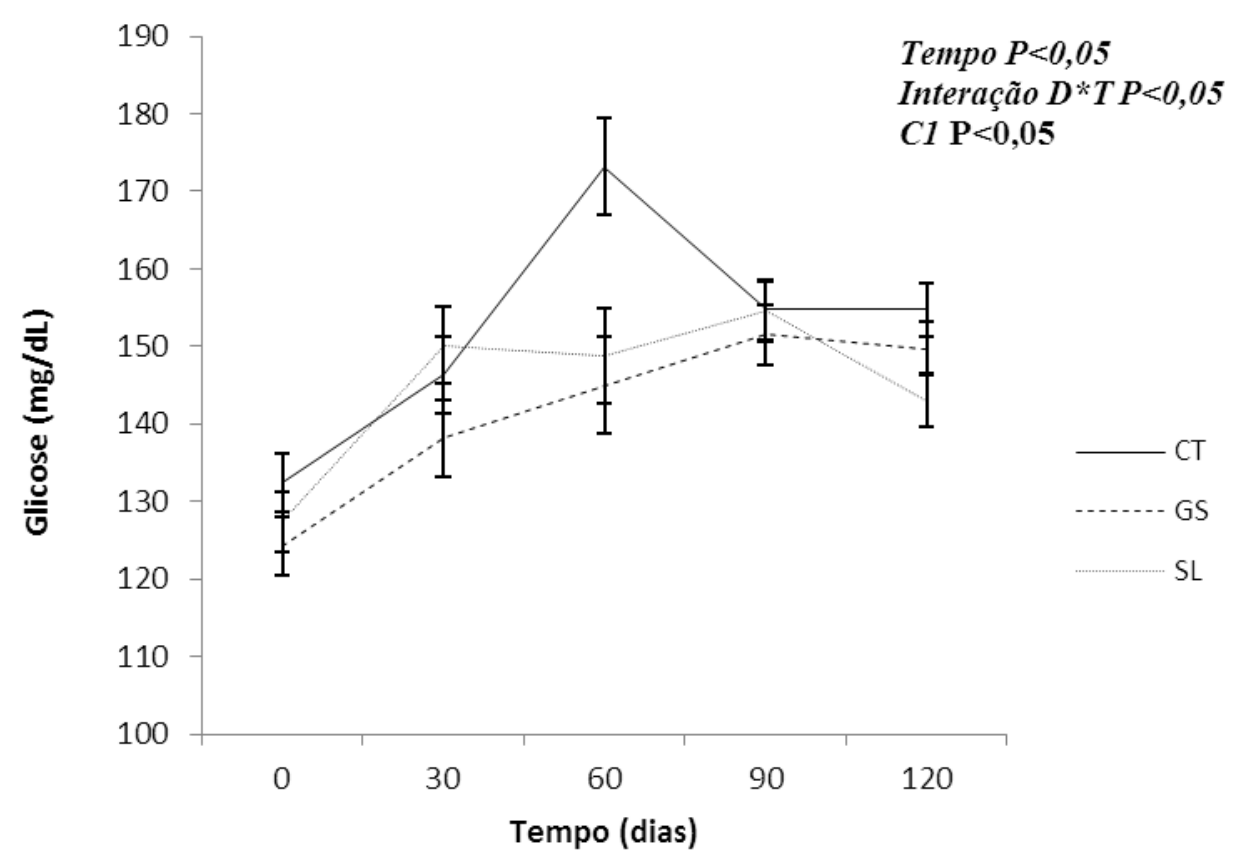

A glicose é considerada um importante metabólito envolvido na regulação do crescimento folicular (TELENI et al., 1989; DOWNING et al., 1991; DOWNING et al., 1995a; DOWNING et al., 1995b; MOLLE et al., 1995). Short; Adams (1989) afirmaram que a glicose é a principal fonte de energia utilizada pelo sistema nervoso, sendo o mediador específico dos efeitos da nutrição na reprodução animal. $\mathrm{O}$ fornecimento de dietas ricas em grãos aos ruminantes altera a população de microrganismos do rúmen, bem como a produção e a proporção de ácidos graxos voláteis produzidos (TELENI et al., 1989). Na realidade, o uso de cereais proporciona maior produção de ácido propiônico (SILVA; LEÃO, 1979). Após sua absorção pela parede ruminal, o ácido propiônico é carreado até o fígado onde é metabolizado até se tornar glicose por meio da gluconeogênese (O'CALLAGHAN; BOLAND, 1999). Durante esse processo, ocorre um aumento dos níveis de glicose circulante na corrente sanguínea (LEURY et al., 1990).

Estudos realizados por Birgel Junior et al. (2007), os valores de referência pré estabelecidos para novilhas holandesas na faixa etária de 3 a 24 meses consistiu em 64,0 e $76,1 \mathrm{mg} / \mathrm{dL}$, inferiores aos valores encontrados nesse estudo, provavelmente devido à diferença do nível energético da dieta. 
Os ruminantes têm basicamente a mesma exigência de glicose para o seu metabolismo que outras espécies, embora o nível de glicose encontrado no sangue seja de 40 a $60 \mathrm{mg} / \mathrm{dL}$ (FRASER, 1991), o que corresponde praticamente à metade do nível encontrado nos outros animais. Existem no mínimo cinco tecidos que exigem glicose: o tecido nervoso, o tecido muscular, o tecido adiposo, as glândulas mamárias e o feto.

Gandra (2012), estudando vacas no período de transição, período de maior exigência energética pelo animal, encontraram concentrações de glicose para vacas da raça holandesa de $64,3 \pm 1,04,70,7 \pm 1,06$ e $60,0 \pm 1,11 \mathrm{mg} / \mathrm{dL}$, quando submetidas a dietas controle e dietas suplementadas com grão de soja e semente de linhaça, respectivamente.

Portanto sugere-se que as novilhas tendem a ter maiores concentrações de glicose sanguínea em relação às vacas já que não tem grandes demandas energéticas como é o caso dos processos de lactação e gestação (GONZALEZ et al., 1993).

Os resultados de experimentos realizados onde se testou a suplementação de lipídeos na dieta de bovinos, demonstraram que não existem diferenças nas concentrações de glicose de acordo com as dietas com alto teor energético, fato este relatado por vários autores (GUTIERREZ et al., 1997; RUAS et al. 2000). Segundo eles, os ruminantes utilizam AGVs como a principal fonte de energia, e alterações entre os estados de fome ou sobre alimentação são rapidamente regulados pela insulina, o que promove um nível praticamente constante nas concentrações de glicose sanguínea.

Estudos também sugerem que efeito de estresse dos animais no momento da colheita sanguínea, podem provocar o aumento dos valores de glicose (RUAS et al. 2000; WEEKES, 1991), podendo justificar níveis numericamente elevados da concentração de glicose plasmática em animais tratados com dieta controle, como apresentado no presente estudo.

As concentrações de colesterol total foram influenciadas $(\mathrm{P}<0,05)$ pelo tempo de suplementação. Houve uma tendência $(\mathrm{P}=0,062)$ de aumento das concentrações de colesterol total nas dietas contendo fontes lipídicas, independentemente do tempo de suplementação. Apesar de não haver interação entre tempo e dieta para esta variável, o desdobramento dos efeitos das dietas ao longo do tempo de suplementação (Figura 5) nos mostra que a medida que aumenta o tempo de suplementação as diferenças entre as dietas aumenta, tornando-se estatisticamente diferente aos 120 dias de suplementação. As diferentes fontes lipídicas suplementadas não diferiram $(\mathrm{P}>0,05)$ entre si. 
Figura 5 - Concentrações de coleterol total no soro de novilhas alimentadas com grão de soja (GS) e semente de linhaça (SL)

Tempo $P<0,05$

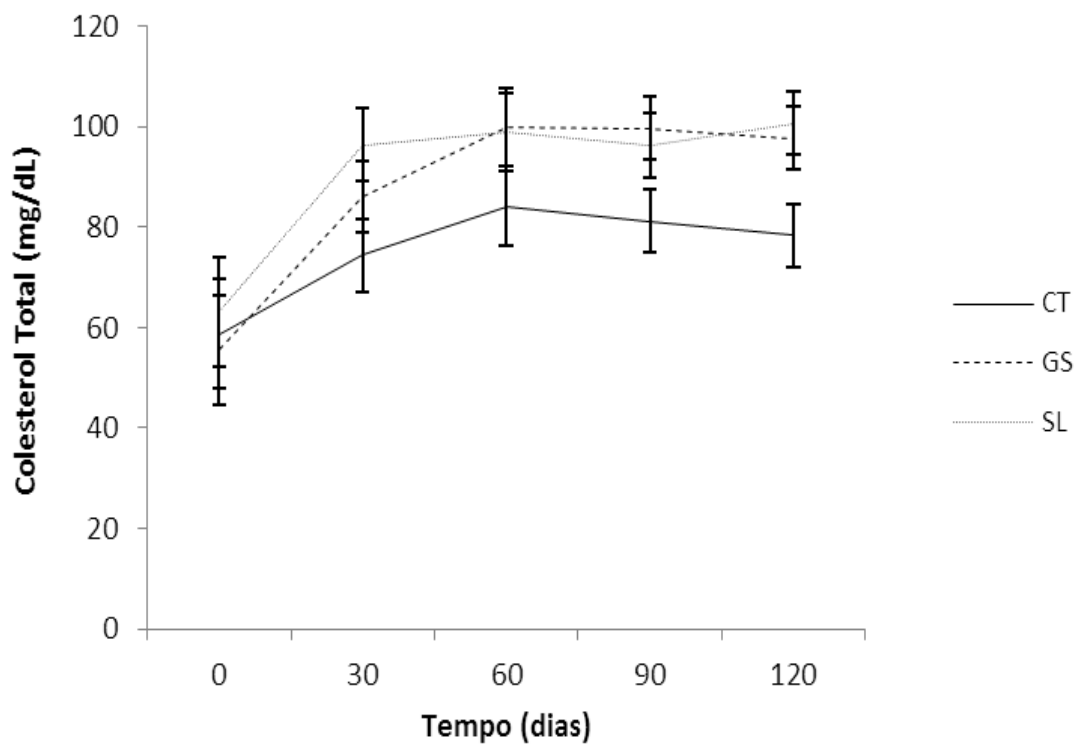

Figura 6 - Concentrações de triglicerídeos no soro de novilhas alimentadas com grão de soja (GS) e semente de linhaça (SL)

Tempo $P<0,05$

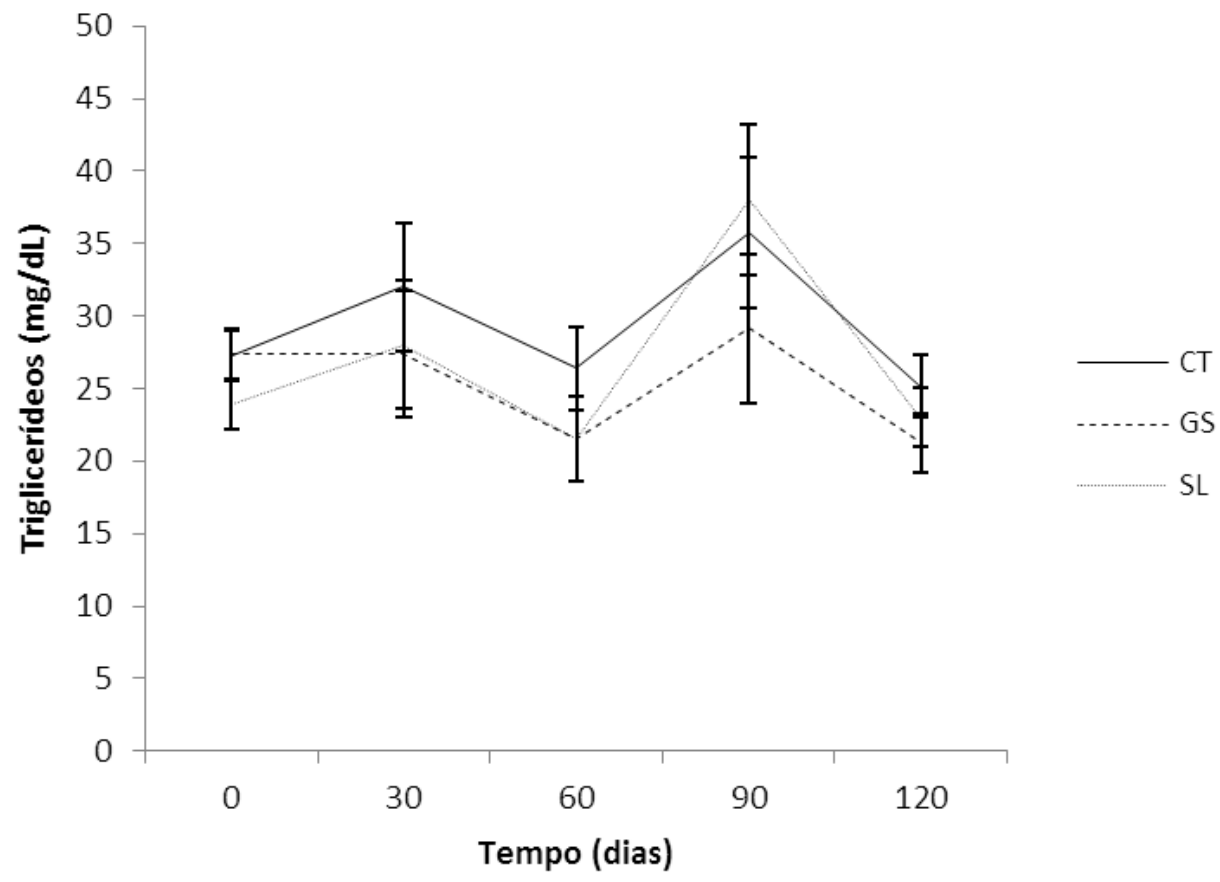


Grummer; Carroll (1991) revisaram diversos estudos nos quais lipídeos foram acrescentados à dieta de vacas de leite e observaram que, em todos eles, as concentrações de colesterol no plasma foram consistentemente elevadas nas dietas com suplementação lipídica, em relação às dietas controle. Utilizando dados com gado de leite e de corte (SANTOS; AMSTALDEN, 1998), foram observados resultados similares aos descritos por aqueles autores.

As concentrações de triglicerideos e as de colesterol VLDL (calculada a partir da concentração de triglicerídeos), independentemente do tempo não foram influenciadas pelas dietas experimentais. Houve efeito $(\mathrm{P}<0,05)$ do tempo de suplementação sobre ambas as concentrações. A concentração máxima observada foi de 34,29 e 5,82 $\mathrm{mg} / \mathrm{dL}$ de triglicerídeos e colesterol VLDL, respectivamente, aos 90 dias de suplementação, à qual não diferiu das concentrações dos mesmos, aos 36 dias pelo teste de Tukey ajustado, à 5\% de probabilidade (Figuras 6 e 7).

Figura 7 - Concentrações de colesterol VLDL no soro de novilhas alimentadas com grão de soja (GS) e semente de linhaça (SL)

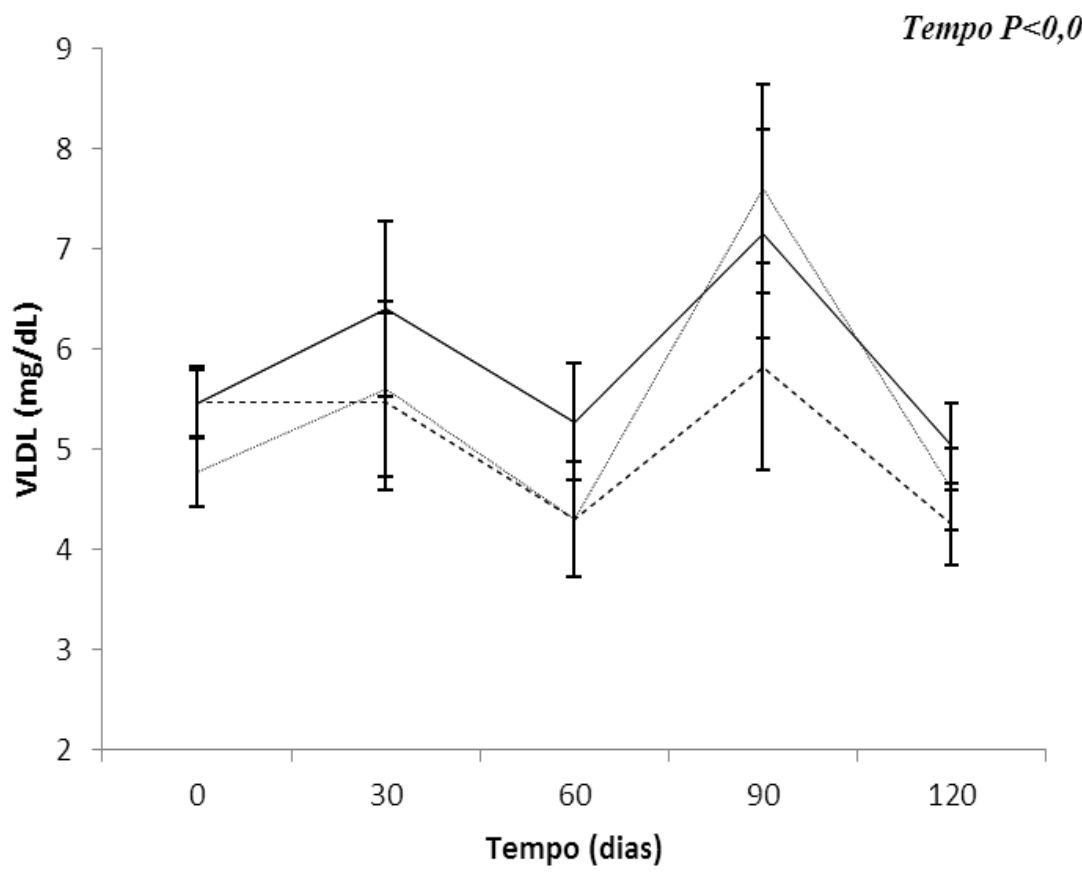

As concentrações de $\mathrm{C}$-HDL não foram influenciadas $(\mathrm{P}>0,05)$ pelas dietas experimentais. Independentemente da dieta fornecida, as concentrações de C-HDL foram menores ao início do fornecimento das dietas experimentais em relação aos demais tempos avaliados (Figura 8). 
Figura 8 - Concentrações de colesterol HDL no soro de novilhas alimentadas com grão de soja (GS) e semente de linhaça (SL)

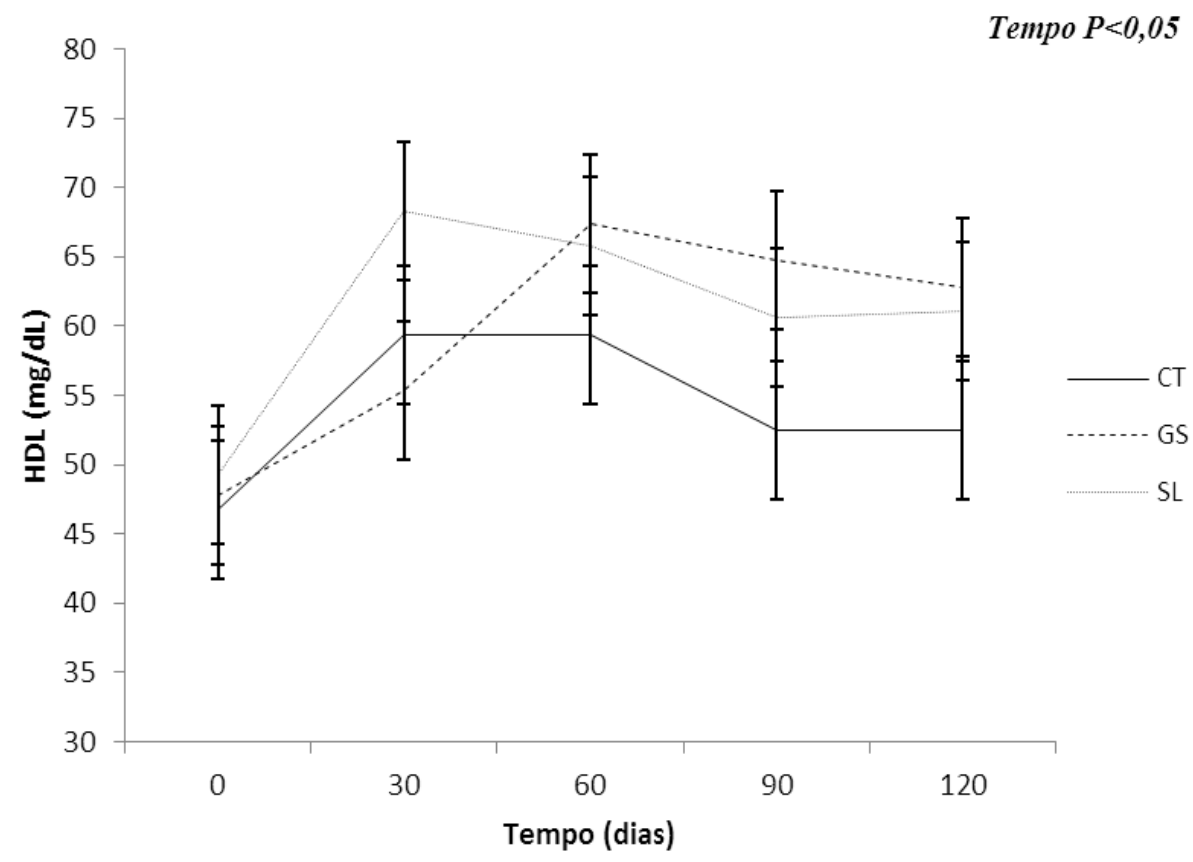

Para as concentrações séricas de C-LDL, não houve interação $(\mathrm{P}>0,05)$ entre os efeitos de dieta e tempo de suplementação. Houve efeito de tempo $(\mathrm{P}<0,05)$, independentemente do da dieta. Houve uma tendência $(\mathrm{P}=0,065)$ de aumento das concentrações de C-LDL nas dietas suplementadas com lipídios, em relação à dieta controle (Figura 9). 
Figura 9- Concentrações de colesterol LDL no soro de novilhas alimentadas com grão de soja (GS) e semente de linhaça (SL)

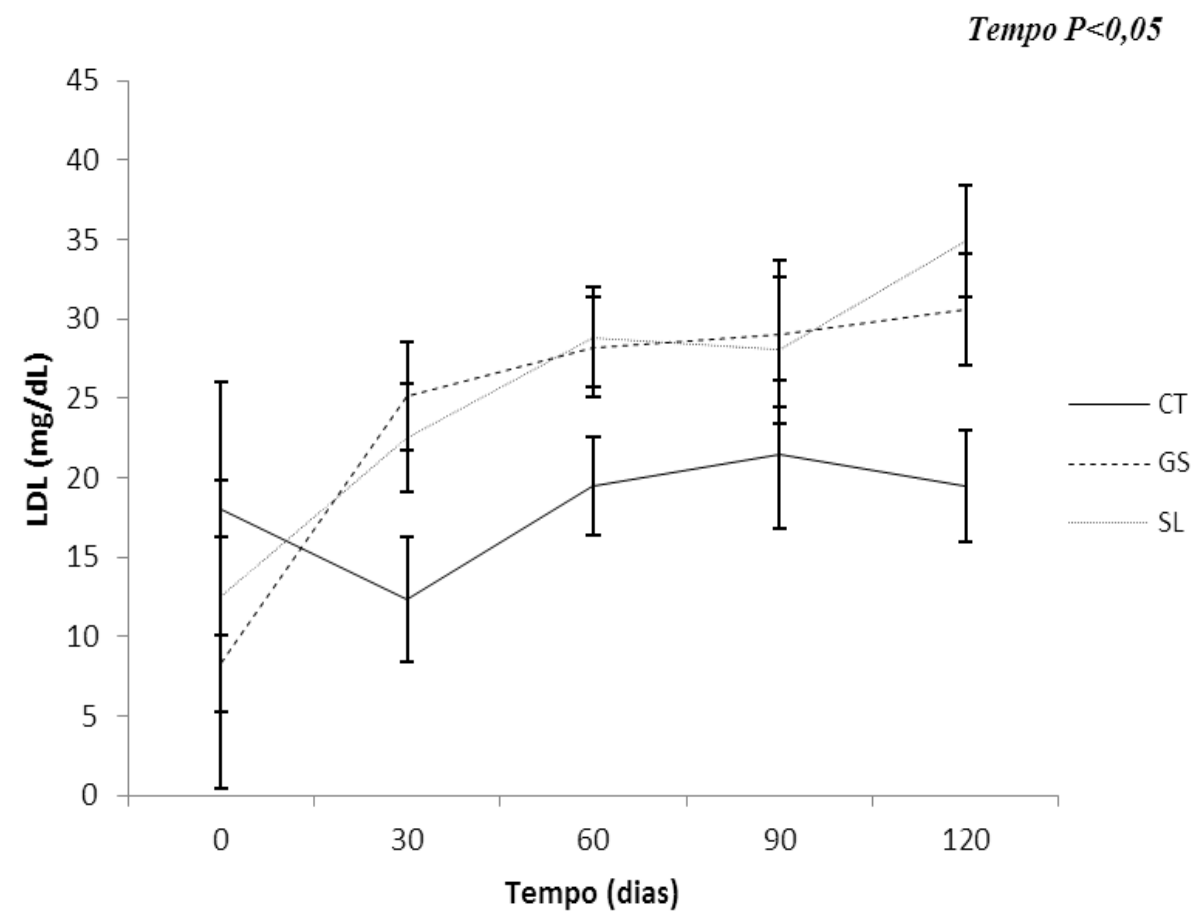

Figura 10 - Concentrações de ureia no soro de novilhas alimentadas com grão de soja (GS) e semente de linhaça (SL)

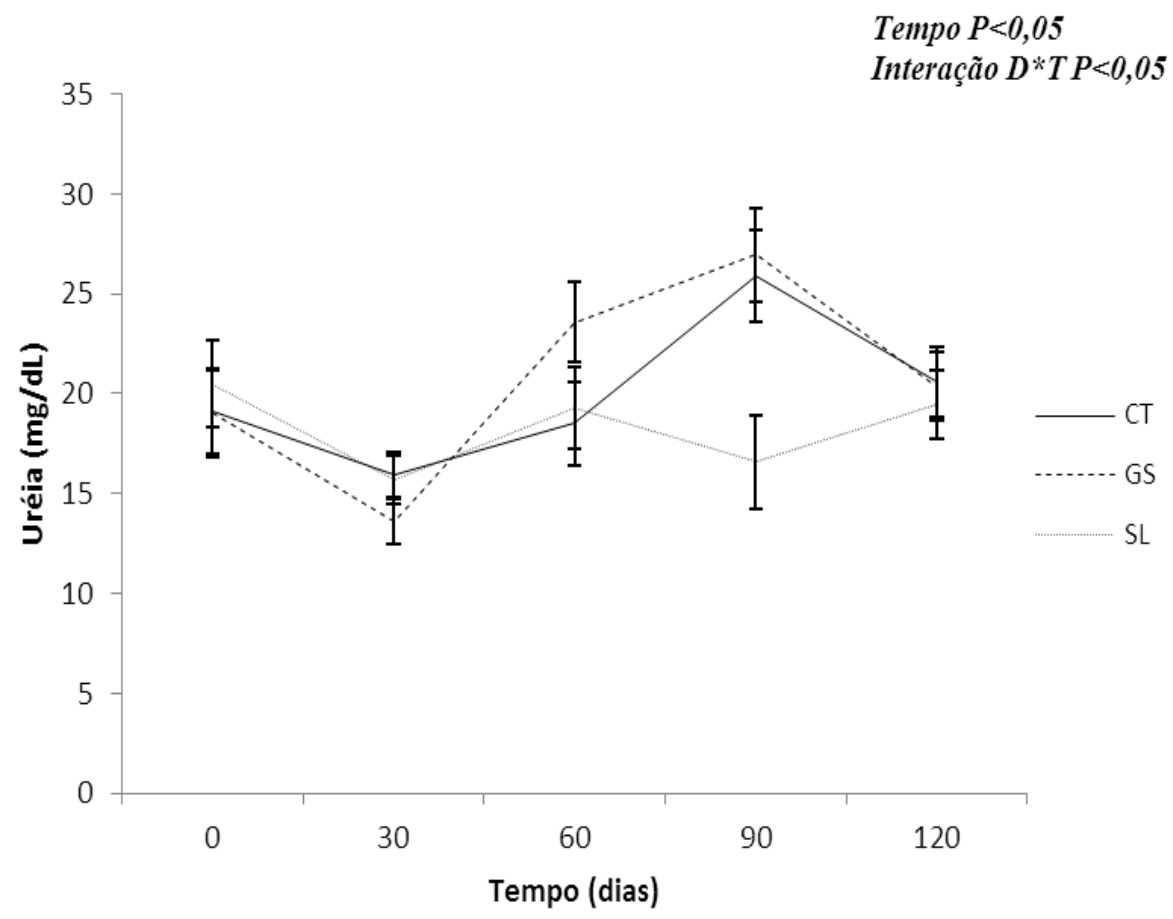


Para as concentrações de ureia no soro, houve efeito de tempo $(\mathrm{P}<0,05)$ e interação $(\mathrm{P}<0,05)$ entre os efeitos de tempo e de dieta. Não houve efeito de dieta $(\mathrm{P}>0,05)$ independente do efeito de tempo. Apenas aos 90 dias de suplementação, as novilhas consumindo a dieta SL apresentaram concentrações de ureia no soro menores que novilhas consumindo GS e CT (Figura 10).

Uma vez circulante, a ureia pode ser facilmente determinada no plasma ou soro dos animais. Por meio dessa determinação, quantifica-se o nitrogênio circulante proveniente da ureia, denominado nitrogênio ureico plasmático.

O nitrogênio ureico plasmático fornece informações relevantes. Roseler et al. (1993) afirmaram que o nitrogênio advindo da degradação proteica ruminal é a principal fonte de ureia plasmática. Além de ser a variável mais utilizada em diferentes estudos, pode ser bom indicador da proteína não utilizada pelo animal (Staples et al., 1993), da taxa de proteína bruta dietética em relação à matéria orgânica fermentável no rúmen (OLTNER et al., 1985) e do metabolismo protéico pós-ruminal (HIGGINBOTHAM et al., 1989). É um bom indicativo também da degradabilidade da proteína no rúmen (ROSELER et al., 1993).

As concentrações plasmáticas de ureia, expressas na forma do nitrogênio ureico plasmático, podem ser utilizadas para monitorar o consumo de proteína dietética, uma vez que o consumo excessivo de proteína verdadeira ou nitrogênio não-protéico pode afetar o desempenho reprodutivo do animal, elevar sua exigência energética e aumentar o custo da ração (BRODERICK; CLAYTON, 1997; OLIVEIRA JÚNIOR et al., 2004).

Portanto, as concentrações de ureia são indicadores de consumo proteico, e como esperado têm uma relação positiva com a dieta.

O teor de N-ureico plasmático está estreitamente relacionado ao metabolismo de nitrogênio $(\mathrm{N})$. Quando a taxa de degradação proteica ruminal excede a taxa de síntese microbiana, o excesso de amônia produzido é absorvido pela parede do rúmen e segue pela corrente sanguínea até o fígado, onde ocorre a conversão de amônia em ureia, que, posteriormente, é excretada na urina, no leite e no fluido uterino (ROSELER et al., 1993). Desse modo, a alta concentração de N-ureico no plasma pode ser indicativo de excesso de amônia no rúmen e pode ter resultado do consumo de proteínas dietéticas de rápida degradação ruminal e de rações com baixa relação NDT:PB (PARK, 1985).

As concentrações de ureia no sangue variam e são influenciadas pelo aporte de proteína e de energia e pela excreção urinária. Animais utilizando dietas ricas em proteína, 
com alto consumo, e não sincronismo entre a degradação da proteína e de carboidratos no rúmen, normalmente levam a maior concentração de ureia no sangue devido o não aproveitamento adequado da proteína (OLTNER; WIKTORSSON, 1983).

Vários trabalhos de pesquisas têm mostrado que o aumento de ureia na circulação sanguínea altera negativamente a reprodução animal (HOWARD et al., 1987; CARROL et al., 1988; BRUCKENTAL et al., 1989; SANTOS; AMSTALDEN, 1998; GARCIA-BAJALIL et al., 1998). O efeito negativo da ureia pode estar relacionado, principalmente, a uma diminuição do pH uterino (ELROD; BUTLER, 1993a, 1993b). Essa redução poderia prejudicar a resposta dos espermatozóides e óvulos (SINCLAIR et al., 2000), o desenvolvimento inicial do embrião e/ou alteração na concentração sanguínea de progesterona e insulina (SANTOS; AMSTALDEN, 1998). Da mesma forma, Fergunson et al. (1993) reportaram que a taxa de concepção no rebanho diminui quando os níveis circulantes de ureia no sangue estão acima de $20 \mathrm{mg} / \mathrm{dl}$.O nível sanguíneo médio de ureia tido como normal em bovinos é de 5 a $20 \mathrm{mg} / \mathrm{dL}$ (ANDREOTI, 1998).

De acordo com Kaneko (1989), os níveis de ureia sanguínea refletem de forma confiável o nível de ingestão de componentes nitrogenados na dieta. Os níveis considerados normais estão entre 16,56 e 42,84 mg/dL, podendo estar aumentados com alimentação com excesso de proteínas ou de fontes de nitrogênio não proteico (WITTWER et al., 1987).

Segundo Haida et al., (1996) o nível médio de ureia sanguínea encontrado em novilhas pesando em média 310Kg sob pastejo foi de 21,55 mg/dL. Entretanto, Elrod (1993); Barton et al. (1996) e Butler et al. (1996), encontraram concentrações de até $21 \mathrm{mg} / \mathrm{dL}$, e sugeriram que o nitrogênio ureico plasmático pode alterar a fertilidade, quando as concentrações ultrapassarem a $18 \mathrm{mg} / \mathrm{dL}$, valores encontrados neste trabalho. Armstrong et al. (2001) demonstraram que a qualidade dos oócitos de folículos pequenos foi correlacionada negativamente com as concentrações de ureia plasmática. Também estudos de Sinclair et al. (2001) relatam que a exposição de oócitos no interior dos folículos, a altos níveis de ureia ou amônia compromete sua capacidade de desenvolvimento a blastocistos durante o cultivo in vitro, o que pode ter ocorrido no presente estudo.

Portanto os níveis de ureia encontrados nesse estudo estão dentro dos supostos níveis padrões determinados normais para a espécie nessa fase como ilustrado na figura 10. 
Figura 11 - Concentrações de proteína total no soro de novilhas alimentadas com grão de soja (GS) e semente de linhaça (SL)

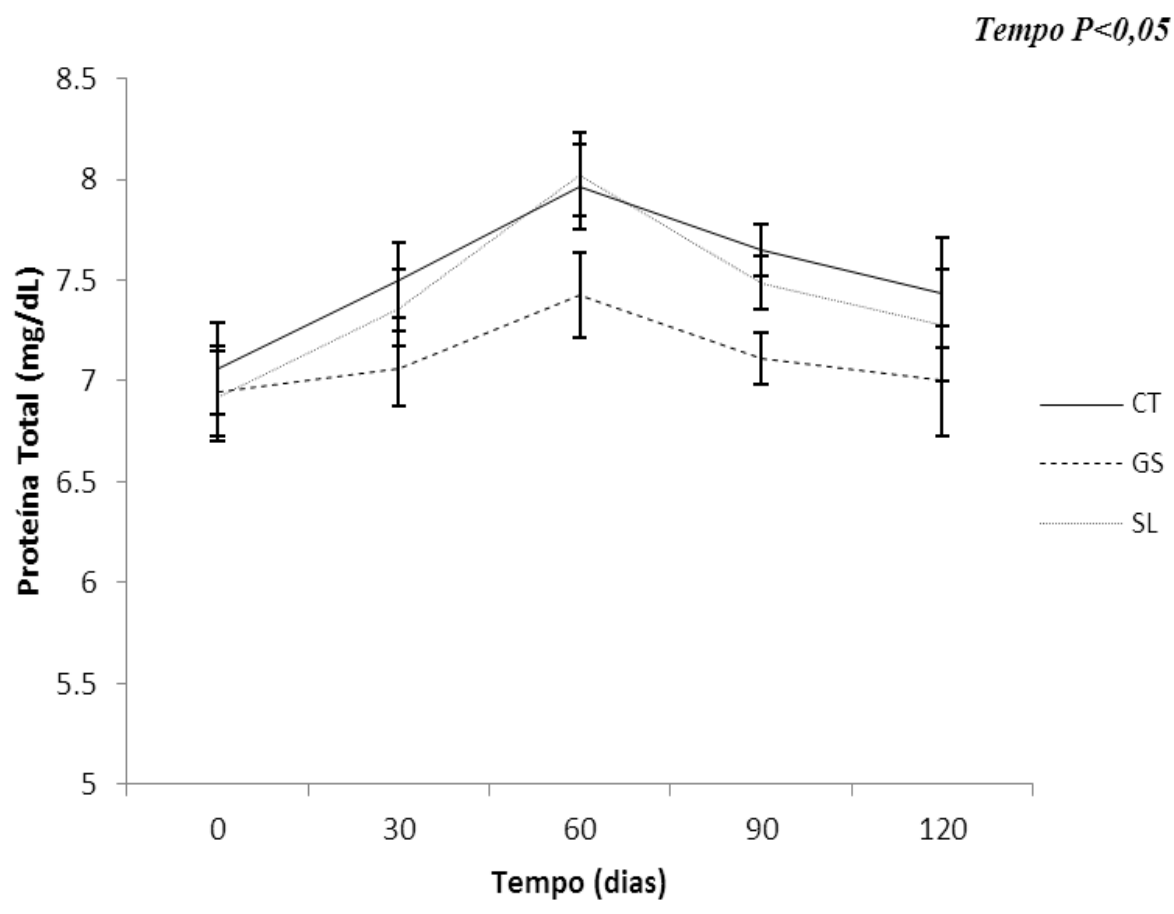

Com relação à proteínas totais foi observado apenas efeito de tempo $(\mathrm{P}<0,05)$ para concentração de proteína total no soro dos animais tratados (Figura 11).

A quantificação de metabólitos sanguíneos pode ser utilizada como uma ferramenta para avaliação do estado de deficiências nutricionais e anormalidades que podem estar ligadas com a infertilidade bovina (ROWLANDS et al., 1980). Vários estudos têm sido realizados com o intuito de verificar as relações e efeitos de metabólitos sanguíneos nos parâmetros reprodutivos, entre principalmente glicose, ureia, colesterol e insulina, mas os resultados são contraditórios. Ureia e glicose podem ser usados para monitorar a ingestão de alimentos proteicos e energéticos, segundo Rowlands et al. (1980). Ruas et al. (2000) não observaram relação dos níveis plasmáticos de colesterol com a fertilidade, enquanto que Kappel et al. (1984) a encontraram. Rutter; Manns (1987) relacionaram a hipoglicemia com a depressão da função reprodutiva, enquanto que Blowey et al. (1973) e Rowlands et al. (1980) não encontraram correlação de níveis plasmáticos de glicose com a fertilidade. Richards et al. (1989) e Vizcarra et al. (1998) associaram concentrações reduzidas tanto de glicose como de insulina com anestro nutricional.

Segundo Bezerra (2006) uma das maiores dificuldades da utilização desta ferramenta é a sua interpretação, devido à falta de valores de referência adequados. Este mesmo autor 
afirma que há uma variação de resultados obtidos, dependendo da idade do animal, raça, estado fisiológico, clima, época do ano, entre outros, o que torna difícil a obtenção de um padrão de comparação que possa garantir a melhor interpretação dos resultados.

\subsection{PARÂMETROS LÍQUIDO FOLICULAR}

\subsubsection{Perfil metabólico}

Houve efeito de tempo $(\mathrm{P}<0,05)$ para todas as variáveis analisadas ao longo de todo período experimental, isso se deve possivelmente à taxa metabólica e maturidade reprodutiva que os animais desenvolveram ao longo do período experimental, pois independentemente do tratamento, os animais obtiveram aumento do peso corporal além de efeito significativo de tempo em todas variáveis sanguíneas, podendo interferir diretamente no metabolismo do fluído folicular.

Semelhante ao presente estudo, Leroy et al. (2004a) observaram que a composição bioquímica do fluido folicular está diretamente correlacionada à composição sérica. Essa correlação é importante, pois alterações nos níveis séricos de metabólicos bioquímicos e hormonais refletem diretamente na constituição do líquido folicular. O líquido folicular pode interferir tanto na função das células da granulosa (esteroidogênese), quanto no desenvolvimento final do oócito (LEROY et al., 2004b).

Tabela 7 - Perfil bioquímico do fluído folicular de novilhas alimentadas com dietas contendo fontes lipídicas suplementares

\begin{tabular}{lcccccccccc}
\hline \multirow{2}{*}{ Item } & \multicolumn{3}{c}{ Dietas $^{1}$} & \multirow{2}{*}{ Média } & EPM $^{2}$ & \multicolumn{4}{c}{ Probabilidades $(P)^{3}$} \\
\cline { 2 - 7 } \cline { 7 - 10 } & CT & GS & SL & & & Dieta & Tempo & I D $^{*} T^{4}$ & C1 & C2 \\
\hline Glicose & 92,96 & 92,38 & 92,42 & 94,59 & 1,27 & 0,987 & 0,002 & 0,660 & 0,874 & 0,993 \\
Colesterol Total & 29,98 & 24,69 & 33,29 & 31,75 & 1,41 & 0,316 & 0,011 & 0,004 & 0,819 & 0,135 \\
Triglicerídeos & 15,33 & 7,95 & 9,37 & 10,11 & 1,17 & 0,046 & 0,010 & 0,034 & 0,015 & 0,652 \\
Ureia & 19,78 & 14,96 & 13,19 & 17,72 & 1,16 & 0,192 & $<0,001$ & $<0,001$ & 0,096 & 0,660 \\
\hline
\end{tabular}

${ }^{1}$ Dietas: CT: Controle; GS: Grão de Soja; SL: Semente de Linhaça; ${ }^{2}$ EPM: Erro padrão da média; ${ }^{3}$ Probabilidade: tempo; ${ }^{4}$ Interação dieta*tempo (I D*T); C1 (contraste 1: CT vs fontes lipídicas; C2 (contraste 2: GS vs SL).

A composição bioquímica do fluido folicular, que deriva principalmente do plasma e de fatores produzidos localmente por células foliculares, reflete as diferentes condições 
reprodutivas e processos fisiológicos ou patológicos do plasma (FAHIMINIYA; GÉRARD, 2010).

O líquido folicular é considerado transudado do plasma sanguíneo. Andersen et al. (1976) relataram que todos os componentes do fluido folicular de origem sanguínea, como lipídeos, proteínas e eletrólitos, têm concentração intra-folicular relacionada à plasmática. Algumas outras substâncias produzidas pelas células foliculares apresentam concentração do líquido folicular, nem sempre diretamente relacionadas à plasmática.

A densidade energética da dieta parece ser um dos principais fatores envolvidos no crescimento folicular, ovulação e desenvolvimento embrionário. Trabalhos com ovelhas têm mostrado que um aumento no nível de energia da dieta em curto prazo aumenta o número de folículos e, por sua vez, a taxa de ovulação (HARESIGN, 1981; TELENI et al., 1989; LEURY et al., 1990; MOLLE et al., 1995). Embora os bovinos sejam espécies monovulatórias, parece haver efeito semelhante do aumento do nível de energia da dieta sobre o crescimento folicular (MAURASSE et al., 1985; GUTIERREZ et al., 1997).

Diferentemente das concentrações séricas, a concentração de glicose no fluido folicular não foi influenciada pelas dietas experimentais $(\mathrm{P}>0,05)$. Houve apenas efeito do tempo de suplementação (Figura 12).

Figura 12 - Concentrações de glicose no fluido folicular de novilhas alimentadas com grão de soja (GS) e semente de linhaça (SL)

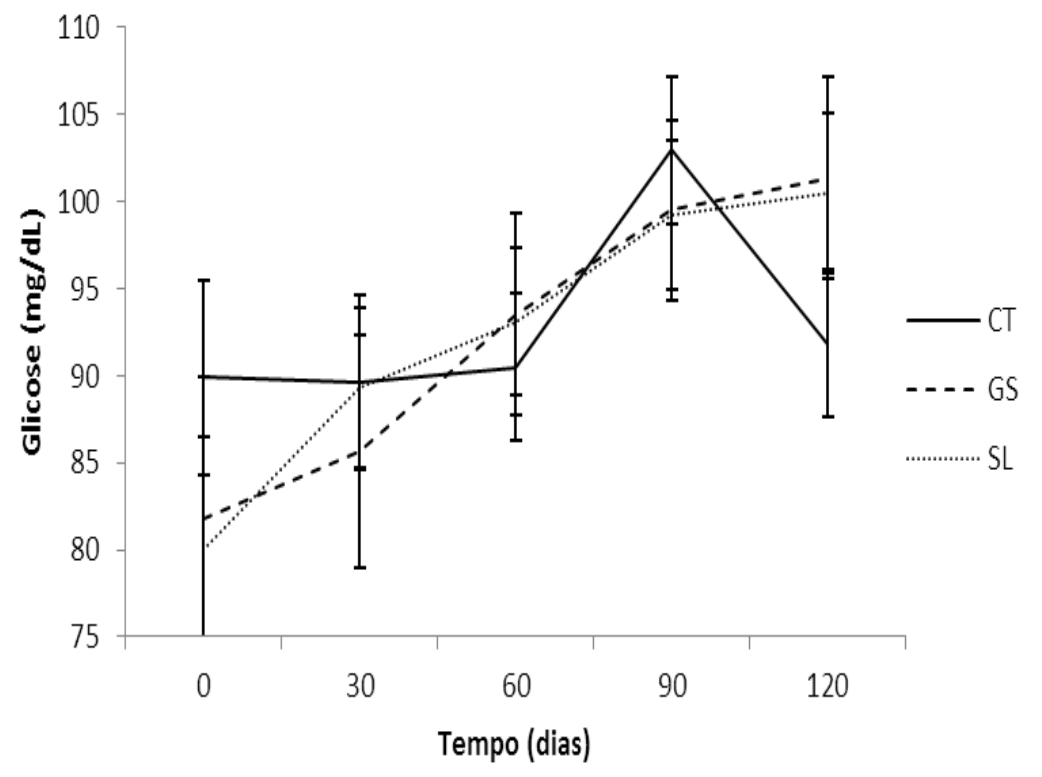

Foi observada interação $(\mathrm{P}<0,05)$ entre os efeitos de tempo e dieta para as concentrações de colesterol total, triglicerídeos e ureia no fluido folicular (Tabela 7). Para as concentrações de colesterol total, não houve efeito de dieta $(\mathrm{P}>0,05)$, independente do tempo. 
O desmembramento da interação nos mostra que aos 6 dias de suplementação, a concentração de colesterol era maior no fluido folicular das novilhas alimentadas com a dieta controle em relação as demais. Com o passar do tempo, observou-se um aumento da concentração de coleterol total nas novilhas alimentadas com a dieta SL, sendo que esta foi superior aos resultados das novilhas alimentadas com a dieta CT aos 66 e 126 dias de suplementação. Já para as novilhas alimentadas com a dieta GS, não se observou este aumento. As concentrações de colesterol não diferiram da dieta SL aos 6 dias de suplementação e não diferiram da dieta CT nos demais tempos avaliados (Figura 13).

Figura 13 - Concentrações de coleterol total no fluido folicular de novilhas alimentadas com grão de soja (GS) e semente de linhaça (SL)

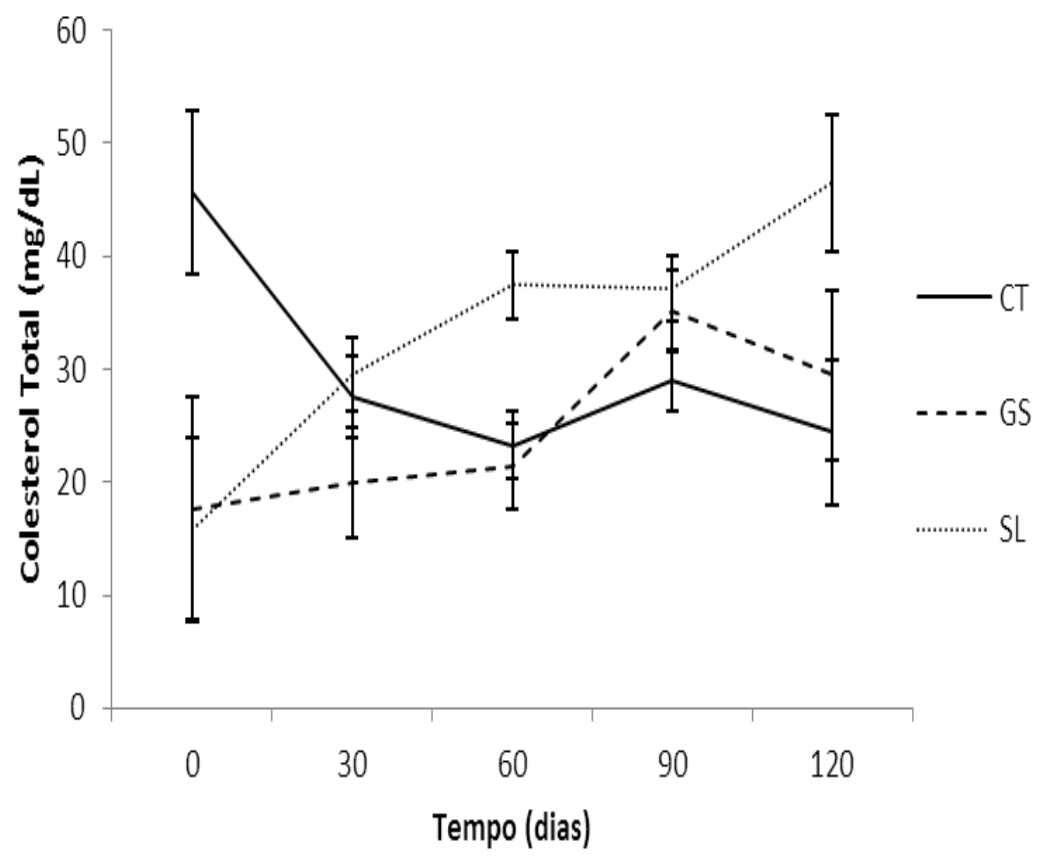

O colesterol é o substrato utilizado pelas células luteínicas para a síntese de progesterona e, nos bovinos, a lipoproteína de alta densidade (HDL) é a principal fonte deste metabólito (GRUMMER; CARROL, 1988), por ser esta, a mais abundante no plasma e no fluido folicular (GRUMMER; CARROL, 1991).

A concentração sérica de colesterol total em bovinos pode variar entre vacas $(172,8$ $\mathrm{mg} / \mathrm{dL}$ ) e novilhas (121,4 mg/dL) (ARAVE et al., 1974), e durante o ciclo estral apresenta padrão cíclico (TALAVERA et al., 1985) com redução durante a fase luteínica, que é o resultado, provavelmente, de sua utilização como substrato para a síntese de progesterona (CHRISTIE et al., 1979). 
A glicose e colesterol podem atuar positivamente sobre a qualidade dos oócitos das vacas Bos indicus. O colesterol por ser o precursor dos hormônios esteróides e a glicose por ser a principal fonte de energia e agir no sistema nervoso central, modulando a síntese e liberação de GNRH pelo hipotálamo e, conseqüentemente, de LH e FSH (DISKIN et al., 2003). Além disso, a glicose induz à liberação de insulina e, consequentemente, de IGF-1, os quais modulam a capacidade esteroidogênica do folículo, além de estimular a proliferação das células da teca (SPICER; STEWART, 1996) e da granulosa (SPICER; ALPIZAR; ECHTERNKAMP, 1993). Essas funções são importantes para o desenvolvimento do folículo e do oócito após a formação do antro folicular.

O fluido folicular bovino contém apenas HDL, cujas concentrações se elevam com a maturação folicular, quando ocorre aumento da vascularização e da permeabilidade em torno do folículo dominante. Dessa forma, o HDL contribui como fonte de colesterol para o tecido ovariano, principalmente durante a fase periovulatória (BRANTMEIER et al., 1987). Atribui-se aos triglicerideos a função de reserva estratégica de energia que pode ser requisitada em momentos críticos do metabolismo ou durante eventos reprodutivos. Por outro lado, o excesso de lipídeos no fluido folicular, induzido por dietas ricas em gordura, pode causar lipotoxicidade em células ovarianas, disfunção mitocondrial, estresse no retículo endoplasmático, aumento dos níveis de cálcio folicular, apoptose, anovulação e diminuição das taxas de fertilização em camundongos e mulheres (WU et al., 2010).

Para as concentrações de triglicerídeos no fluido folicular, observou-se que as novilhas alimentadas com a dieta controle apresentaram maiores $(\mathrm{P}<0,05)$ concentrações deste no fluido que as novilhas alimentadas com dietas suplementadas com lipídios e que este efeito foi dependente do tempo $(\mathrm{P}<0,05)$.

O desdobramento da interação observada (Figura 14) nos mostra que este efeito foi evidente aos 6 dias de suplmentação e deixou de existir com a evolução do tempo de suplementação. 
Figura 14 - Concentrações de triglicerídeos no fluido folicular de novilhas alimentadas com grão de soja (GS) e semente de linhaça (SL)

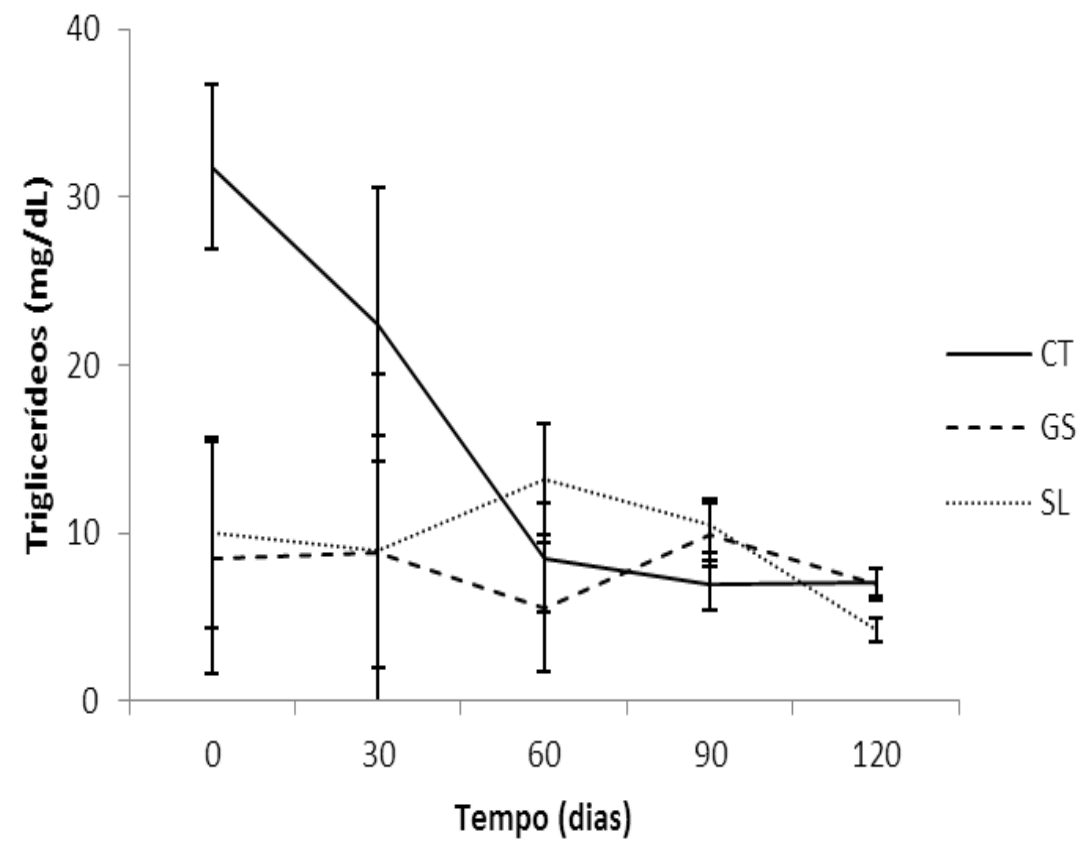

Figura 15 - Concentrações de ureia no fluido folicular de novilhas alimentadas com grão de soja (GS) e semente de linhaça (SL)

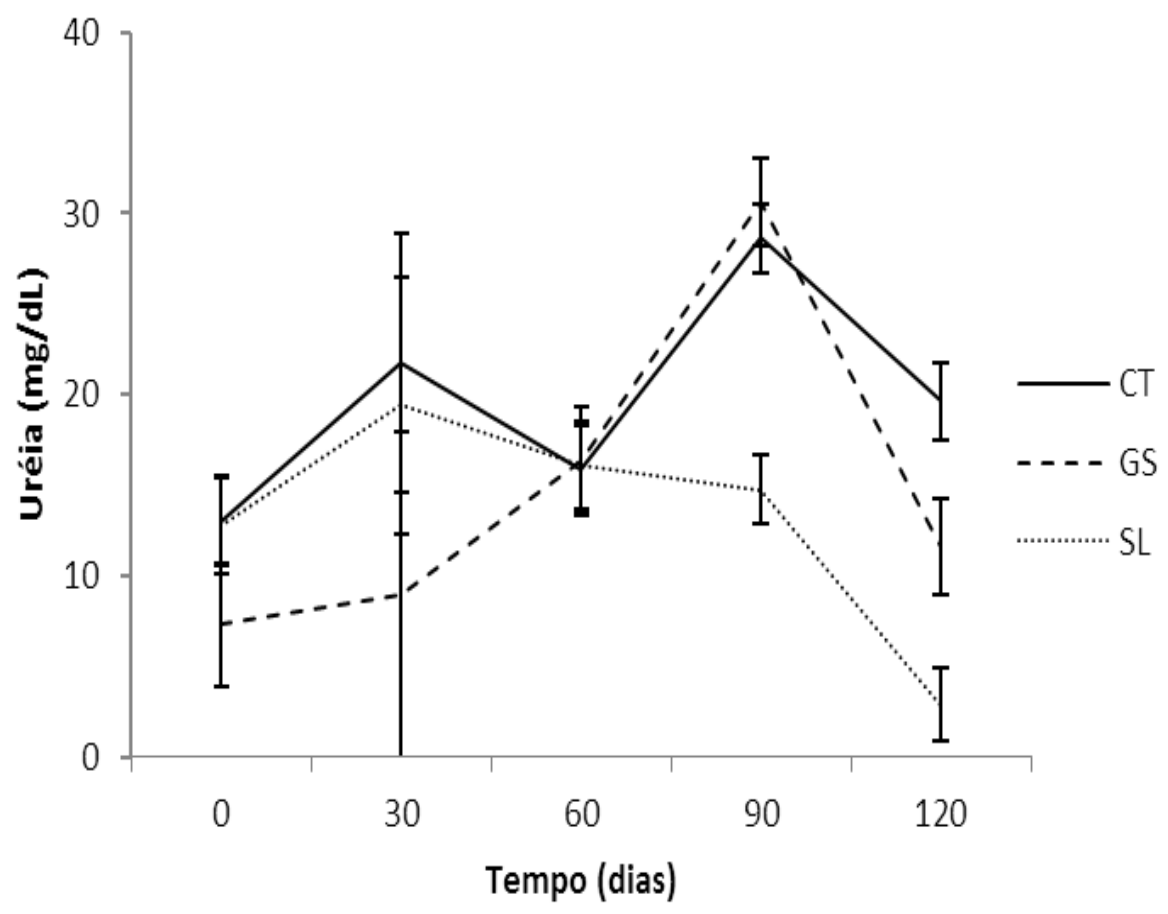


Para as concentrações de ureia no fluido folicular observou-se interação entre os efeitos de dieta e de tempo de suplementação. Nos três primeiros tempos avaliados $(0,30$ e 60 dias de suplementação), as dietas não influenciaram nesta variável. Aos 90 e 120 dias, as novilhas consumindo a dieta SL tiveram concentrações menores de ureia no fluido folicular que as novilhas da dieta controle. Como aos 0 e 30 dias de suplementação, a dieta GS levou a concentrações de ureia numericamente menores que a dieta controle, houve uma tendência $(\mathrm{P}=0,096)$ de redução da concentração de ureia, independente do tempo, para as dietas suplementadas com lipídios (Figura 15).

Os compostos nitrogenados, como a ureia e a amônia, são substâncias que podem afetar o desenvolvimento embrionário de mamíferos. Tal afirmação é baseada em estudos in vitro e in vivo, nos quais a amônia gerada fisiologicamente pelo metabolismo celular e pelo catabolismo proteico foi tóxica a gametas e embriões murinos, ovinos e bovinos em cultura (GARDNER; LANE, 1993; MCEVOY et al., 1997; SINCLAIR et al., 1998).

\subsection{QUALIDADE OOCITÁRIA E EMBRIONÁRIA}

O estado nutricional está entre os fatores que mais afetam o desempenho reprodutivo da fêmea bovina (WEBB et al., 2004). No entanto, os mecanismos fisiológicos específicos através dos quais a dieta influencia a reprodução permanecem pouco entendidos e ainda precisam ser elucidados (GONG, 2002; DISKIN et al., 2003), principalmente porque essa relação é complexa e as respostas são muito variáveis e inconsistentes (BOLAND; LONERGAN, 2003).

Tabela 8 - Oócitos, qualidade oocitária e produção de embriões de novilhas holandesas alimentadas com dietas suplementadas com diferentes sementes de oleaginosas por diferentes períodos de tempo

\begin{tabular}{|c|c|c|c|c|c|c|c|c|c|c|}
\hline \multirow{2}{*}{ Item } & \multicolumn{3}{|c|}{ Dietas $^{1}$} & \multirow{2}{*}{ Média } & \multirow{2}{*}{$\mathrm{EPM}^{2}$} & \multicolumn{5}{|c|}{ Probabilidades $(P)^{3}$} \\
\hline & $\mathrm{CT}$ & GS & SL & & & Dieta & Tempo & $\mathrm{I} \mathrm{D}^{*} \mathrm{~T}^{4}$ & $\mathrm{C} 1$ & $\mathrm{C} 2$ \\
\hline \multicolumn{11}{|c|}{ Oócitos } \\
\hline Totais & 8,16 & 5,47 & 6,01 & 6,56 & 0,693 & 0,668 & 0,378 & 0,307 & 0,386 & 0,864 \\
\hline Viáveis & 4,63 & 3,47 & 3,75 & 3,95 & 0,425 & 0,789 & 0,129 & 0,278 & 0,510 & 0,874 \\
\hline G1 & 0,22 & 0,16 & 0,29 & 0,22 & 0,067 & 0,747 & 0,025 & 0,161 & 0,976 & 0,451 \\
\hline G2 & 1,09 & 0,69 & 0,63 & 0,80 & 0,124 & 0,466 & 0,238 & 0,478 & 0,227 & 0,894 \\
\hline G3 & 3,31 & 2,63 & 2,82 & 2,93 & 0,311 & 0,883 & 0,172 & 0,399 & 0,637 & 0,895 \\
\hline Cultivados & 7,03 & 4,41 & 4,51 & 5,31 & 0,618 & 0,609 & 0,422 & 0,342 & 0,328 & 0,972 \\
\hline
\end{tabular}




\begin{tabular}{llccccccccc} 
Clivados & 3,16 & 1,63 & 2,54 & 2,43 & 0,350 & 0,574 & 0,560 & 0,318 & 0,401 & 0,535 \\
& \multicolumn{2}{l}{ Embriões } & & & & & & & & \\
Embriões & 0,63 & 0,31 & 0,25 & 0,40 & 0,116 & 0,633 & 0,040 & 0,693 & 0,263 & 0,859 \\
& \multicolumn{2}{c}{ Taxas $\left(1.10^{-2}\right)$} & & & & & & & & \\
Viáveis $^{5}$ & 57,24 & 70,40 & 67,57 & 65,29 & 2,521 & 0,487 & 0,487 & 0,320 & 0,026 & 0,641 \\
Clivagem $^{6}$ & 51,28 & 33,16 & 51,22 & 44,90 & 3,853 & 0,902 & 0,902 & 0,680 & 0,340 & 0,164 \\
Embriões $^{7}$ & 6,44 & 4,24 & 8,27 & 6,79 & 1,579 & 0,274 & 0,027 & 0,875 & 0,964 & 0,415 \\
\hline
\end{tabular}

${ }^{1}$ Dietas: CT: Controle; GS: Grão de Soja; SL: Semente de Linhaça; ${ }^{2}$ EPM: Erro padrão da média; ${ }^{3}$ Probabilidade: tempo; ${ }^{4}$ Interação dieta*tempo (I D*T); C1 (contraste 1: CT vs fontes lipídicas; C2 (contraste 2: GS vs SL); ${ }^{5}$ Taxa de Viáveis: oócitos viáveis /oócitos totais; ${ }^{6}$ Taxa de Clivados: embriões clivados / oócitos cultivados; ${ }^{7}$ Taxa de embriões: embriões / oócitos cultivados.

Não foi observado efeito $(\mathrm{P}>0,05)$ de dieta, interação tempo x dieta e contraste 2 (C2) (GS vs SL) sobre o total de oócitos aspirados, oócitos viáveis, oócitos de grau I, II, III, cultivados e clivados, bem como de embriões clivados (nº e \%) e viáveis (\%).

Houve efeito $(\mathrm{P}<0,05)$ de tempo para o número de oócitos classificados em Grau I. Apesar de não diferirem significativamente, as médias observadas para o tratamento ômega 3 (SL) são numericamente maiores que as observadas para os demais tratamentos $(0,22 ; 0,16$ e 0,29 para as dietas CT, GS e SL, respectivamente), pois tiveram maior número de oócitos classificados grau I por aspiração folicular, (significando esses de melhor qualidade em relação aos graus II e III). A linhaça possui 52\% do total dos ácidos graxos na forma de ácido linolênico (ROMANS et al., 1995), o que segundo Petit et al. (2002), resulta em maior número de folículos entre 5,0 e 9,9 mm de diâmetro. Este resultado pode ser um indicativo de melhora na qualidade oocitária em novilhas, apesar de, neste estudo, não ter sido observado efeito estatístico de dieta para tal variável, o que pode estar relacionado ao limitado número de animais por tratamento.

Os ácidos graxos poli-insaturados (AGPs) podem elevar a fertilidade em bovinos por diferentes caminhos. Nos ovários, há relatos de efeito dos ácidos graxos sobre o número e tamanho de folículos ovarianos (LUCY et al., 1991; ROBINSON et al., 2002; BILBY et al., 2006), tamanho do CL (RAES et al., 2004; BILBY et al., 2006) e na qualidade oocitária (KIM et al., 2001; ZERON et al., 2002). Além disso, outros estudos também observaram influência de dietas contendo ácidos graxos sobre a qualidade embrionária (KOJIMA et al., 1997; CHILDS et al., 2008a; CERRI et al., 2009b) e a concentração circulante de prostaglandinas e hormônios esteroides (RYAN et al., 1992; THOMAS et al., 1997; PETIT et al., 2002; CHILDS et al., 2008b). 
$\mathrm{Na}$ avaliação dos contrastes ortogonais, foi observado efeito $(\mathrm{P}<0,05)$ para o contraste 1 (CT vs GS+SL) quando se analisou a taxa de oócitos viáveis, onde a dieta CT apresentou menor desempenho em relação as dietas lipídicas (57,24 vs 70,40 + 67,57) (Figura 16).

Houve efeito $(\mathrm{P}<0,05)$ de tempo para o número de embriões, onde a média de embriões por tratamento foi maior numericamente para os animais pertencentes ao grupo da dieta sem suplementação lipídica (CT), e o efeito de tempo foi evidente na OPU 60, no mesmo tempo de suplementação que a glicemia no soro das novilhas foi influenciada, aos 60 dias de suplementação (Figura 4 e 24).

Nos estudos de Diskin (2003) foi demonstrado que a glicose e colesterol podem atuar positivamente sobre a qualidade dos oócitos das vacas Bos indicus. O colesterol por ser o precursor dos hormônios esteróides e a glicose por ser a principal fonte de energia e agir no sistema nervoso central, modulando a síntese e liberação de GnRH pelo hipotálamo e, conseqüentemente, de LH e FSH.

Segundo Rutter; Manns $(1987 ; 1988)$ a glicose é o metabólito que altera a amplitude de liberação de LH (hormônio luteinizante) que atua no desenvolvimento final e ovulação do folículo dominante (GINTHER et al., 1998; MIHM; AUSTIN, 2002; WEBB et al., 2004).

Mccaughey et al. (1988) estudando os efeitos da glicose na função reprodutiva de vacas mantidas em níveis nutricionais adequados, não observaram alterações nos padrões de LH. Rutter; Manns (1986) em trabalho semelhante com ovelhas, concluíram que o conteúdo de hormônios na hipófise e hipotálamo, bem como a concentração de receptores não foram alterados quando níveis de glicose são fornecidos a animais em alimentação adequada.

Houve efeito $(\mathrm{P}<0,05)$ de tempo para taxa ou porcentagem de embriões, o qual diferentemente do número de embriões, as médias maiores foram atribuídas à dieta com fonte de ômega 3 (SL) (Figura 25). O mesmo ocorreu com os níveis de colesterol total no perfil bioquímico sanguíneo e fluído folicular (Figura 5 e 13). Esse efeito pode ter ocorrido devido ao número de oócitos classificados grau I nesse tratamento, onde se observou oócitos de melhor qualidade. Logo, estes resultados podem ser explicados pela hipótese vinculada à síntese de progesterona, pois o fornecimento de gordura aumenta as concentrações de colesterol sanguíneo (LAMMOGLIA et al., 1997) e este possui relação de causa e efeito sobre a síntese de progesterona, por ser precursor da mesma (LAMMOGLIA et al., 2000; OLDICK et al., 1997).

Os oócitos recuperados foram classificados em grau I (melhor qualidade, citoplasma homogêneo) II, III (pior qualidade, podendo conter citoplasma granular). Numericamente as médias dos oócitos classificados em grau III $(2,93)$ foram maiores em relação aos de grau I e II (0,22 e 0,80, respectivamente) (Figuras 18, 19, 20 e 21). O mesmo ocorreu nos estudos de Bacelar (2010), onde avaliou novilhas da raça Nelore (Bos taurus indicus) não gestantes, sob regime de pastagem, observaram uma predominância de folículos $<5 \mathrm{~mm}$ nos tratamentos testados 
(animais protocolados, sincronização hormonal), com média por animal e por aspiração de 5,5 e 8,7 nos animais sincronizados, o qual em ambos os tratamentos ocorreu predominância de oócitos de Grau III, similar as médias avaliadas no presente estudo. A superioridade de produção de oócitos por raças zebuínas já foi demonstrada por vários autores (NONATO JÚNIOR et al, 2004; RUBIN et al., 2004). As médias de oócitos recuperados por animal no presente trabalho foram similares as usualmente encontradas em bovinos da raça Nelore.

A inclusão de gordura na dieta pode alterar o desempenho reprodutivo de ruminantes.

Estes efeitos podem ser dependentes do perfil de ácidos graxos da fonte de gordura (OLDICK et al., 1997) e, também, da relação de causa e efeito entre a progesterona e o colesterol (LAMMOGLIA et al., 2000).

Os resultados observados com o uso de grão de soja na qualidade oocitária e embrionária neste estudo, segundo estudos de Downey (1990) ocorreram devido a alta concentração de ácido linoleico presente nesse grão, o qual pode ser responsável pela secreção prematura de prostaglandina (PETIT et al., 2002), pois esta exerce o papel de regressão funcional do corpo lúteo (OLDICK et al., 1997). No entanto, os mecanismos envolvidos na síntese de prostaglandina ainda são complexos (PETIT et al., 2002).

Os ácidos graxos poli-insaturados (AGP) que compõem os ovócitos e embriões (MCEVOY et al., 2000; KIM et al., 2001; FERREIRA et al., 2010) fornecem energia para os processos relacionados à maturação e competência ovocitária (KIM et al., 2001) e para o desenvolvimento embrionário (WATHES et al., 2007). Além disso, fazem parte da membrana plasmática, alterando sua fluidez que é essencial para o desenvolvimento celular durante e após a fecundação (MCEVOY et al., 2000; FOULADI-NASHTA et al., 2007), bem como afetam a resistência celular à técnica de criopreservação (CLANDININ et al., 1991; ZERON et al., 2002).

Jorritsma et al. (2004) observaram que altas concentrações de ácidos graxos nãoesterificados (AGNEs), que ocorrem em casos de subnutrição, reduzem a proliferação in vitro de células da granulosa, retardando a maturação do oócito, prejudicando, desta forma, a produção de blastocistos. Assim, o efeito nutricional sobre a qualidade do oócito pode contribuir para a baixa fertilidade de vacas leiteiras de alto rendimento (ROYAL et al., 2000). Leroy et al., (2004b), sugerem que também pode haver um componente genético específico para esse efeito adverso.

Fouladi-Nashta et al. (2007) estudaram os efeitos dos AGs da dieta sobre a qualidade do oócito em vacas leiteiras em lactação, que foram alimentadas com dietas contendo níveis altos $(0,8 \mathrm{~kg} / \mathrm{d})$ ou baixos $(0,2 \mathrm{~kg} / \mathrm{d})$ de sais de cálcio de óleo de palma, e os oócitos foram coletados por OPU. Durante o cultivo in vitro, uma maior proporção de oócitos fertilizados do grupo tratado com alto teor de gordura desenvolveu-se até o estádio de blastocisto. Os mesmos autores compararam também os sais de cálcio de óleo de palma com gorduras 
protegidas na forma de soja (ricas em ácido linoleico) ou linhaça (ricas em ácido linolênico). A taxa de clivagem e a qualidade dos oócitos foram menores nas vacas que receberam lipídeos com altos teores de ácido linoleico ou linolênico. Não se sabe se estes efeitos são devido às diferenças na estrutura da membrana do oócito, status oxidativo ou AGs como fonte de energia.

Mudanças na ingestão de energia são capazes de influenciar negativamente a morfologia e a competência de oócitos. Assim como foi observado neste estudo, onde podemos observar que a dieta controle apresentou médias superiores na quantidade de oócitos e oócitos viáveis em relação aos grupos tratados.

Uma grande variedade de dietas tem mostrado afetar não somente o crescimento folicular, mas também a qualidade do oócito (ARMSTRONG et al., 2001; BOLAND et al., 2001).

Figura 16 - Número de oócitos totais obtidos a partir das OPUs realizadas com os animais dos grupos experimentais: CT: Controle; GS: Grão de Soja; SL: Semente de Linhaça

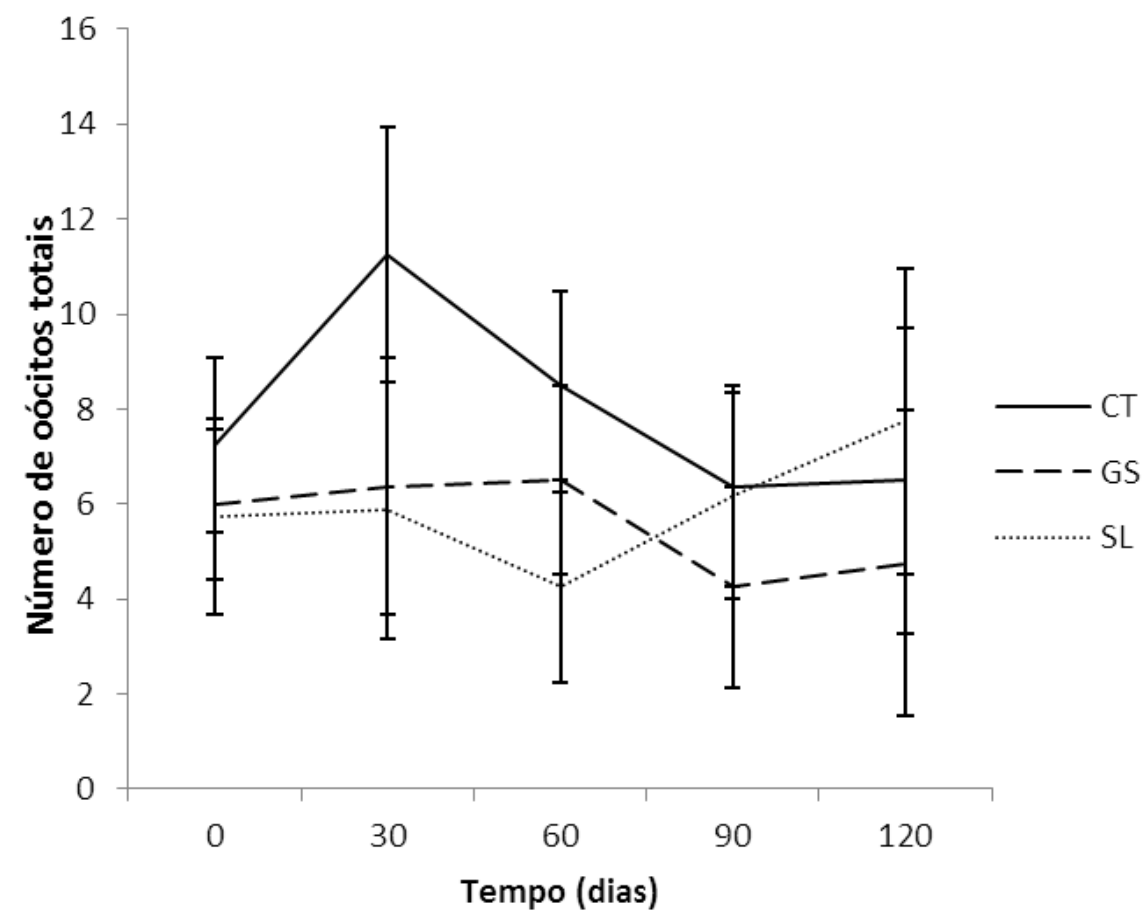


Figura 17 - Número de oócitos viaveis obtidos a partir das OPUs realizadas com os animais dos grupos experimentais: CT: Controle; GS: Grão de Soja; SL: Semente de Linhaça

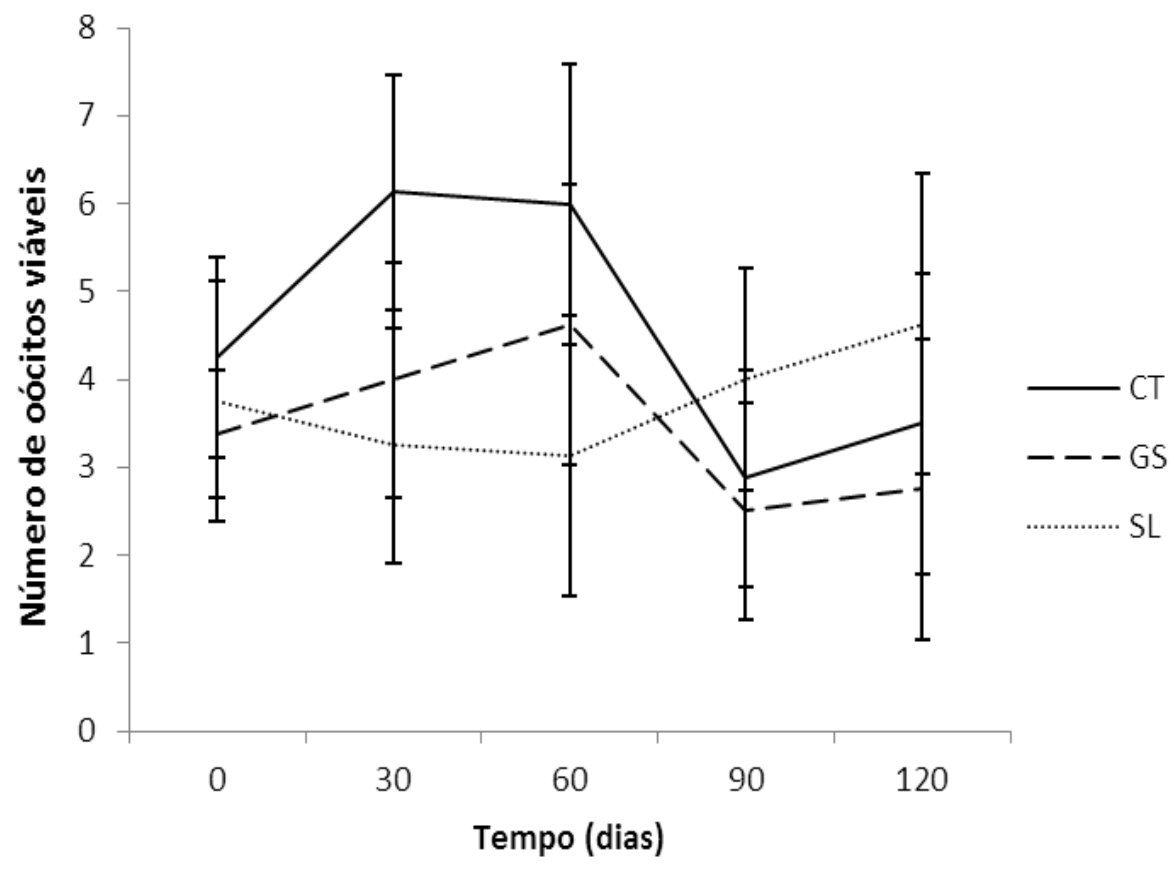

Figura 18 - Número de oócitos de Grau I obtidos a partir das OPUs realizadas com os animais dos grupos experimentais: CT: Controle; GS: Grão de Soja; SL: Semente de Linhaça

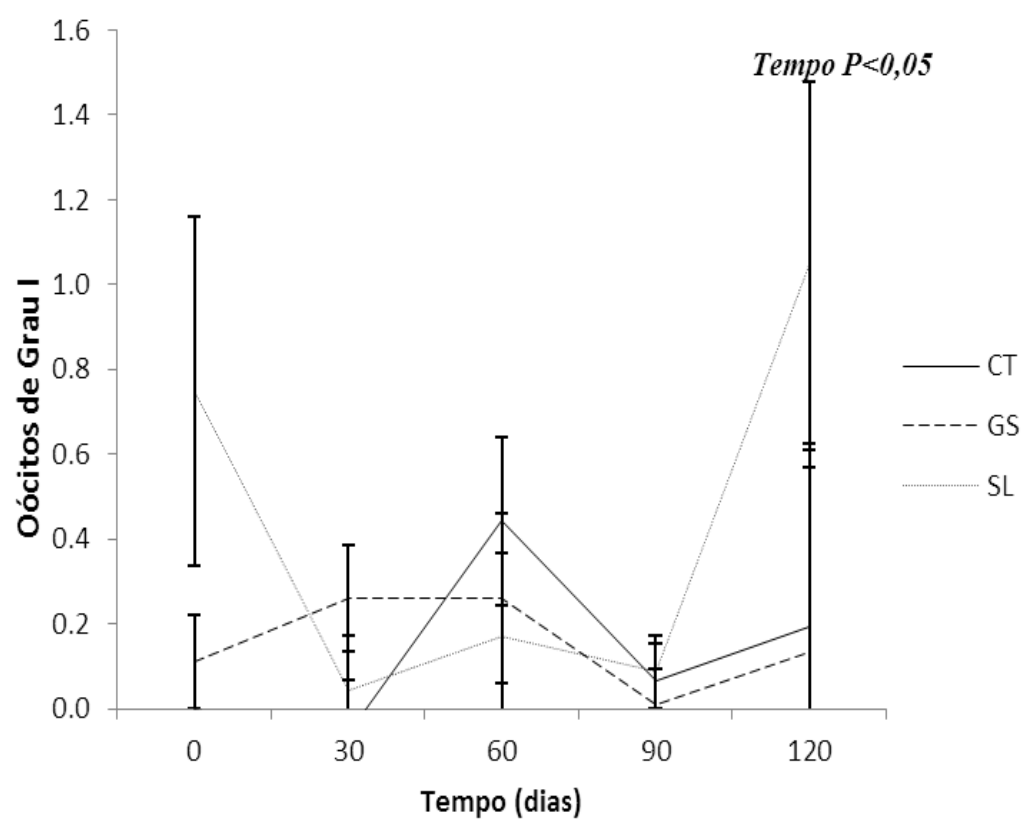


Figura 19 - Número de oócitos de Grau II obtidos a partir das OPUs realizadas com os animais dos grupos experimentais: CT: Controle; GS: Grão de Soja; SL: Semente de Linhaça

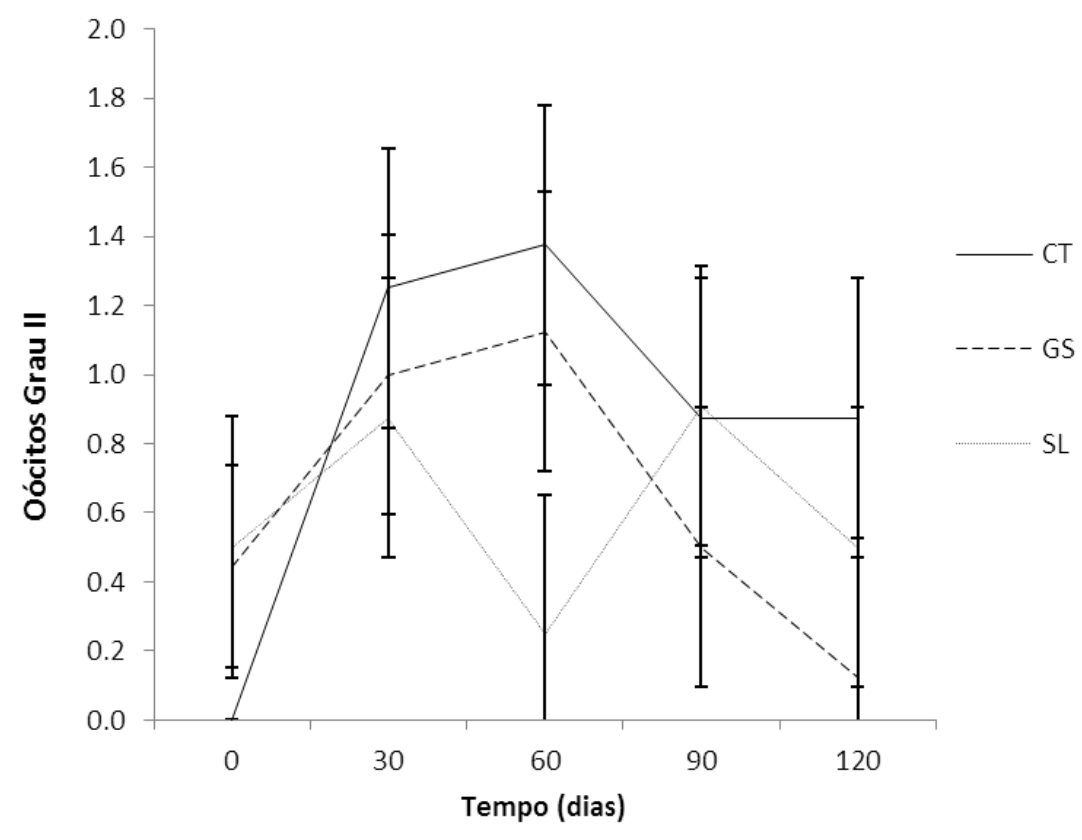

Figura 20 - Número de oócitos de Grau III obtidos a partir das OPUs realizadas com os animais dos grupos experimentais: CT: Controle; GS: Grão de Soja; SL: Semente de Linhaça

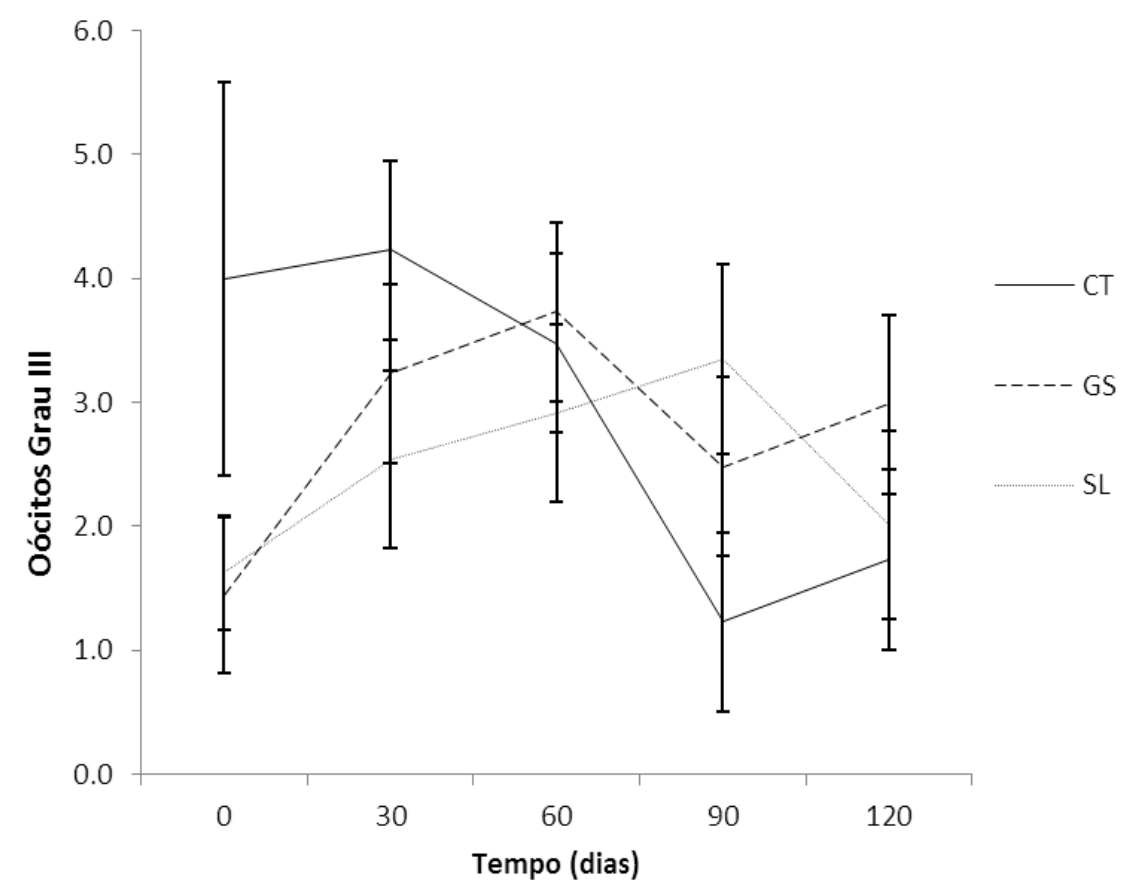


Figura 21 - Número de oócitos classificados em Grau I, Grau II e Grau III obtidos a partir das OPUs realizadas com os animais dos grupos experimentais: CT: Controle; GS: Grão de Soja; SL: Semente de Linhaça

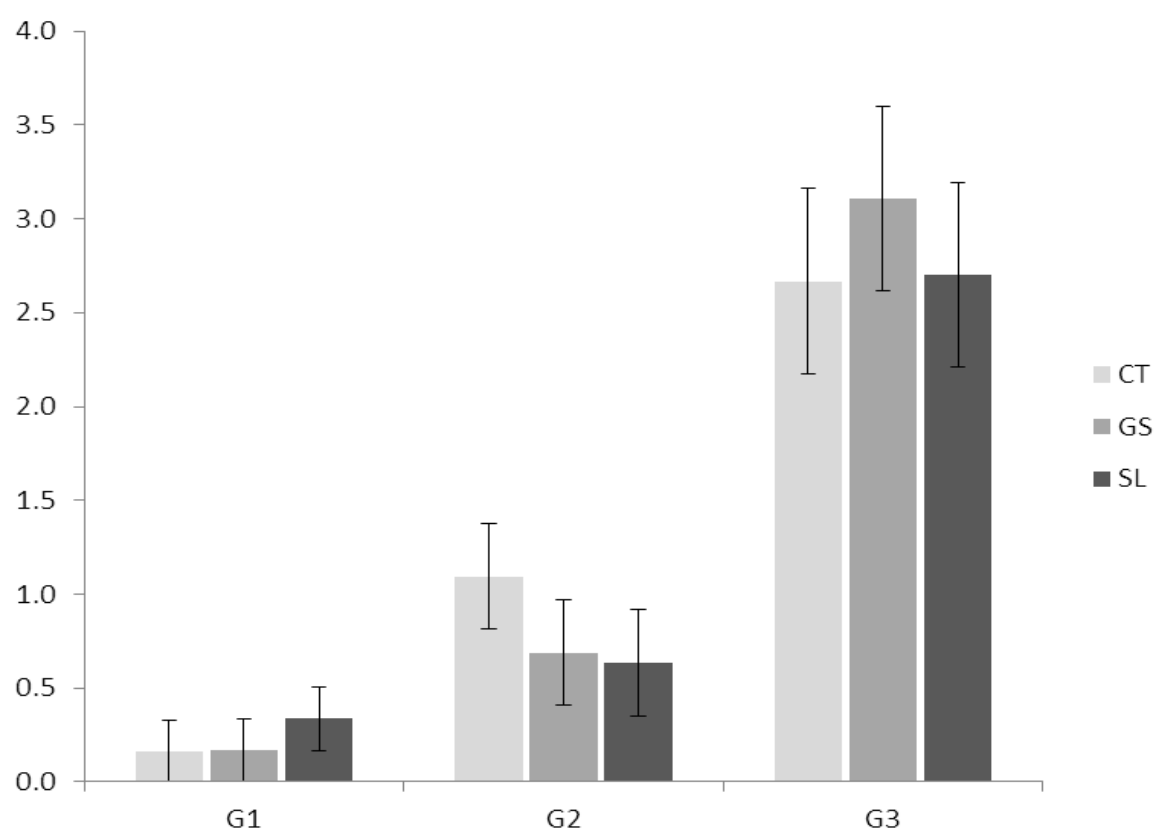

Figura 22 - Número de oócitos clivados obtidos a partir das OPUs realizadas com os animais dos grupos experimentais: CT: Controle; GS: Grão de Soja; SL: Semente de Linhaça

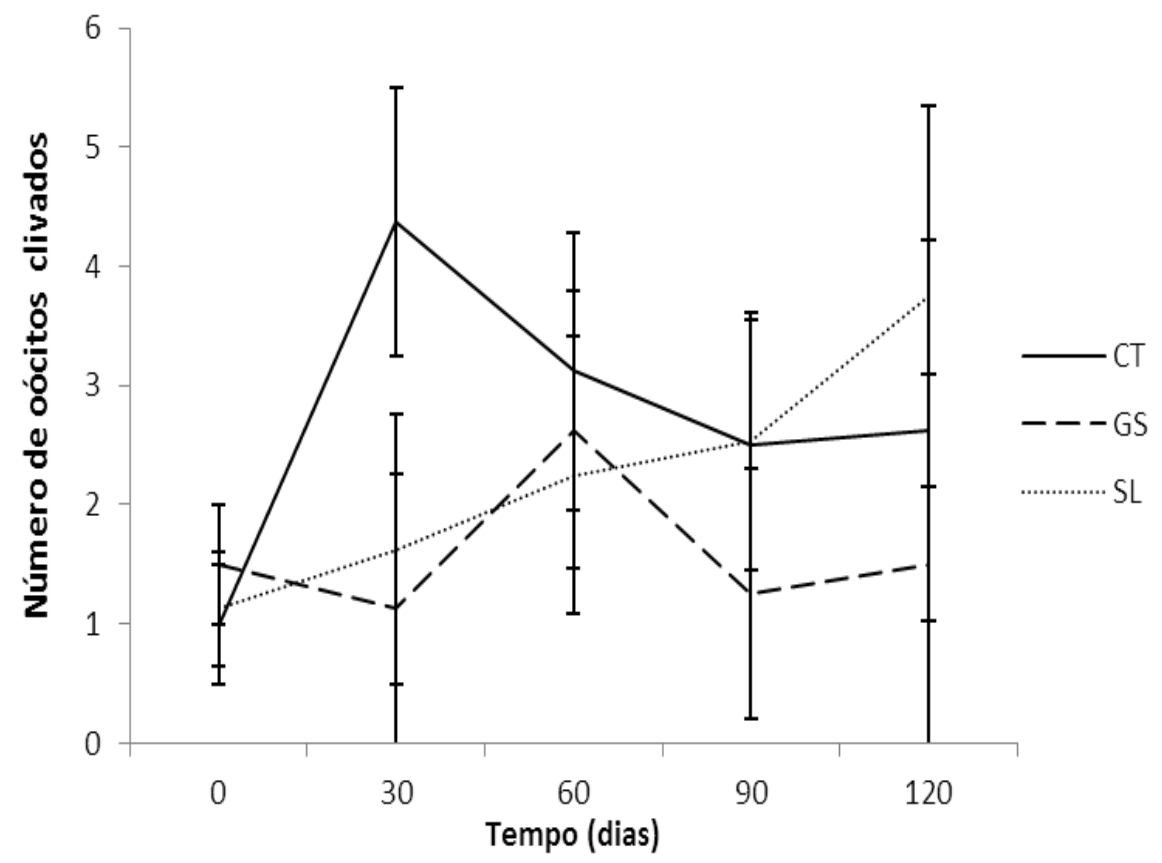


Figura 23 - Número de oócitos cultivados obtidos a partir das OPUs realizadas com os animais dos grupos experimentais: CT: Controle; GS: Grão de Soja; SL: Semente de Linhaça

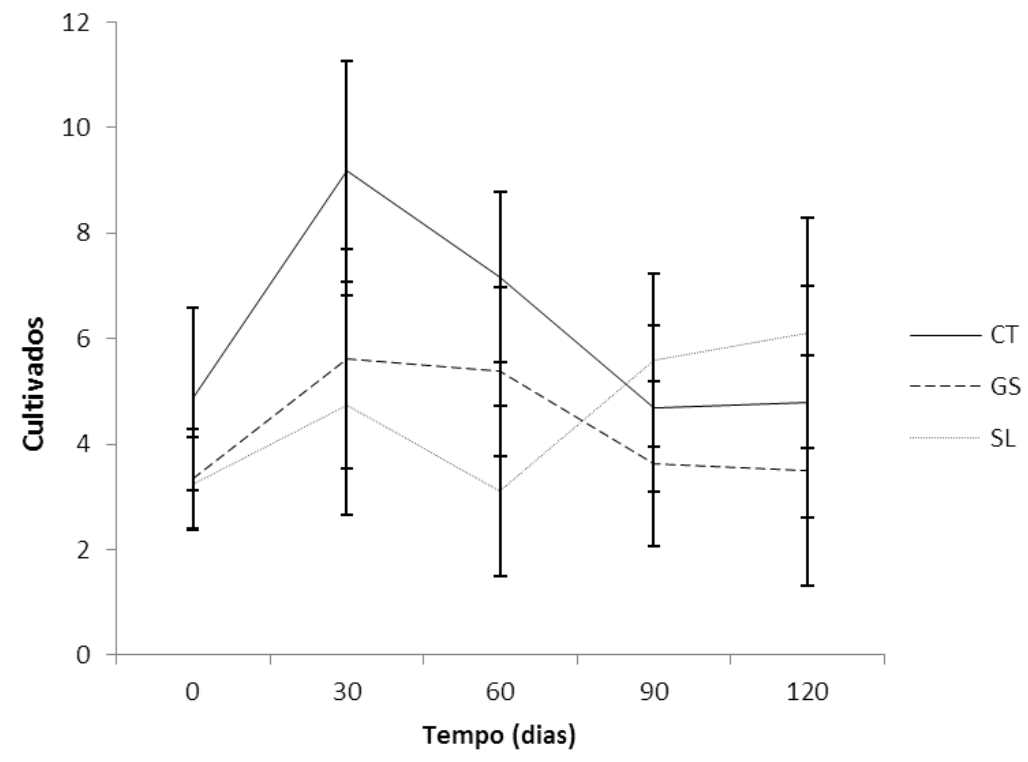

Figura 24- Número de embriões totais cultivados in vitro, a partir das OPUs realizadas com os animais dos grupos experimentais: CT: Controle; GS: Grão de Soja; SL: Semente de Linhaça

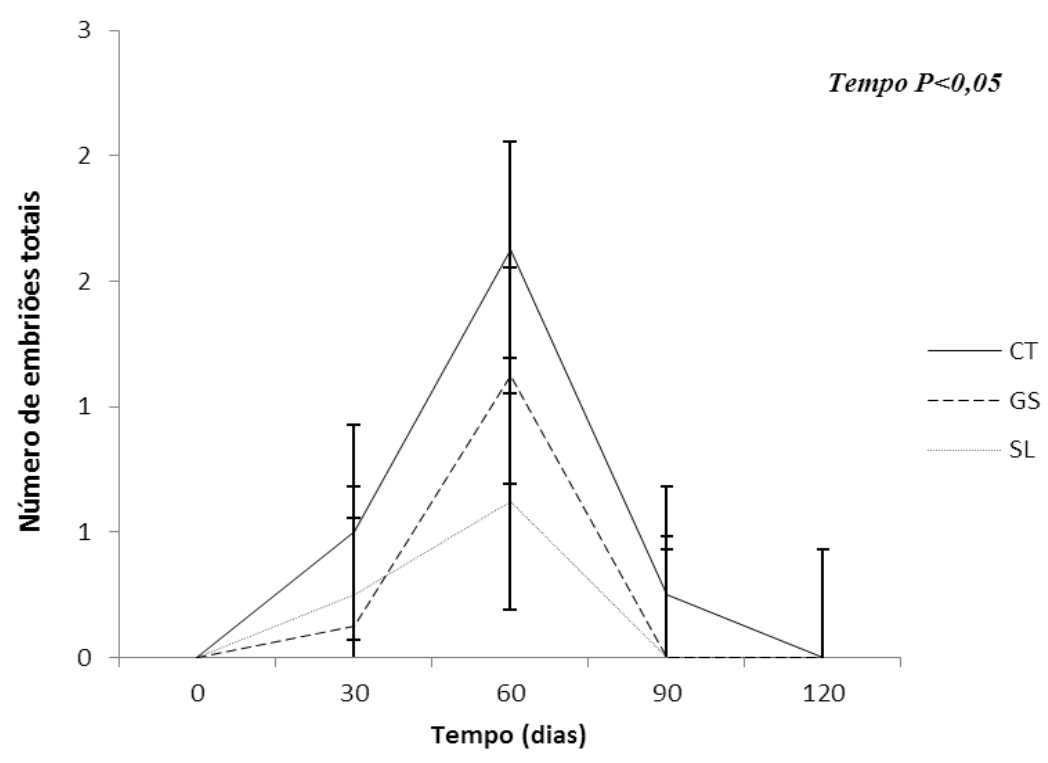


Figura 25 - Porcentagem de embriões obtidos a partir dos oócitos cultivados, provenientes das OPUs realizadas com os animais dos grupos experimentais: CT: Controle; GS: Grão de Soja; SL: Semente de Linhaça

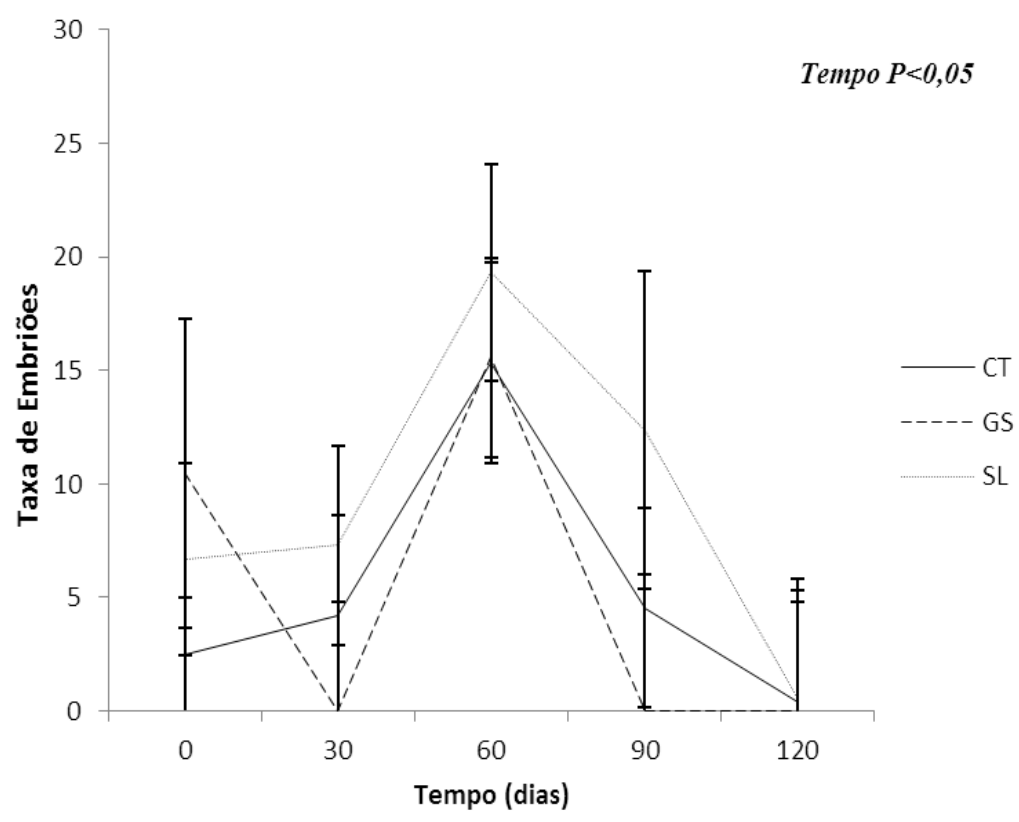

Figura 26 - Porcentagem de oócitos viáveis obtidos a partir dos oócitos totais, provenientes das OPUs realizadas com os animais dos grupos experimentais: CT: Controle; GS: Grão de Soja; SL: Semente de Linhaça

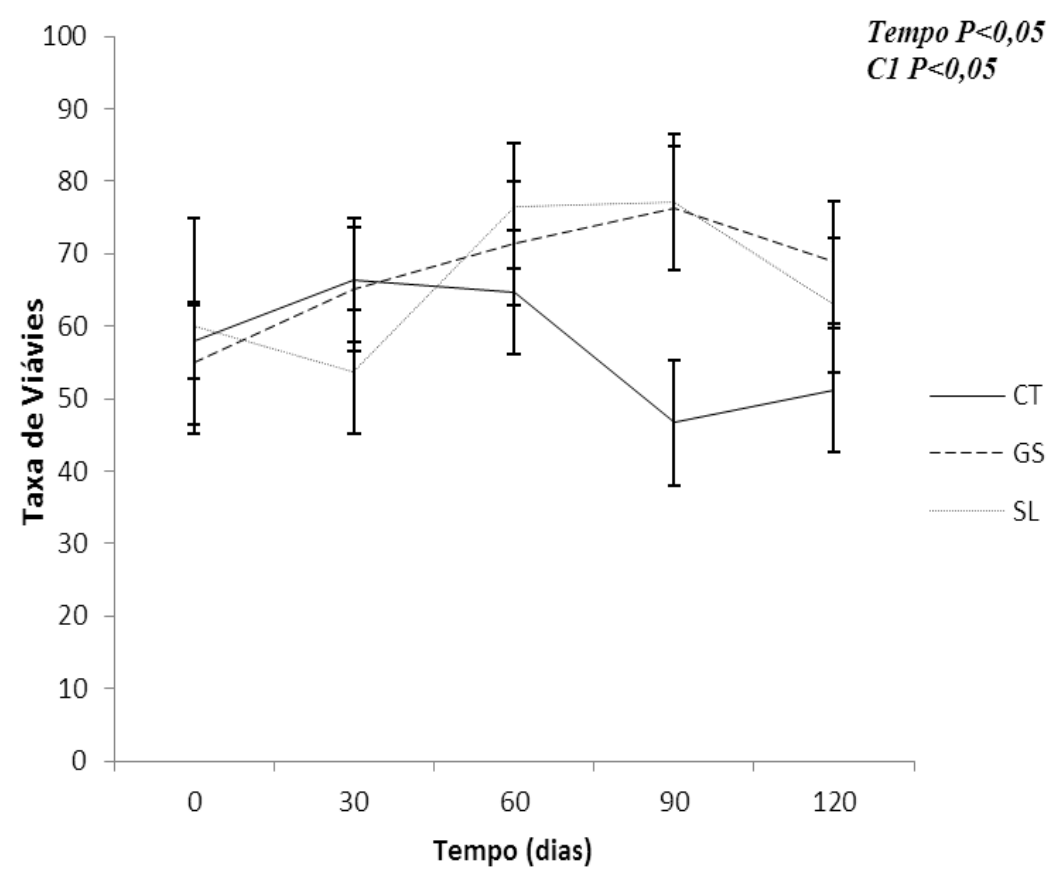


Figura 27 - Porcentagem de clivagem obtidos a partir dos oócitos totais, provenientes das OPUs realizadas com os animais dos grupos experimentais: CT: Controle; GS: Grão de Soja; SL: Semente de Linhaça

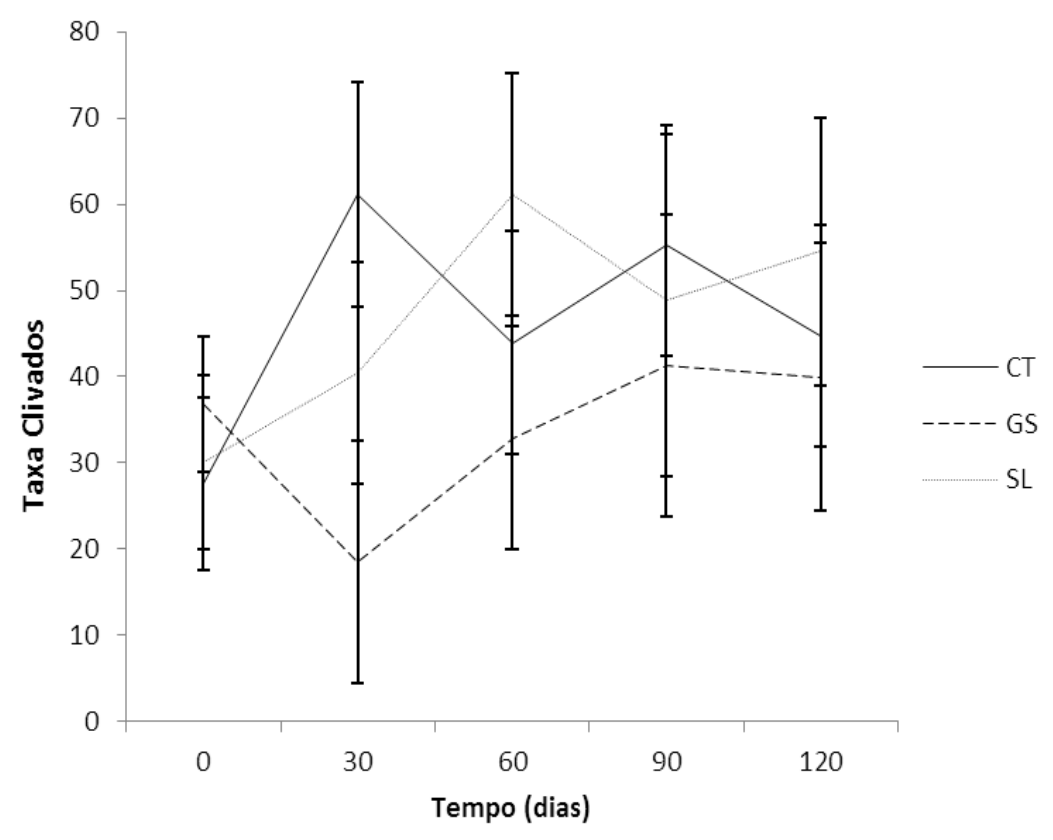

Relativamente, poucos trabalhos avaliaram o efeito dos ácidos graxos na produção e desenvolvimento de embriões produzidos in vivo (RYAN et al., 1992; KOJIMA et al., 1997; BADER et al., 2005; THANGAVELU et al., 2007; CHILDS et al., 2008A; PETIT et al., 2008; CERRI et al., 2009b). Além disso, ainda não há consenso se os ácidos graxos são mais importantes para o embrião em si ou para sua implantação (PETIT et al., 2008), pois podem reduzir a síntese ovariana e endometrial de PGF2 $\alpha$, auxiliar o embrião a produzir interferon $\mathrm{t}$, bem como alterar o ambiente do oviduto e do útero. Esses efeitos contribuem para o desenvolvimento embrionário, redução na morte embrionária e consequente estabelecimento da prenhez (BINELLI et al., 2001; MATTOS et al., 2004; CHILDS et al., 2008a). Nesse sentido, Thangavelu et al., (2007) demonstrou que a inclusão de AGPs na suplementação dietética teve efeito positivo no desenvolvimento embrionário. Vacas de leite alimentadas com sais de cálcio de ácido graxo linoleico apresentaram maiores porcentagens de embriões de alta qualidade $(73,5 \%$ vs $51,5 \%, \mathrm{P}=0,06)$ em relação aos animais que receberam sais de cálcio de óleo de palma (CERRI et al., 2009b). Da mesma forma, em novilhas de corte, o número de embriões degenerados foi reduzido para os animais que receberam dieta rica em AGPs n-3 em relação à dieta com ácido graxo saturado (CHILDS et al., 2008a).

Em trabalho onde foi avaliada a produção in vitro de embriões em grupos de novilhas taurinas recebendo dietas com alta ou baixa quantidade de energia, Nolan et al. (1998), 
encontrou maior quantidade de folículos aspirados nas dietas com alta energia, porém com menores taxas de clivagem e de blastocistos. Em outro estudo, novilhas taurinas alimentadas por um curto período de tempo com feno tiveram mais oócitos fecundados comparadas às demais recebendo silagem, sem diferenças, entretanto na produção in vitro de embriões (YAAKUB et al., 1999)

Em relação aos efeitos da suplementação sobre a qualidade oocitária e na produção de embriões, os dados da literatura são controversos, enquanto boa parte dos trabalhos indica que o aumento da quantidade de energia nas dietas para vacas e novilhas de corte e leite tem um efeito deletério sobre a competência oocitária e qualidade embrionária (ARMSTRONG et al., 2001, MCCAFFERY et al., 2000, NOLAN et al., 1998, FRERET et al, 2006), outros têm demonstrado efeitos benéficos da suplementação energética e com gorduras (FOULADINASHTA et al., 2007). Entretanto, a maioria dos trabalhos desconsidera os efeitos da condição corporal inicial dos animais, ou sobre condicionamento dos mesmos sobre a resposta de produção e qualidade de oócitos e embriões. Nesse sentido Adamiak et al. (2005) relatam que aumento do fornecimento de energia foi benéfico para a qualidade oocitária apenas nos animais com moderado ECC, e deletério para os animais com elevado ECC. Segundo Sartori (2002) ECC das novilhas foi moderado (4,2, em escala de 1-9) ao início dos tratamentos, o que não interferiu negativamente na qualidade oocitária e produção in vitro dos embriões. Os animais que receberam dietas com aumento de energia, tiveram tendência de melhores taxas de desenvolvimento embrionário in vitro, quando comparados aos tratamentos controle e com adição de gorduras, mostrando o efeito benéfico do flushing por curto período de tempo em novilhas Bos taurus indicus com moderado ECC no início da suplementação, como observado neste estudo. Fazendo uma breve analogia entre os estudos, podemos sugerir que realmente o ECC e/ou peso vivo pode influenciar a taxa de embriões viáveis, onde os animais selecionados para o grupo controle apresentaram maiores médias de peso vivo e ganho de peso diário em relação às dietas com adição de gordura como observado na tabela 6 , onde foi observado efeito significativo entre os tratamentos na avaliação de contraste, controle vs GS e SL apresentou menor valor 57.24 vs 70,40 e 67.57.

cultivo de embriões por $24 \mathrm{~h}$, aumentando também o número de células totais por blastocistos.

Nos resultados observados por Guardieiro (2008) não mostraram efeito da suplementação de lipídio na qualidade e quantidade de embriões de Nelore produzidos in vivo. Entretanto, em outros estudos, o número de embriões degenerados colhidos foi menor em novilhas submetidas à dieta com AGP n-3 (CHILDS et al., 2008b). Houve também um maior número total de embriões (KOJIMA et al., 1997) e embriões viáveis (KOJIMA et al., 
1997; Cerri et al., 2004) quando os animais receberam uma mistura de ácidos graxos oléico, LA e $\gamma$-LNA (KOJIMA et al., 1997) ou sais de cálcio de ácidos graxos LA e trans (CERRI et al., 2004). Thangavelu et al. (2007) observaram aumento no número de blastômeros em embriões de vacas alimentadas com AGP. Por outro lado, a adição de LA à dieta de vacas em lactação resultou em maior número de embriões degenerados e diminuição do número de embriões viáveis comparado àqueles provenientes de animais que receberam sais de cálcio de óleo de palma (PETIT et al., 2008).

Portanto relativamente, poucos trabalhos avaliaram o efeito dos ácidos graxos na produção e desenvolvimento de embriões produzidos in vivo (RYAN et al., 1992; KOJIMA et al., 1997; CERRI et al., 2004; BADER et al., 2005; THANGAVELU et al., 2007; CHILDS et al., 2008b; PETIT et al., 2008) e in vitro.

Além disso, não existe um consenso entre os resultados na literatura quando se refere ao perfil metabólico e qualidade e produção oócitaria e embrionária em novilhas alimentadas com fontes distintas de suplementação com ácidos graxos poli-insaturados ômega 3 e ômega 6. Apenas estudos confirmam que há uma grande relação entre nutrição e reprodução nesses animais. 


\section{CONCLUSÃO}

A suplementação prolongada com fontes de ácidos graxos ômega 3 e ômega 6 na alimentação de novilhas da raça Holandesa, independentemente da fonte utilizada, não apresenta melhorias consideráveis no desempenho reprodutivo dos animais, aumentando apenas a taxa de oócitos e/ou embriões viáveis, mas com influências sobre as concentrações de perfil metabólico. 


\section{REFERÊNCIAS}

ADAMIAK, S. J.; MACKIE, K.; WATT, R. G.; WEBB, R.; SINCLAIR, K. D. Impact of nutrition on oocyte quality: Cumulative effects of body composition and diet leading to hyperinsulinemia in cattle. Biology Reproduction, v. 73, p. 918-26, 2005.

ADAMS, G. P.; PIERSON, R. A. Bovine model for study of ovarian follicular dynamics in humans. Theriogenology, v. 43, p. 113-120, 1995.

ADAMS, G.P.; EVANS, A.C.O.; RAWLINGS, N.C. Follicular waves and circulating gonadotrophins in 8-month-old prepubertal heifers. Journal of Reproduction and Fertility, Cambridge, v. 100, p. 27- 33, 1994.

ADAMS, G.P.; MATTERI, R.L.; KASTELIC, J.P.; KO, J.C.H.; GINTHER, O.J. Association between surges of follicle-stimulating hormone and the emergence of follicular waves in heifers. Journal of Reproduction and Fertility, Cambridge, v. 94, p .177-188, 1992.

ALLAIN, C. C.; POON, L. S.; CHAN, C. S. G.; RICHMOND, W.; FU, P. C. Enzymatic determination of total serum cholesterol. Clinical chemistry, v. 20, p. 470-475, 1974.

ALVAREZ, P.; SPICER, L. J.; CHASE JR, C. C.; PAYTON, M. E.; HAMILTON, T. D.; STEWART, R. E.; HAMMOND, A. C.; OLSON,T. A.; WETTEMAN, R. P. Ovarian and endocrine characteristics during the estrous cycle in Angus, Brahman and Senepol cows in a subtropical environment. Journal Animal Science, v. 78, p. 1291-1302, 2000.

ANTONIOLLI, C. B. Desenvolvimento folicular, ondas foliculares e manipulação. 2002. 15 f. Seminário (Seminário apresentado na disciplina de Endocrinologia da Reprodução do Programa de Pós-graduação em Ciências Veterinárias) - Universidade Federal do Rio Grande do Sul, Porto Alegre. Disponivel em:

http://www6.ufrgs.br/bioquímica/posgrad/endocrino/foliculos.pdf. Acesso em: 04 nov. 2014.

ARMSTRONG, D. G.; MCEVOY, T. G.; BAXTER, G;. ROBINSON, J. J.; HOGG, C. O.; WOAD, K. J.; WEBB, R.; SINCLAIR, K. D. Effect of Dietary Energy and Protein on Bovine Follicular Dynamics and Embryo Production In Vitro: Associations with the Ovarian InsulinLike Growth Factor System. Biology of Reproduction, v. 64, p. 1624-1632, 2001.

ARMSTRONG, D. G.; GONG, J. G.; WEBB, R. Interactions between nutrition and ovarian activity in cattle: physiological, cellular, and molecular mechanisms. Reproduction Domestic Ruminants, v. 61, p. 403-414, 2003.

BACELAR, D.; MAX, M. C. ; PADILHA, L. C.; BARREIROS, T. R. R.; SENEDA, M. M. Incremento na obtenção de oócitos em novilhas Nelore (Bos taurus indicus) tratadas com progesterona injetável e benzoato de estradiol. Semina: Ciências Agrárias, Londrina, v. 31, n. 1, p. 163-172, jan./mar. 2010. 
BAILEY, T. L., MURPHY, J. M. 1999. Dairy heifer development and monitoring. In:

BALDRIDGE MG, STAHL RL, GERSTENBERGER SL, TRIPOLI V, HUTZ RJ. In utero and lactational exposure of Long-Evans rats to ammonium perchlorate (AP) disrupts ovarian follicle maturation. Reproduction Toxicology, v.19, p.155-161, 2004.

BAO, B.; GARVERICK, H.A. Expression of steroidogenic enzyme and gonadotropin receptor genes in bovine follicles during ovarian follicular waves: a review. Journal of Animal Science, Savoy, v. 76, p. 1903-1921, 1998.

BARCELLOS, J. O. J.; SILVA, M. D.; PRATES, E. R.; COSTA, E. C. Taxas de prenhez em novilhas de corte acasaladas aos 18 e 24 meses de idade. Arquivo Brasileiro de Medicina

Veterinária e Zootecnia, Belo Horizonte, v. 58, n. 6, p. 1168-1173, 2006.

BARROS, C. M.; NOGUEIRA, M. F. G. Embryo transfer in Bos indicus cattle. Theriogenology, v. 56, p. 1483-1496, 2001.

BASTOS, M. R.; MARTINS, A .C.; MELO, L. F.; CARRIJO, L. H. D.; RUMPF, R,; SARTORI, R. Efeito da condição corporal e da ingestão alimentar sobre a resposta superovulatoria e produção embrionária em novilhas Nelore. Abstract Acta Scientiae Veterinariae v. 35, (Supl. 3) b, 2007.

BASTOS, M. R.; RAMOS, A. R.; DRIESSEN, K; MARTINS, A .C.; RUMPF, R,; SARTORI, R. Efeito do flushing nutricional sobre a resposta superovulatoria em vacas mestiças. Abstract. Acta Scientiae Veterinariae v. 35, (Supl. 3) b, 2007.

BASTOS, M. R.; MATTOS, M. C. C.; MESCHIATTI, M. A. P.; SURJUS, R. S.; GUARDIEIRO, M. M.; MOURÃO, G. B.; PIRES, A. V.; PEDROSO, A. M.; SANTOS, F. A. P.; SARTORI, R. Ovarian function and circulating hormones in nonlactating Nelore versus Holstein cows. Acta Scientiae Veterinariae, v. 38, p. 776, 2010 (Resumo).

BEAM SW, BUTLER WR. Energy balance effects on follicular development and first ovulation in postpartum cows. Journal Reproduction Fertily Suppl, n.54, p.411.424, 1999.

BELLOWS RA, GRINGS EE, SIMMS DD, GEARY TW, BERGMAN JW. Effects of feeding supplemental fat during gestation to first-calf beef heifers. Prof Animal Scientist, v.17, p.81-89, 2001.

BERARDINELLI, J.G.; DAILEY, R.A.; BUTCHER, R.L.; INSKEEP, E.K. Source of progesterone prior to puberty in beef heifers. Journal of Animal Science, Savoy, v. 49, p. 1276-1280, 1979.

BERGFELT, D.R.; SEGO, L.H.; BEG, M.A.; GINTHER, O.J. Calculated follicle deviation using segmented regression for modeling diameter differences in cattle. Theriogenology, Gainesville v. 59, p. 1811-1825, 2003. 
BEZERRA, L.R. Desempenho e comportamento metabólico de cordeiros da raça Santa Inês alimentados com diferentes concentrações de Spirulina platensis diluída em leite de vaca. 2006. 41f. Dissertação (Mestrado em Sistemas Agrosilvopastoris no semi-árido) Centro de Saúde e Tecnologia Rural, Universidade Federal de Campina Grande, Campina Grande - PB.

BILBY, T. R.; JENKINS, T.; STAPLES, C. R.; THATCHER, W. W. Pregnancy, bovine somatotropin, and dietary n-3 fatty acids in lactating dairy cows: III. Fatty acid distribution. Journal of Dairy Science, v. 89, p. 3386-3399, 2006a.

BILBY, T.R.; BLOCK, J.; AMARAL, B.C.; SA FILHO, O.; SILVESTRE, F.T.; HANSEN, P.J.; STAPLES, C.R.; THATCHER, W.W. Effects of dietary unsaturated fatty acids on oocyte quality and follicular development in lactating dairy cows in summer. Journal of Dairy Science, v. 89, p. 3891-3903, 2006b.

BINELLI M. Estratégias anti-luteolíticas para a melhora da sobrevivência embrionária em bovinos. In: Simpósio sobre Controle Farmacológico do Ciclo Estral em Ruminantes, 1, 2000, São Paulo. Anais ... São Paulo: USP/FMVZ, 2000. p.99-114.

BINELLI, M.; THATCHER, W. W.; MATTOS, R..; BARUSELLI, P. S. Antiluteolytic strategies to improve fertility in cattle. Theriogenology, v. 56, p. 1452-1463, 2001.

BÓ, G.A.; ADAMS, G.P.; MAPLETOFT, R.J. Dinámica Folicular Ovariana en el Bovino. In: Simpósio sobre controle farmacológico do ciclo estral em ruminantes, 2000, São Paulo: Departamento de reprodução animal: Faculdade de Medicina Veterinaria e Zootecnia, Anais, p. $12-34,2000$.

BÓ, G. A.; BARUSELLI, P. S.; MARTINEZ, M. F. Pattern and manipulation of follicular development in Bos indicus cattle. Animal Reproduction Science, v. 78, p. 307-26, 2003.

BOKEN SL, STAPLES CR, SOLLENBERGER LE, JENKINS TC, THATCHER WW. Effect of grazing and fat supplementation on production and reproduction of Holstein cows. Journal Dairy Science, v.88, p.4258-4272, 2005.

BOLAND MP, LONERGAN P, O'CALLAGHAN D. Effect of nutrition on endocrine parameters, ovarian physiology, and oocyte and embryo development. Theriogenology, v.55, p.1323-1340, 2001.

BOLAND, M. P.; LONERGAN, P.; O'CALLAGHANZ, D. Effect of nutrition on endocrine parameters, ovarian physiology, and oocyte and embryo development. Theriogenology, v. 55, p. 1323-1340, 2001. Brasileira de Zootecnia. v. 33, n. 1, p. 103-111, 2004.

BRISTOL-GOULD S, WOODRUFF TK. Folliculogenesis in the domestic cat (Felis catus). Theriogenology, v.1, p. 5-13, 2006. 
BRODERICK GA, CLAYTON MK. A statistical evaluation of animal and nutritional factors influencing concentrations of milk urea nitrogen. Jouranl Dairy Science, v.80, p.2964-2971, 1997.

BUTLER, W. R. Effect of protein nutrition on ovarian and uterine physiology in dairy cattle. Journal Dairy Science, v. 81, p. 2533-2539, 1998.

CAMPBELL, B. K.; SCARAMUZZI, R. J.; WEBB, R. Control of antral follicle development and selection in sheep and cattle. Reproduction in Domestic Ruminants III. Journal Reproduction Fertility, v. 49, p.335-350, 1995. Supplemetum 49.

CARVALHO, B.C. Efeito da base genética materna, sistema de suplementação durante a recria e estação de parição sobre variáveis produtivas e reprodutivas de fêmeas primíparas holandês-zebu. 2005. 98f. Dissertação (Mestrado em Zootecnia) - Escola de Veterinária, Universidade Federal de Minas Gerais, Belo Horizonte, 2005.

CARVALHO, J. B. P.; CARVALHO, N. A. T.; REIS, E. L.; NICHI, M.; SOUZA, A. H.; BARUSELLI, P. S. Effect of early luteolysis in progesterone-based timed AI protocols in Bos indicus, Bos indicus x Bos taurus, and Bos taurus heifers. Theriogenology, v. 69, p. 167-175, 2008.

CASTILHO, C. Desenvolvimento folicular e sincronização da ovulação em novilhas da raça Girolando. Dissertação (Mestrado), 94 p., Unesp, Botucatu, 1999.

CASTILHO C.; GAMBINI, A.L.G.; FERNANDES, P.; TRINCA, L.A.; TEIXEIRA, A.B.; BARROS, C.M. Synchronization of ovulation in crossbred dairy heifers using gonadotropinreleasing hormone agonist, prostaglandin F2 á and human chorionic ganadotropin or estradiol benzoate. Brazilian Journal of Medical and Biological Research, v. 33, p. 91-101, 2000.

CERRI, R.L.A.; BRUNO, R.G.S.; CHEBEL, R.C.; GALVAO, K.N.; RUTGLIANO, H.;CERRI, R.L.A.; JUCHEM, S.O.; CHEBEL, R.C.; RUTIGLIANO, H.; BRUNO, R.G.S.; GALVÃO, K.N.; THATCHER, W.W.; SANTOS, J.E.P. Effect of fat source differing in fatty acid profile on metabolic parameters, fertilization, and embryo quality in highproducing dairy cows. Journal of Dairy Science, v.92, p.1520-1531, 2009.

CHILDS, S.; HENNESSY, A. A.; SREENAN, J. M.; WATHES, D. C.; CHENG, Z.; STANTON, C.; DISKIN, M. G.; KENNY, D. A. Effect of level of dietary n-3 polyunsaturated fatty acid supplementation on systemic and tissue fatty acid concentrations and on selected reproductive variables in cattle. Theriogenology, v. 70, p. 595- 611, 2008.

CHURCH, D.C.; POND, W.G. Bases Cientifi cas para la Nutricion y Alimentacion de los Animales Domesticos. Zaragoza : Acribia,1977. 462p. cows. Journal Dairy Science, v.87, n.1, p.297, 2004. Abstract.

DAY, M.L. Effects of restriction of dietary energy intake during the prepubertal period on secretion of luteinizing hormone and responsiviness of the pituitary to luteinizing hormonereleasing hormone in heifers. Journal of Animal Science, v.62, p.1641-1648,1986. 
DIRKSEN, G.; BREITNER, W. New quick-test for semi quantitative determinations of betahydroxybutyric acid in bovine milk. Journal Veterinary Medical Animal Physiology

Pathology Clinical Medical, v. 40, p. 779-784, 1993.

DISKIN, M. G.; MACKEY, D. R.; ROCHE, J. F.; SREENAN, J. M. Effects of nutrition and metabolic status on circulation hormones and ovarian follicle development in cattle. Animal Reproduction Science, v. 78, p. 345-370, 2003.

DISKIN, M.G.; MORRIS, D.G. Embryonic and early foetal losses in cattle and other ruminants. Reproduction in Domestic Animals, v.43(Suppl. 2), p.260-267, 2008.

DOWNIE, J, G.; GELMAN, A. L. The relationship between changes in body weight, plasma glucose and fertility in beef cows. Veterinary Record, London, v. 99, p. 210-212, 1976.

DOWNING, J.A.; SCARAMUZI, R.J. Nutrients effect on ovulation rate, ovarian function and secretion of gonadotrophic and metabolic hormones in sheep. Journal of Reproduction and Fertility, v. 43, p.209-227, 1991.

DROST, D. V. M. M. Training Manual For Embryo Transfer in Cattle, Flórida: College of Veterinary Medicine, University of Flórida, 1995, 59 p.

DUNE, L.D.; DISKIN, M. G.; BOLAND, M. P.; O'FARRELL, K. J.; SRREMAN, J. M. The effect of pre ande post insemination plane of nutrition on embryo survival in beef heifers.

Animal Science, v. 69, p. 411-417, 1999.

DUNNE, L. D.; DISKIN, M. G.; BOLAND, M. P.; O’FARRELL, K. J.; SREENAN, J. M. Nutrition and embryo survival in cattle. Journal Agriculture Food Research, v. 36, p. 95, 1997.

EARLEYWIN, T. J. Raw soybeans in dairy rations. In: Proc. Annual and Semiannual meetings of the American Feed Industry Council. p 41. Kansas City, MO and San Antonio, 1989.

ELROD, C.C.; BUTLER, W, R. Reduction of fertility and alteration of uterine $\mathrm{pH}$ in heifers fed excess ruminally degradable protein. Journal Animal Science, v.71, p.694-701, 1993.

ELROD, C.C.; VAN AMBURGH, W.R.; BUTLER, W.R. Alterations of pH in response to increased dietary protein in cattle are unique to the uterus. Journal Animal Science, v.71, p.702-706, 1993.

ENSMINGER, M.E.; OLENTINE, C.G. Feeds \& Nutrition. Clovis, CA: Ensminger Publ., 1978. 1417p. p.701-742.

EVANS, A.C.O.; CURRIE, W.D.; RAWLINGS, N.C. Effects of naloxone on circulating gonadotrophin concentrations in prepubertal heifers. Journal of Reproduction and Fertility, Cambridge, v. 96, p. 847-855, 1992. 
EVANS, A. C. O.; ADAMS, G. P.; RAWLINGS, N. C. Endocrine and ovarian follicular changes leading up to the first ovulation in prepubertal heifers. Journal of Reproduction and Fertility, v. 100, p. 187-194, 1994.

EVANS, A.C.O.; ADAMS, G.P.; RAWLINGS, N.C. Follicular and hormonal development in prepubertal heifers from 2 to 36 weeks of age. Journal of Reproduction and Fertility, Cambridge, v. 102, p. 463-470, 1994.

EVANS, A.C.O; FORTUNE, J.E. Selection of the dominant follicle in cattle occurs in the absence of differences in the expression of messenger ribonucleic acid for ganodotropin receptors. Endocrinology, v.138, n.7, p.2963-2971, 1997.

EZZO OH, HEGAZY MA. Effect of dietary fat on ovarian and metabolic response of heifers suffering from ovarian inactivity. Veterinary Medicine Journal, v.47, p.45-57, 1999.

FARNWORTH PG. Gonadotrophin secretion revised - how many ways can FSH leavea gonadotroph. Journal Endocrinol, v.145, p.387-395, 1995.

FARNWORTH, P.G. Gonadotrophin secretion revised - how many ways can FSH leave a gonadotroph. Journal Endocrinologyc, v.145, p.387-395, 1995

FERGUSON JD, GALLIGAN DT, BLANCHARD T, REEVES M. Serum urea nitrogen and conception rate: the usefulness of test information. Jouranl Dairy Science v.76, p.3742-3746, 1993.

FERGUSON, E. M.; SLEVIN, J.; EDAWRDS, S. A.; HUNTER, M. G.; ASHWORTH, C. $\mathrm{J}$. Effect of alterations in the quantity and composition of the pre-mating diet on embryo survival and foetal growth in the pig. Animal Reproduction Science, v. 96, p. 89-103, 2006.

FERREIRA, A. M.; VIANA, J. H. M.; SÁ, W. F. Restrição alimentar e atividade ovariana luteal cíclica pós-parto em vacas Girolanda. Pesquisa Agropeuária Brasileira, v. 35, p. 2521-2528, 2000.

FERREIRA, J. L.; TONIOLLI, R.; DUARTE, A. B. G. Ação do fator de crescimento semelhante à insulina I (IGF-I) e de suas proteínas ligadoras(IGFBPs) no desenvolvimento folicular de bovinos. Revista Brasileira de Reprodução Animal, v. 26, n. 4, p. 306-311, 2002.

FERREIRA, E. M.; VIREQUE, A. A.; ADONA, P. R.; MEIRELLES, F. V.; FERRIANI, R. A.; NAVARRO, P. A. A. S. Cytoplasmic maturation of bovine oocytes: structural and biochemical modifications and acquisition of developmental competence. Theriogenology, v. 71, p. 836-848, 2010.

FERREIRA, R. M.; AYRES, H.; FERRAZ, M. L.; ARAUJO, A. B.; CHIARATTI, M. R.; SA FILHO, M. F.; CALOMENI, G.; RODRIGUES, C. A.; WATANABE, Y. F.; VIREQUE, A. 
A.; BARUSELLI, P. S. Ovum pick up and in vitro embryo production during the summer: differences between holstein heifers, high producing hostein cows in peak lactation and repeat-breeder hostein cows. Reproduction Fertility and Development, v. 22, p. 290, 2010.

FIALHO MPF, OLIVEIRA V. Influência da suplementação com gordura no pós-parto de vacas. Artigo de revisão de literatura vencedor do I prêmio MACAL de incentivo a pesquisa em bovinocultura de corte. 2005. Disponível em:

http://www.macal.com.br/uploads/1364850134.pdf. Acessado em: 26 nov. 2007.

FIGUEIREDO, D. M.; PAULINO, M. F.; DETMANN, E.; SOUZA, M. G.; COUTO, V. R. M.; SALES, M. F. L. Estratégias de suplementação para antecipação da id Estratégias de suplementação para antecipação da idade à puberdade para novilhas de corte em pastagem tropical. Acta Scietiarum Animal Science. Maringá, v. 30, n. 4, p. 415-423, 2008.

FIGUEIREDO, R. A.; BARROS, C.M.; PINHEIRO, O.L.; SOLER, J.M.P. Ovarian Follicular Dnamics in Nelore Breed (Bos indicus) Cattle. Theriogenology, v. 47, p. 1484-1505, 1997.

FORTUNE, J.E.; RIVERA, G.M.; YANG, M.Y.. Follicular development: the role of the follicular microenvironment in selection of the dominant follicle. Animal Reproduction Science, Savoy, v. 82-83, p. 109-126, 2004.

FOULADI-NASHTA, A. A.; GUTIERREZ, C. G.; GONG, J. G.; GARNSWORTHY, P. C.; WEBB, R. Impact of dietary fatty acids on oocyte quality and development in lactating dairy cows. Biology of Reproduction, v. 77, p. 9-17, 2007.

FRASER, C. M. Manual Merrck de Veterinária. São Paulo, Roca, 1991.

FRENEAU, G. E.; CRUZ, G. C.; SILVA, J. C. C.; RODRIGUES, M. K. F.; MENEZES, S. M. Caracterização de eventos reprodutivos da fase puberal em novilhas F1 Holandês-Jersey. In: CONBRAVET, 35. Gramado, 2008. Anais... v. 1. p. 1-5.

FRERETE, S.; GRIMARD, B. PONTER, A. A. Reduction of body-wheight gain enhances in vitro embryo production in overfed superovulated dairy heifers. Reproduction. v. 31, p. 783794, 2006.

FUNSTON, R.N. Fat supplementation and reproduction in beef females. Journal of Animal Science, v.82, p.154-161, 2004.

GALINA, C.; ARTHUR, G. Review on Cattle Reproduction in the Tropics. Part 4. Oestrus Cycles. Animal Breed. Abstratc, v. 58, p. 697-707, 1990.

GAMBINI, A.L.G.; MOREIRA, M.B.P.; CASTILHO, C.; BARROS, C.M. Dinâmica follicular e sincronização da ovulação em vacas da raça Gir. Revista Brasileira Reprodução Animal, v. 22, p. 201-210, 1999.

GANDRA, J. R. Fontes de ácidos graxos ômega 3 e ômega 6 em dietas de vacas leiteiras no período de transição e inicio de lactação. 2012, 170f. Tese (Doutorado em Ciências) - 
Faculdade de Medicina Veterinária e Zootecnia, Universidade de São Paulo, Pirassununga, 2012.

GARCIA, A.; SALAHEDDINE, M. Effects of repeated ultrasound-guided transvaginal follicular aspiration on bovine oocyte recovery and subsequent follicular development. Theriogenology, v. 50, n. 4, p. 575-585, setembro de 1998.

GARDNER, R.W., SMITH, L.W., PARK, R.L. 1988. Feeding and management of dairy heifers for optimal lifetime productivity. Journal Dairy Science ,71:996.

GARDNER, D. K.; LANE, M. Amino acids and ammonia regulate mouse embryo development in culture. Biologyc Reproduction, v. 48, p. 377-385, 1993.

GARNSWORTHY PC, LOCK A, MANN GE, SINCLAIR KD, WEBB R. Nutrition, metabolism, and fertility in dairy cows: 2 . dietary fatty acids and ovarian function. Journal Dairy Science, v.91, p.3824-3833, 2008.

GILL, G.S.; ALLAIRE, F.R. 1976. Relationship of age of first calving, days open, days dry, and herdlife to a profit function for dairy cattle. Journal Dairy Science, 59:1131.

GIMENES, L. U.; FANTINATO NETO, P.; ARANGO, J. S. P.; AYRES, H.; BARUSELLI, P. S. Follicular dynamics of Bos indicus, Bos taurus and Bubalus bubalis heifers treated with norgestomet ear implant associated or not to injectable progesterone. Animal Reproduction, v. 6, p. 256, 2009 (resumo).

GINTHER, O.J.; KNOPF, L.; KASTELIC, J.P. Temporal associations among ovarian events in cattle during oestrous cycles with two and three follicular waves. Journal Reproduct Fertility, v. 887, p. 223-30, 1989.

GINTHER, O.J.; BERFELT, D.R.; BEG, M.A.; KOT, K. Follicle selection in monovular species. Biologyc Reproduction, v. 65, p. 638-647, 2001.

GINTHER, O.J.; BEG, M.A.; DONADEU, F.X.; BERGFELT, D.R.Mechanism of follicle deviation in monovular farm species. Animal Reproduction Sciences, Savoy, v. 78, p.239257, 2003a.

GLISTER, C.; TANNETTA, D.S.; GROOME, N.P.;KNIGHT, P.G. Interactions between follicle-stimulating hormone and growth factors in modulating secretion of steroids and inhibin-related peptides by nonluteinized bovine granulosa cells. Biology of Reproduction, Madison, v. 65, p. 1020-1028, 2001.

GODOY, M.M.; ALVES, J.B.; MONTEIRO, A.L.G. Parâmetros reprodutivo e metabólico de vacas da raça Guzerá suplementadas no pré e pós-parto. Revista da Sociedade

GOMES, S. T., NASCIF, C., MAROTA, W. B. 2001. Criar ou comprar novilhas leiteiras?. In: Custos da Produção de Leite. UFV, 2001, p.76. 
GONG, J. G.; LEE, W. J.; GARNSWORTHY, P. C.; WEBB, R. Effect of dietary-induced increases in circulating insulin concentrations during the early postpartum period on reproductive function in dairy cows. Reproduction, v. 123, p. 419-427, 2002a.

GONG, J. G.; ARMSTRONG, D. G.; BAXTER, G.; HOGG, C. O.; GRANSWORTHY, P. C.; WEBB, R. The effect of dietary intake on superovulatory response to FSH in heifers. Theriogenology, v. 57, p. 1591-1602, 2002b.

GONZALEZ, F. D.; TORRES, C. A.; VETROMILA, M. A. Efeito da condição corporal em novilhas mestiças sobre a fertilidade, e os níveis sanguíneos de glicose, albumina e progesterona pós-serviço. Revista Brasileira de Zootecnia, v. 22, p. 439-444, 1993.

GOSDEN RG, BOLAND NI, SPEARS N, MURRAY AA, CHAPMAN M, WADE JC, ZOHDY NI. The biology and technology of follicular oocyte development in vitro. Reproductive Medicine Review, v.2, p.29-152, 1993.

GRUMMER RR, CARROLL DJ. A review of lipoprotein cholesterol metabolism: importance to ovarian function, Journal of Animal Science, v.66, p.3160-3173, 1988.

GRUMMER RR, CARROLL DJ. Effects of dietary fat on metabolic disorders and reproductive of dairy cattle. Journal of Animal Science v.69, p.3838-3852, 1991.

GUINTHER, O.J.; KONOPF, L.; KASTELIC, J.P. Temporal associations among ovarian evenst in cattle during oestrous cycles with two and three follicular waves. Journal of Reproduction and Fertily, v. 87, p. 223-230, 1989.

GUTIERREZ, C. G.; CAMPBELL, B. K.; WEBB, R. Development of a long-term bovine granulosa cell culture system: induction and maintenance of estradiol production, response to follicle stimulating hormone and morphological characteristics. Biology of Reproduction, v. 56, p. 608-616, 1997a.

GUTIERREZ, C. G.; OLDHAM, J.; BRAMLEY, T. A.; GONG, J. G.; CAMPBELL, B. K.; WEBB, $R$. The recruitment of ovarian follicles is enhanced by increased dietary intake in heifers. Journal of Animal Science, v. 75, p. 1876-1884, 1997b.

GUTIERREZ, C. G.; RALPH, J. H.; TELFER, E. E.; WILMUT, I.; WEBB, R. Growth and antrum formation of bovine antral follicles in long-term culture in vitro. Biology of Reproduction, v. 62, p. 1322-1328, 2000.

HAFEZ, E.S.E. Reprodução Animal. Philadelphia: Lea \& Fabiger, 1993, 582p.

HAFEZ, E.S.E. Reprodução Animal 6 Edição. Editora Manole, São Paulo, 1995.

HAFEZ, E. S. E; HAFEZ, B. Ciclos Reprodutivos. In: HAFEZ, E. S. E; HAFEZ, B. Reprodução Animal, 7. ed. Barueri, SP: Ed Manole, 2004. cap. 4, p. 55-67. 
HAIDA, K. S.; DIAZ GONZALES, F. H.; PARZIANELLO, N. Estudo de perfil metabólico leiteiro do Oeste do Paraná. Semina: Ciência Agronômica, Londrina, v. 17, n. 1, p. 72-76, mar 1996.

HALLETT, C. J.; COOK, J. G. H. Reduced nicotinamide adenine dinucleotide-coupled reaction for emergency blood urea estimation. Clinica Chimica Acta, v. 35, p. 33-37, 1971.

HARESIGN, W. The influence of nutrition on reproduction in the ewe. Animal Reproduction Science, v.32, p.197-202, 1981.

HIGGINBOTHAM GE, HUBER JT, WALLENTINE MV, JOHNSTON NP, ANDRUS D. Influence of protein percentage and degradability on performance of lactating cows during moderate temperature. Jouranl Dairy Science v.72, p.1818-1823, 1989.

HOMA, S. T.; BROWN, C. A. Changes in linoleic acid during folicular development and inhibition of spontaneous breakdown of germinal vesicles in cumulus-free bovine oocytes. Journal of Reproduction and Fertility, v. 94, p. 153-160, 1992.

HONARAMOOZ, A.; COOK, S.J.; BEARD, A.P.; BARTLEWSKI, P.M.; RAWLINGS, N.C.. Nitric oxide regulation of gonadotrophin secretion in prepubertal heifers. Journal of Neuroendocrinology, Oxford, v. 11, p. 667-676, 1999.

HORTA, A.E.M.; SANTOS, I.C.; MARQUES, M.R.; REIS, A.; SILVA PEREIRA, M.; MARQUES, C.C. Biopsied and vitrified bovine embryos viability is improved by trans 10 , cis12 conjugated linoleic acid supplementation during in vitro embryo culture. Animal Reproduction Science, v.106, p.322-332, 2008.

HOWARD, J. L.; SMITH, R. A. (4º Ed). Current Veterinary Therapy. p.86-93, 1999.

HUTT KJ, MCLAUGHLIN EA, HOLLAND MK. Kit ligand and c-Kit have diverse roles during mammalian oogenesis and folliculogenesis. Molecular Human Reproduction, v.12, p.61-69, 2006.

KAKUDA, D. K.; MACLEOD, C. L. Na(+)-independent transport (uniport) of amino acids and glucose in mammalian cells. The Journal of Experimental Biology, v. 196, p. 93-108, 1994.

KANEKO, J. J. Clinical Biochemistry os Domestic Animals. 4 Ediação. New York: Academic Press. 1989.

KAPPEL, L. C.; INGRAHAM, R. H.; MORGAN, E. B. Relationship between fertilitiy and blood glucose and cholesterol concentrations in Holstein cows. Animal Jouranl Veterinary Research. v. 45, p. 2607-2612, 1984.

KEISLER, D. H.; LUCY, M. C. Perception and interpretation of the effects of undernutrition on reproduction. Journal of Animal Science, v. 74, p. 1-17, 1996. 
KIM, J. Y.; KINOSHIT, M.; OHNISHI, M.; FUKUI, Y. Lipid and fatty acid analysis of fresh and frozen-thawed immature an in vitro matured bovine oocytes. Reproduction, v. 122, p. 131-138, 2001.

KIM, J. Y.; KINOSHITA, M.; OHNISHI, M.; FUKUI, Y. Lipid and fatty acid analysis of fresh and frozen-thawed immature and in vitro matured bovine oocytes. Reproduction, v.122, p.131-138, 2001.

KINDER, J.E. Endocrine regulation of puberty in cows and ewes. Journal of Reproduction and Fertility, v.34, p.167-186, 1987.

KINDER, J.E.; BERGFELD, E.G.M.; WEHRMAN, M.E. Endocrine basis for puberty in heifers and ewes. Journal Reproduction Fertily Suppl., n.49, p.393-407, 1995.

KREGEL, K. C. Heat shock proteins: modifying factors in physiological stress responses and acquired thermotolerance, Journal Applied Physiology, v. 92, p. 2177-2186, 2002.

KRUIP, T.A.M.; BONI, R.; WURTH, Y.A.; ROELOFSEN, M.W.M.; PIETERSE, M.C. Potential use of ovum pick-up for embryo production and breeding in cattle. Theriogenology, v. 42, p. 675-684, 1994.

KRUIP, T.A.M.; WENSING, T.; VOS, P.L.A.M. Characteristics of abnormal puerperium in dairy cattle and the rationale for common treatments. In: DISKIN, M.G. (Ed.), Fertility in the High Producing Dairy Cow. Occasional Publication No. 26. British Society of Animal Science, Edinburgh, p.63-79, 2001.

KUMAR TR, MATZUK MM. Gene knockout models to study the hypothalamus-pituitarygonadal axis. In: Shupnik MA (Ed.). Gene engineeing and molecular models in Endocrinology. Totowa, NJ: The Human Press, 2000.

LAMB, C. Entendendo os efeitos da nutrição na reprodução de vacas de corte. In: Curso Novos Enfoques na Produção e Reprodução de Bovinos, 7, 2003, Uberlândia. Anais... Uberlândia: UNESP, 2003. p.139-151.

LAMMOGLIA, M.A.; WILLARD, S.T.; OLDHAM, J.R. Effects of dietary fat and season on steroid hormonal profiles before parturition and on hormonal, cholesterol, triglycerides, follicular patterns and postpartum reproduction in Brahman cows. Journal of Animal Science, v.74, p.2253-2262, 1996.

LAMMOGLIA MA, WILLARD ST, HALLFORD DM., RANDEL RD. Effects of dietary fat on follicular development and circulating concentrations of lipids, insulin, progesterone, estradiol-17 $\beta$, 13,14-dihydro-15-keto-prostaglandin $\mathrm{F}_{2 \alpha}$ and growth hormone in estrous cyclic Brahman cows. Journal Animal Science, v.75, p.1591-1600, 1997.

LAMMOGLIA, M.A., R.A. BELLOWS, E.E. GRINGS, J.W. BERGMAN, R.E. SHORT and M.D. MACNEIL. 2000. Effects of dietary fat and sire breed on puberty, weight, and reproductive traits of F1 beef heifers. Journal Animal Science, 78: 2244-2252. 
LEROY, J. L. M. R.; VANHOLDER, T.; DELANGHE, J. R.; OPSOMER, G.; VAN SOOM, G.; BOLS, P. E. J.; DEWULFA, L.; KRUIF, A. Metabolic changes in follicular fluid of the dominat follicle in hight-yielding dairy cows early post partum. Animal Reproduction Science, v. 80, p. 201-2011, 2004.

LEROY, J. L. M. R.; OPSOMER, G.; VAN SOOM, A.; GOOVAERTS, I. G. F.; BOLS, P. E. J. Reduced Fertility in High-yielding Dairy Cows: Are the Oocyte and Embryo in Danger? Part I The Importance of Negative Energy Balance and Altered Corpus Luteum Function to the Reduction of Oocyte and Embryo Quality in High-yielding Dairy Cows. Reproduction Domestic Animal, v. 43, p. 612-622, 2008b.

LEROY, J. L. M. R.; VANHOLDER, T.; VAN KNEGSEL, A. T. M.; GARCIA-ISPIERTO, I.; BOLS, P. E. J. Nutrient prioritization in dairy cows early postpartum; Mismatch betweem metabolism and fertility? Reproduction Domestic Animal, v. 43, p. 96-103, 2008a.

LEURY, B.J.; MURRAY, P.J.; ROWE, J.B. Effect of nutrition on the response in ovulation rate in merino ewes following short-term supplementation and insulin administration.

Australian Journal Agricultural Research, v. 41, p. 751-759, 1990.

LEYENS, G.; KNOOPS, B; DONNAY, I. Expression of peroxiredoxins in bovine oocytes and embryos produced in vitro. Molecular Reproduction Development, v. 69, p. 243-251, 2004.

LIN, C.Y., McALLISTER, A.J., BATRA, T.R. et al. 1986. Production and reproduction of early and late bred dairy heifers. Journal Dairy Science, 69:760

LUCY, M. C. Mechanisms linking nutrition and reproduction in postpartum cows.

Reproduction Domestic Ruminant, v. 61, p. 415-417, 2003.

LUCY, M. C.; SAVIO, J. D.; BADINGA, L.; LA SOTA, R. L.; THATCHER, W. W. Factors that affect ovarian follicular dynamics in cattle. Journal of Animal Science, v. 70, p. 36153626, 1992.

LUCY, M. C. Regulation of ovarian follicular growth by somatotropins and insulin-like growth factors in cattle. Journal of Dairy Science, v. 83, p. 1635-1647, 2000.

LUSSIER, J.G.; MATTON, P.; DUFOUR, J.J. Growth rates of follicles in the ovary of the cow. Journal of Reproduction and Fertility, Cambridge, v. 81, p. 301-307, 1987.

MAREI, W. F.; WHATES, D. C.; FOULADI-NASHTA, A. A.: The effect of linolenic acid on bovine oocyte maturation and development. Biology of Reproduction, v. 81, p. 10641072, 2009.

MARQUES, C. C.; BAPTISTA, M. C.; VASQUES, M. I.; HORTA, A. E .M.; PEREIRA, R. M. Effect of polyunsaturated fatty acids (PUFA) on bovine oocyte in vitro maturation and subsequent embryo development and freezability. Reproduction of Domestic Animals, v. 109, p. 116, 2007. 
MARTIN, L.C.; BRINKS, J.S.; BOURDON, R.M. et al. Genetic effects on beef heifer puberty and subsequent reproduction. Journal of Animal Science, v.70, p.4006-4017, 1992.

MATOS MHT, LIMA-VERDE IB, LUQUE MCA, MAIA JR JE, SILVA JRV; CELESTINO JJH, MARTINS FS, BÁO SN, LUCCI AM, FIGUEIREDO JR. Essential role of follicle stimulating hormone in the maintenance of caprine preantral follicle viability in vitro. Zygote. v.15, p.173-182, 2007.

MATTON, P.; ADELAKOUN, V.; COUTURE, Y.; DUFOUR, J.J. Growth and replacement of the bovine ovarian follicles during the estrous cycle. Journal Animal Science, v. 52, p. 813-20, 1981.

MATTOS, R.; STAPLES, C.R.; ARTECH, A. et al. The effects of feeding fish oil on uterine secretion of PGF2, milk composition, and metabolic status of periparturient Holstein cows. Journal of Dairy Science, v.87, p.921-932, 2004.

MAURASSE, C.; MATTON, P.; DUFOUR, J.J. Ovarian follicular populations at two stages of an oestrus cycles given high energy diets. Journal of Animal Science, v. 61, p. 1194-1200, 1985.

MCBRIDE, B.W.; BERTHIAUME, R.; LAPIERRE, H. Nutrient flow in the lactating cow. Can. Journal Animal Science, v.78, suppl., p.91-104, 1998.

MCEVOY, T. G.; ROBINSON, J. J.; AITKEN, R. P.; FINDLAY, P. A.; PALMER, R. M.; ROBERTSON, I. S. Dietary-induced suppression of pre-ovulatory progesterone concentrations in superovulated ewes impairs the subsequent in vivo and in vitro development of their ova. Animal Reproduction Science, v. 39, p. 89-107, 1995.

MCEVOY, T. G.; SINCLAIR, K. D.; STAINES, M. E.; ROBINSON, J. J.; ARMSTRONG, D. G.; WEBB, R. In-vitro blastocyst production in relation to energy and protein intake prior to oocyte collection. Journal of Reproduction and Fertility, v. 19, p. 132, 1997 (Resumo).

MCEVOY, T. G.; COULL, G. D.; BROADBENT, P. J.; HUTCHINSON, J. S. M.; SPREAK B. K. Fatty acid composition of lipids in immature catle, pig and sheeo oocytes with intact zona pellucida. Journal of Reproduction and Fertility, v. 118, p. 163-170, 2000.

MCEVOY, T.G.; ROBINSON, J.J.; ASHWORTH, C.J.; ROOKE, J.A.; SINCLAIR, K.D. Feed and forage toxicants affecting embryo survival and fetal development. Theriogenology, v.55, p.113-129, 2001.

MELVIN, E.J.; LINDSEY, B.R.; QUINTAL-FRANCO, J.; ZANELLA, E.; FIKE, K.E.; VAN TASSELL, C.P.; KINDER, J.E. Circulating concentrations of estradiol, luteinizing hormone, and follicle stimulating hormone during waves of ovarian follicular development in prepubertal cattle. Biology of Reproduction, Madison, v. 60, p. 405-412, 1999. 
MENEGAZ, A. L.; LOBATO, J. F. P.; PEREIRA, A. C. G. Influência do manejo alimentar no ganho de peso e no desempenho reprodutivo de novilhas de corte. Revista Brasileira de Zootecnia, Viçosa,v.37, n.10, p.1844-1852, 2008.

MIES FILHO, A. Reprodução dos Animais e Inseminação Artificial, 4. ed. Porto Alegre, RS: Ed. Sulina, 1977, v. 1. 359 p.

MIHM, M.; GOOD, T.E.M.; IRELAND, J.L.H.; IRELAND, J.J.; KNIGHT, P.G.; ROCHE, J.F. Decline in serum follicle-stimulating hormone concentrations alters key intrafollicular growth factors involved in selection of the dominant follicle in heifers. Biology of Reproduction, Madison, v. 57, p. 1328-1337, 1997.

MOLLE, G.; BRANCA, A.; LIGIOS, S. Effect of grazing backround and flushing supplementation on reproductive performance in Sarda ewes. Small Ruminant Research, v. 17 , p. $245-254,1995$.

MOLLO, M. R.; RUMPF, R.; MARTINS, A. C.; MATTOS, M. C. C.; LOPES JR., G.; CARRIJO, L. H. D.; SARTORI, R. Ovarian function in Nelore heifers under low or high feed intake. Acta Scientiae Veterinariae, v. 35, p. 958, 2007 (Abstract).

MONTANHOLI, Y. R.; BARCELLOS, J. O. J.; BORGES, J. B.; COSTA, E. C.; WUNSH, C.; PRATES, E. R. Ganho de peso na recria e desempenho reprodutivo de novilhas acasaladas com sobreano. Pesquisa Agropecuária Brasileira, Brasília, v.39, n.12, p.1253-1259, 2004.

MORAN, C. et al. Puberty in heifers: a review. Animal Reproduction Science, v.18, p.167$182,1989$.

MOSELEY, W.M.; DUNN, T.G.; KALTENBACH, C.C.; SHORT, R.E.; STAIGMILLER, R.B. Negative feedback control of luteinizing hormone secretion in prepubertal beef heifers at 60 and 200 days of age. Journal of Animal Science, Savoy, v. 58, p. 145-150, 1984.

NAKADA, K. et al. Changes in response to GnRH on luteinizing hormone and follicle stimulating hormone secretion in prepubertal heifers. Journal of Reproduction and Development, v.48, p.545-551, 2002.

NEIVA, R.S. Produção de bovinos leiteiros. 2.ed. Lavras: UFLA : 2000. 514p.p.173-252, cap. 9.

NIBART, M.; SILVA PEIXER, M.; THUARD, J.M.; DURANT, M.; GUYADER-JOLY, C.; PONCHON, S.; MARQUANT-LE GUIENNE, B.; HUMBLOT, P. Embryo production by OPU and IVF in dairy cattle. In: Réunion A.E.T.E., XI, Hannover, Proceedings, p. 216, 1995.

NOLAN, R.; O'CALLAGHAN, D.; DUBY, R. T.; LONERGAN, P.; BOLAND, M. P. The influence of short-term nutrient changes on follicle growth and embryo production following superovulation in beef heifers. Theriogenology, v. 50, p.1263-1274, 1998. 
NOLLER, C.H.; MOE, P.W. Determination of NRC energy and protein requirements for ruminants. In: Simpósio internacional sobre exigências nutricionais de ruminantes, 1995, Viçosa. Anais... Viçosa, MG: JARD Ed., 1995. p.53-76.

NONATO JÚNIOR, I.; RUFINO, F. A.; SANCHES, B. V.; PONTES, J. H. F.; UVO, S.; ERENO JÚNIOR, J. C.; SENEDA, M. M. Produção de embriões em vacas Nelore com a utilização associada de FIV e TE. In: REUNIÃO ANUAL DA SOCIEDADE

BRASILEIRA DE TECNOLOGIA DE EMBRIÕES, 18., 2004, Barra Bonita. Resumos... Porto Alegre: UFRGS, 2004. v. 32. p. 95.

NRC - NATIONAL RESEARCH COUNCIL. Nutrient requeriments of dairy cattle. 7.rev.ed. Washington, D.C.: NRC, 2001. 381 p.

O’CALLAGHAN, D.; YAAKUB, H.; HYTTEL, P.; SPICER, L. J.; BOLAND, M. P. Effect of nutrition and superovulation on oocyte morphology, follicular fluid composition and systemic hormone concentrations in ewes. Journal of Reproduction and Fertility, v.118, p. 303-13, 2000.

OLDICK, B.S., C.R. STAPLES, W.W. THATCHER and P. GYAWU. 1997. Abomasal infusion of glucose and fat-effect on digestion, production, and ovarian and uterine functions of cows. Journal Dairy Science, 80: 1315-1328.

OLIVEIRA JR RC, PIRES AV, FERNANDES JR, SUSIN I, SANTOS FAP, ARAÚJO RC. Substituição total do farelo de soja por uréia ou amiréia, em dietas com alto teor de concentrado, sobre a amônia ruminal, os parâmetros sanguíneos e o metabolismo do nitrogênio em bovinos de corte. Revista Brasileira Zootecnia, v.33, p.738-748, 2004.

OLTNER, R.; WIKTORSSON, H. Urea concentration in milk and blood as influenced by feeding varying amounts of protein and energy to dairy cows. Livestock Production Science, Champaign, v. 10, n. 5, p. 457-467, 1983.

OLTNER R, EMANUELSON M, WIKTORSSON H. Urea concentration in milk in relation to milk yield, live weight, lactation numbers, and amount and composition of feed given to dairy cows. Livestock Prod Science, v.12, p.47-57, 1985.

PALMQUIST, D. L. Influence of source and amount of dietary fat on digestibility in lactating cows. Journal of Dairy Science, v. 75, n.4, p. 1354-60, 1991.

PATTERSON, D. J.;PERRY, R.C.; KIRACOFE, G.H.; BELLOWS, R.A.; STAIGMILLER, R.B.; CORAH, L.R. Management considerations in heifers development and puberty. Journal of Animal Science, v.70, p. 4018-4035, 1992.

PAYNE, J.M., DEW, S.M., MANSTON, R. et al. The use of metabolic profile test in dairy herds. The Veterinary Record. v. 87, p. 150-158, 1970.

PEREIRA, R.M.; CARVALHAIS, I.; PIMENTA, J.; BAPTISTA, M.C.; VASQUES, M.I.; 
PETIT, H. V. Digestion, milk production, milk composition, and blood composition of dairy cows fed whole flaxseed. Journal of Dairy Science, v. 85, p.1482-1490, 2002.

PETIT, H. V. Digestion, milk production, milk composition, and blood composition of dairy cows fed whole flaxseed. Journal of Dairy Science, v. 85, p.1482-1490, 2002.

PETIT, H. V.; DEWHURST, R. J.; SCOLLAN, N. D.; PROULX, J. G.; KHALID, M. W.; HARESIGN, W.; TWAGIRAMUNGU, H.; MANN, G. E. Milk production and composition, ovarian function, and prostaglandin secretion of dairy cows fed omega-3 fats. Journal of Dairy Science, v.85, p.889-899, 2002.

PETIT, H.V.; TWAGIRAMUNGU, H. Conception rate and reproductive function of dairy cows fed different fat sources. Theriogenology, v.66, p.1316-1324, 2006.

PETIT, H.V.; CAVALIERI, F.B.; SANTOS, G.T.D. et al. Quality of embryos produced from dairy cows fed whole flaxseed. Journal of Dairy Science, v.91, p.1786-1790, 2008.

PIERSON, R.A.; GINTHER, O.J. Follicular popilations during the estrous cycle in heifers. III Time of selection of the ovulatory follicle. Animal Reprod. Science, v. 16, p. 81-95, 1988.

PINHEIRO, O.L.; BARROS, C.M.; FIGUEREDO, R.A.; VALLE,; E.R. DO, ENCARNAÇÃO, R.O.; PADOVANI, C.R. Estrous Behavior and Estrous-toovulation interval in Nelore Cattle (Bos indicus) With Natural Estrous or induced With Prostaglandin F2 á or Norgestomet and Estradiol Valerato. Therigenology, v. 49, p. 667-681, 1998.

PIRLO, G.; CAPELLETTI, M.; MARCHETTO, G. Effects of energy and protein allowances in the diets of prepubertal heifers on growth and milk production. Jounal Dairy Science, v.80, p.730-739, 1997.

PONNAMPALAM, E. N.; SINCLAIR, A. J.; EGAN, A. R; BLAKELEY S. J.; LEURY, B. Effect of diets containing n-3 fatty acids on muscle long-chain n-3 fatty acid content in lambs fed low- and medium-quality roughage diets. Journal of Animal Science, v. 79, p.698-706, 2001.

RAES, K.; DE SMET, S.; DEMEYER, D. Effect of dietary fatty acids on incorporation of long chain polyunsaturated fatty acids and conjugated linoleic acid in lamb, beef and pork meat: a review. Animal Feed Science and Technology, v.113, p.199- 221, 2004.

RAMAKERS, C.; RUIJTER, J. M.; DEPREZ, R. H.; MOORMAN, A. F. Assumption-free analysis of quantitative real-time polymerase chain reaction (PCR) data. Neuroscience Letters, v. 339, p. 62-66, 2003.

RANDEL, R.D. Nutrition and postpartum rebreeding in cattle. Journal Animal Science, v.68, p.853-862, 1990. 
RHODES, F. M.; ENTWISTLE, K. W.; KINDER, J. E. Changes in ovarian function and gonadotropin secretion preceding the onset of nutritionally induced anestrus in Bos indicus heifers. Biology and Reproduction, v. 55, p. 1437-1443, 1996.

RICHARDS, M. W.; WETTEMANN, R. P.; SCHOENEMANN, H. M. Nutritional anestrus in beef cows: Concentrations of glucose and nonesterefied fatty acids in plasma and insulin in serum. Journal Animal Science. V. 67, p. 2354-2362, 1989.

RICHARDS, J.S.; RUSSELL, D.L.; OCHSNER, S.; et al. Novel signaling pattways that control ovarian follicular development, ovulation, and luteinization. Recent Progress in Hormone Research, v.57, p.195-220, 2002.

ROBINSON, J.J. Nutrition in the reproduction of farm animals. Nutrition Research Review, Cambridge, v.3, p. 253-276, 1990.

ROBINSON, T.; SHELTON, J. Reproduction in Cattle, In: CUPPS, P. Reproduction in Domestic Animals. 4ª Edicion. San Diego: Academic Press, p. 445-470, 1991.

ROBINSON P.H. Effect of yeast culture (Saccharomyces cerevisiae) on adaptation of cows to diets postpartum. Journal Dairy Science, v.80, p.1119-1125, 1997.

ROBINSON, R.S.; PUSHPAKUMARA, P.G.A.; CHENG, Z.; PETERS, A.R.; ABAYASEKARA, D.R.E.; WATHES, D.C. Effects of dietary polyunsaturated fatty acids on ovarian function in lactating dairy cows. Reproduction, v.124, p.119-131, 2002.

ROBINSON, J.J.; ASHWORTH, C.J.; ROOKE, J.A.; MITCHELL, L.M.; MCEVOY, T.G. Nutrition and fertility in ruminant livestock. Animal Feed Science and Technology, v.126, p,259-276, 2006.

ROSELER, D.K.; FERGUSON, J.D.; SNIFFEN, C.J.; HERREMA, J. Dietary protein degradability effects on plasma and milk urea nitrogen and milk nonprotein nitrogen in Holstein cows. Jouranl Dairy Science, v.76, p.525-534, 1993.

RUAS, J.R.M.; TORRES, C.A.A.; VALADARES FILHO, S.C.; PEREIRA, J.C.; BORGES, L.E.; MARCATTI NETO, A. Efeito da suplementação protéica a pasto sobre consumo de forragens, ganho de peso e condição corporal, em vacas Nelore. Revista Brasileira de Zootecnia, v. 29, n. 3, p. 930-934, 2000.

RUAS JRM, BORGES LE, MARCATTI NETO A, AMARAL R. Cria e recria de fêmeas F1: Holandês x Zebu para produção de leite. Inf Agropecuária, v.25, p.40-46, 2004.

RUBIN, K. C. P.; RIGO, A. G.; SCHROEDER, R. V.; SILVA, R. C. P.; MARQUES, M. O.; SENEDA, M. M. Avaliação de uma bomba de infusão contínua como geradora de vácuo para obtenção in vivo de oócitos bovinos. In: REUNIÃO ANUAL DA SOCIEDADE 
BRASILEIRA DE TECNOLOGIA DE EMBRIÕES, 18., 2004, Barra Bonita. Resumos... Porto Alegre: UFRGS, 2004. v. 32. p. 121.

RUTTER, L. M.; MANS, J. G. Hipoglycemia alters pulsatile and luteinizing hormone secretion in the postpartum beff cow. Journal Animal Science, v. 64, p. 479-488, 1987.

RYAN, D. P.; SPOON, R. A.; E WILLIANS, G. L. Ovarin follicular characteristics, embryo recovery and embryo viability in heifers fed hight fat diets and treated with folliclestimulating hormone. Journal Animal Science, v. 70, p. 3505-3513, 1992.

RYAN, D.P.; BAO, B.; GRIFFITH, M.K.; WILLIAMS, G.L. Metabolic and luteal squealed to heightened dietary fat intake in undernourished, anestrous beef cows induced to ovulate. Journal Animal Science, v.73, p.2086-2093, 1995.

SALLA, L.E.; FISCHER,; FERREIRA, E.X.; MORENO, C.B.; STUMPF, J.R.W.; DUARTE, L.D. Comportamento ingestivo de vacas Jersey alimentadas com dietas contendo diferentes fontes de gordura nos primeiros 100 dias de lactação. Revista Brasileira Zootecnia, v.32, p.683-689, 2003.

SANTOS, J.E.P. Efeitos da nutrição na reprodução bovina. In: Congresso Brasileiro de Raças Zebuínas, 3, 1998, Uberaba, MG. Anais... Uberaba: ABCZ, 1998. p.24-75.

SANTOS, J. E. P.E ALMSTALDEN, M. Effects of nutrition on bovine reproduction. XIII Reunião Annual SBTE. Atibaia, SP. In: Arq. Fac. Vet. UFRGS, Porto Alegre, RS, v. 26(1), p. 19-89, 1998.

SANTOS, J.E.P.; AMSTALDEN, M. Effects of nutrition on bovine reproduction. Arq. Fac., Vet. UFRGS, Porto Alegre, v. 26, n. 1., 19-89, 1998 (supl.)

SANTOS, E.S. Efeito do Pré-Tratamento com FSH ou BST, associado ao flushing nutricional, na resposta superovulatória em vacas Gir. Brasília/DF: FAV, 2002. 47p. Dissertação (Mestrado em Agronomia) - Faculdade de Agronomia e Medicina Veterinária /Universidade de Brasília.

SANTOS, J.E.P. Interação nutrição e reprodução da fêmea bovina. In: Grupo de Estudos de Nutrição de Ruminantes, 2005. Botucatu, SP: UNESP, 2005. Disponível em http://www.fca.unesp.br/nutrir/artigos/Interacaonutricao.pdf. Acessado em: 12 nov. 2005.

SANTOS, J. E. P.; RUTIGLIANO, H. M.; SÁ FILHO, M. F. Risk factors of resumption of postpartum estrous cycles and embryonic survival in lactating dairy cows. Animal Reproduction Science, v. 100, p. 207-221, 2009.

SANTOS, J.E.P.; CERRI, R.L.A.; SARTORI, R. Nutritional management of the donor cow. Theriogenology, v.69, p.88-97, 2008b. 
SILVA JRV, FIGUEIREDO JR. Influence of different concentrations of LH and FSH on in vitro caprine primordial ovarian follicle development. Small Ruminant Research, v.78, p.87-95, 2008.

SARTORI, R.; FRICKE, P. M.; FERREIRA, J. C. P.; GINTHER, O. J.; WILTBANK, M. C. Follicular deviation and acquisition of ovulatory capacity in bovine follicles. Biology of Reproduction, v. 65, p.1403-1409, 2001.

SARTORI, R.; ROSA, G. J. M; WILTBNAK, M. C. Ovarian strutucteres and circulating steroids in heirfers and lactating cows in summer and lactating and dry cows in winter. Journal of Dairy Science, v. 85, n. 11, p. 2813-2822, nov. 2002. Disnpnível em: http://www.ncbi.nlm.nih.gov/pubmed/12487448. Acesso em: 18 de nov de 2014.

SARTORI, R.; HAUGHIAN, J. M.; SHAVER, R. D.; ROSA, G. J.; WILTBANK, M. C. Comparison of ovarian function and circulating steroids in estrous cycles of Holstein heifers and lactating cows. Journal of Dairy Science, v. 87, p. 905-920, 2004.

SARTORI, R.; BASTOS, M. R.; BARUSELLI, P. S.; GIMENES, L. U.; ERENO, R. L.; BARROS, C. M. Physiological differences and implications to reproductive management of Bos taurus and Bos indicus cattle in a tropical environment. Society of Reproduction and Fertility, 2010.(In press).

SAS - STATISTICAL ANALYSIS SYSTEM. SAS user’s guide: statistics. Versão 8.0. Cary: SAS, 2000.

SATURNINO HM, AMARAL TB. Perspectivas para uso eficiente da interação nutriçãoreprodução em fêmeas bovinas de corte. In: Grupo de Estudos de Nutrição de Ruminantes, 2005. Botucatu, SP: UNESP, 2005. Disponível em:

http://www.fca.unesp.br/nutrir/artigos/Perspectivasfemeasbovinas.PDF. Acessado em: 12 nov. 2013.

SCARAMUZZI R. J.; MURRAY J. F. The nutrient requirements for the optimum production of gametes in assisted reproduction in ruminant animals. X $^{\circ}$ RÉUNION A.E.T.E. 1069-10 September 1994 - Lion (France), 85-103, 1994.

SCHILLO, K.K.; HALL, J.B.; HILEMAN, S.M. Effects of nutrition and season on the onset of puberty in the beef heifer. Journal Animal Science, Champaign, v. 70, n.12, p.3994-4005, 1992.

SCHULTZ, R. M. Regulation of zygotic gene activation in the mouse. Bio Essays, v. 15, p. 531-538, 1993.

SCOLLAN, N. D. ; DHANOA, M. S.; CHOI, N. J; MAENG, W. J; ENSER, M; WOOD, J. D.. Biohidrogenation and digestion of long fatty acids in steers fed on different sources of lipid. The Journal of Agricultural Science, v. 136, p. 345-355, 2001. 
SEJRSEN, K., PURUP, S. 1997. Influence of Prepubertal Feeding Level on Milk Yield Potential of Dairy Heifers: A Review. Journal Animal Science, 75:828-835.

SEMMELMANN, C.E.N. et al. Efeito de sistemas de alimentação no ganho de peso e desempenho reprodutivo de novilhas Nelore acasaladas aos 17/18 meses de idade. Revista Brasileira de Zootecnia, v.30, n.3, p.835-843, 2001.

SHORT, R. E.; ADAMS, D. C. Nutritional and hormonal interrelationships in beef cattle reproduction. Canadian Journal Animal Science, v. 68, p. 29-39, 1988.

SHORT, R.Y.; STAIMILLER, R.B.; BELLOWS, R.L. et al. Breeding heifers at one year of age: biological and economic considerations. In: FIELDS, M.J.; SAND, R.S. (Eds.) Factors affecting calf crop. London: CRC Press, 1994. p.55-68.

SILVA JRV. Growth factors in goat ovaries and the role of activina-A in the development of esrly-staged follicles. 142f. Thesis $(\mathrm{PhD})$ - Utrecht University, Faculty of Veterinary Medicine. 2005.

SILVA JR, VAN DEN HURK R, FIGUEIREDO JR. Expression of mRNA and protein localization of epidermal growth factor and its receptor in goat ovaries. Zygote, v.14, p.107117, 2006.

SILVA-SANTOS, K. C.; SANTOS, G. M. G.; SILOTO, L. S.; HERTEL, M. F.; ANDRADE, E. R.; RUBIN, M. I. B.; STURION, L.; MELO-STERZA, F. A.; SENEDA, M. M. Estimate of the population of preantral follicles in the ovaries of Bos Taurus indicus and Bos Taurus Taurus cattle. Therioogenology, v. 76, n. 6, p. 1051-7, 01 de out. 2011. Disponível em: http://www.ncbi.nlm.nih.gov/pubmed/21722949. Acesso em: 20 de julho de 2014.

SINCLAIR KD, MCEVOY TG, CAROLAN C, MAXFIELD EK, MALTIN CA, YOUNG LE, WILMUT I, ROBINSON JJ, BROADBENT PJ. Conceptus growth and development following the culture of ovine embryos in media supplemented with sera. Theriogenology, v.49, p.218, 1998.

SINCLAIR KD, KURAN M, GEBBIE FE, WEBB R, MCEVOY TG. Nitrogen metabolism and fertility in cattle: II. Development of oocytes recovered from heifers offered diets different in their rate of nitrogen release in the rumen. Journal Animal Science, v.78, p.26702680, 2000.

SIROTKIN AV, MAKAREVICH AV. Growth hormone can regulate functions of porcine ovarian granulosa cells through the cAMP/protein kinase A system. Animal Reproduction Science, v.70, p.111-126, 2002.

SNIFFEN, C.J.; O'CONNOR, J.D.; VAN SOEST, P.S.; FOX, D. G.; RUSSEL, J. B. A net carbohydrate and protein system for evaluating cattle diets. II. Carbohydrate and protein availability. Journal of Animal Science, v.70, n.11, p.3562-3577, 1992. 
SPICER, L. J.; CROW, M. A.; PRENDIVILLE, D. J.; GOULDING, D.; ENRIGHT, W. J. Sistemiv but not intraovarian concentrations of insuliln-like growth factor-I are affected by short-term fasting. Biology Reproduction. v. 46(5), p. 920-925, 1992.

STAPLES, C.R., W.W. Thatcher and J.M. Burke. 1996. Influence of supplemental fat on reproductive tissues of the dairy cow. Journal Dairy Science, 79: 1964-1978.

STAPLES CR, GARCIA-BOJALIL CM, OLDICK BS, THATCHER WW, RISCO CA. Protein intake and reproductive performance of dairy cows: a review, a suggested mechanism, and blood and milk urea measurements. In: Annual Florida Ruminant Nutrition Symposium, 4, 1993, Gainesville. Proceedings... Gainesville: University of Florida, 1993. p. 37-51.

STAPLES, C. R.; BURKE, J. M.; THATCHER, W. W. Influence of supplemental fats on reproductive tissues and performance of lactating cows. Journal of Dairy Science, v. 81, p.856-871, 1998.

STURNEY, R. G.; REIS, A.; LEESE, H. J.; MCEVO, T. G., Role of fatty acids in energy provision during oocyte maturation an early embryo development. Reproduction of Domestic Animals, v. 44, p. 50-58, 2009.

SUNDERLAND, S.J.; KNIGHT, P.G.; BOLAND, M.P.; ROCHE, J.F.; IRELAND, J.J. Alterations in intrafollicular levels of different molecular mass forms of inhibin during development of follicular- and luteal-phase dominant follicles in heifers. Biology of Reproduction, Madison, v. 54, p. 453-462, 1996.

TALAVERA, F., PARK, C.S., WILLIAMS, G.L. 1985. Relationships among dietary lipid intake, serum cholesterol and ovarian function in Holstein heifers. Journal Animal Science, 60(4):1045-1051.

THANGAVELU, G.M.; COLAZO, G.; AMBROSE, D.J. et al. Diets enriched in unsaturated fatty acids enhance early embryonic development in lactating Holstein cows.

Theriogenology, v.68, p.949-957, 2007.

THIBIER, M. Data Retrieval Committee Statistics of Embryo Transfer - Year

2007:THOMAS, M.G. AND G.L. WILLIAMS. 1996. Metabolic hormone secretion and FSHinduced superovulatory responses of beef heifers fed dietary fat supplements containing predominantly saturated or polyunsaturated fatty acids. Theriogenology, 45: 451-458.

THOMAS, M.G., B. BAO AND G.L. WILLIAMS. 1997. Dietary fats varying in their fatty acid composition differentially influence growth in cows fed isoenergetic diets. Journal Animal Science 75: 2512- 2519.

TRINDER, P. Determination of glucose in blodd using glucose oxidase with an alternative oxygen acceptor. Annals of Clinical Biochemistry, v. 6, n. 1, p. 24-26, 1969. 
TURZILLO, A.M.; FORTUNE, J.E. Suppression of the secondary FSH surge with bovine follicular fluid is associated with delayed ovarian follicular development in heifers. Journal of Reproduction and Fertility, Cambridge, v. 89, p. 643-653, 1990.

VALADARES FILHO, S. C.; MAGALHÃES, K. A.; ROCHA JÚNIOR, V. R. Tabelas brasileiras de composição de alimentos para bovinos. Viçosa, MG: UFV, 2006. 329p.

VAN DEN HURK R, ZHAO J. Formation of mammalian oocytes and their growth, differentiation and maturation within ovarian follicles. Theriogenology, v.63, p.1717-1751, 2005 .

VAN SOEST, P.J. Nutritional Ecology of the Ruminant. 2. ed. Cornell: Ithaca, 1994. 476p.

VARGAS, L.N.; LANA, R.P.; JHAM, G.N. et al. Adição de Lipídeos na Ração de Vacas Leiteiras: Parâmetros Fermentativos Ruminais, Produção e Composição do Leite. Revista Brasileira de Zootecnia, Viçosa, v. 31, (supl. 1), p. 522-529, 2002.

VIANA, J. H. M.; FERREIRA, A. M.; SÁ, W. F.; CAMARGO, L. S. A. Follicular dynamics in zebu cattle. Pesquisa Agropecuária Brasileira, v. 35, p. 2501-2509, 2000.

VIZCARRA, J. A.; WETTEMANN, R. P.; SPITZER, J. C.; MORRISON, D. G. Body condition at parturition and postpartum weight gain influence liteal activity and concentrarion on glucose, insulin and noesterified fatty acids in plasma of primaparous beef cows. Journal Animal Science. v. 76, p. 927-936, 1998.

WATHES, D.C.; ABAYASEKARA, D.R.E.; AITKEN, R.J. Polyunsaturated fatty acids inmale and female reproduction. Biology of Reproduction, v.77,p.190-201, 2007.

WEBB, R.; CAMPBELL, B. K.; GARVERICK, H. A.; GONG, J. G.; GUTIERREZ, C. G.; ARMSTRONG, D. G. Molecular mechanisms regulating follicular recruitment and selection. Journal of Reproduction and Fertility, v. 54, p. 33-48, 1999.

WEBB, R.; GOSTEN, R.G.; TELFER, E.E.; MOOR, R.M. Factors affecting folliculogenesis in ruminants. Animal Sciences, Savoy, v. 68, p. 257-284, 1999.

WEISS, W.P.; PINOS-RODRÍGUEZ, J.M.; WYATT, D.J. The value of different fat supplements as sources of digestible energy for lactating dairy cows. Journal of Dairy Science. v. 94, p. 931-939, 2011.

WETTEMANN, R. P.; LENTS, C. A.; CICCIOLI, N. H.; WHITE, F. J.; RUBIO, I. Nutritional- and suckling-mediated anovulation in beef cows. Journal of Animal Science, v. 81, p. 48-59, 2003.

WILLIAMS, G. L. Suckling as a regulator of postpartum rebreeding in cattle: a review. Journal of Animal Science, v. 68, p. 8331-852, 1990. 
WILLIAMS GL, STANKO RL. Dietary fats as reproductive nutraceuticals in beef cattle. Journal Animal Science, v.77, p.1-12. 1999.

WILLIAMS GL. Suplementação de gordura na dieta como estratégia para aumento da eficiência reprodutiva em bovinos. In: Curso Novos Enfoques na Produção e Reprodução de Bovinos, 5, 2001, Uberlândia, MG. Anais... Uberlândia: Conapec Jr; Botucatu: UNESP, 2001. p.95-101.

WILTBANK, J.N.; GREGORY, K.E.; SWIGER, J.E. et al. Effect of heterosis on age and weight at puberty in beef heifers. Journal Dairy Science, v.25, p.733-739, 1969.

WILTBANK, M. C.; LOPES, H.; SARTORI, R.; SANGSRITAVONG, S.; GUNTER, A. Changes in reproductive physiology of lactating dairy cows due to elevated steroid metabolism. Theriogenology, v. 65, p. 17-29, 2006.

WITTWER, F.; CONTRERAS, P. A. Consideraciones sobre el empleo de los perfiles metabólicos en ganado lechero. Archivos de Medicina Veterinaria, v.12, n.1, p.180-188, 1980.

WITTWER, F,; BOHMWALD, H.; CONTRERAS, P. A. Análisis de los resultados de perfiles metabolicos abtenidos en rebaños lecheros em Chile. Archivos Medicina Veterinária, v. 19, p. 35-45, 1987.

WITTWER, F. Marcadores bioquímicos no controle de problemas metabólicos nutricionais em gado de leite. In: GONZÁLEZ, F. H. D. BARCELLOS, J. O.; OSPINA, H. RIBEIRO, L. A. O. (Eds.) Perfil metabólico em ruminantes: Seu uso em nutrição e doenças nutricionais. Porto Alegre, Gráfica Universidade Federal do Rio Grande do Sul, 2000. p.5362.

WOLFE, M.W.; STUMPF, T.T.; ROBERSON, M.S.; KITTOK, R.J.; KINDER, J.E. Opioid and $17 \beta$ estradiol regulation of LH and FSH secretion during sexual maturation in heifers. Domestic Animal Endocrinology, v.8, n.4, p. 491-498, 1991.

WOLFENSON, D.; INBARA, G.; ROTHA, Z.; KAIMB, M.; BLOCHA, A.; BRAW-TAL, R. Follicular dynamics and concentrations of steroids and gonadotropins in lactating cows and nulliparous heifers. Theriogenology, v. 62, p. 1042-1055, 2004.

WOOLUMS, A.R.; PETER, A.T. Cystic ovarian condition in cattle: Part I Folliculogenesis and ovulation. Compendium of Continuing Education Article, v. 16, p. 935-43, 1994.

WRIGHT, P.; MALMO, J. Pharmacological Manipulation of Fertility. Appl Food Animal Practice, v. 8, p. 57-89, 1992.

WU, L.L.Y.; DUNNING, K.R.; YANG, X.; RUSSEL, D.L.; LANE, M.; NORMAN, R.J.; ROBKER, R. High-Fat Diet Causes Lipotoxicity Responses in Cumulus-Oocyte Complexes 
and Decreased Fertilization Rates. Endocrinology, Chevy Chase, v.151, n.11, p.5438-5445, 2010.

YAAKUB, H.; O’CALLAGHAN, D.; DUFFY, P.; DUBY, R. T.; BOLAND, M. P. Effect of concentrate type and quatity on superovulation in cattle. Proceedings of Techniques for gamete manipulation and storage. Hamilton, New Zeland, p.37, 1996.

YAAKUB, H.; O'CALLAGHAN, D.; BOLAND, M.P. Effect of type and quantity of concentrates on superovulation and embryo yield in beef heifers. Theriogenology, v. 51, p. 1259-1266, 1999.

ZEITOUN, M. M.; RODRIGUEZ, H. F.; RANDEL, R. D. Effect of season on ovarian follicular dynamics in Brahman cows. Theriogenology, v. 45, p. 1577-1581, 1996.

ZERON, Y.; SKLAN, D.; ARAV, A. Effect of polyunsaturated fatty acid supplementation on biophysical parameters and chilling sensitivity of ewe oocytes. Molecular Reproduction and Development, v. 61, p. 271-278, 2002. 